\title{
Thermal Performance of a Buried Nuclear Waste Storage Container Storing a Hybrid Mix of PWR and BWR Spent Fuel Rods
}

\author{
G.i. Johnson
}

Manuscript Date: August 1989

Publication Date: November 1991

This is an infermal n port intended primarily for internal or limited extema! distributina. The opisions and conelasions stated are those of the anthar and may or miny not be those of the Laboratory.

Work Ferformed ander the anspices of the L.S. Department of Energy by the Lawtence Livernore National Laboratory ander Contract W.7w05-Eng-40. 


\section{DISCL $\neg$ IMER}

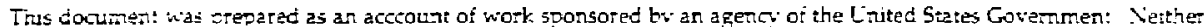
the Lrited Sta:es Government nor the Lniversity of Calionsa nor any of their emplovees. makes any warnanty

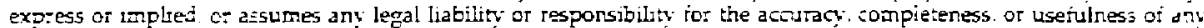

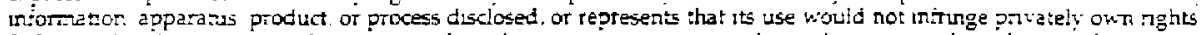

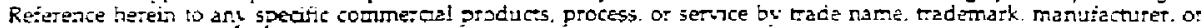

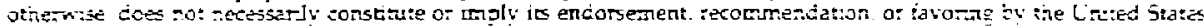

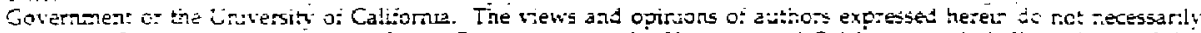

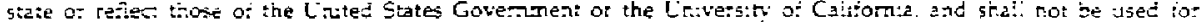

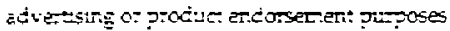

Tins report has deer reproducec duetiy: tor: the bes: a vailabie cop:

Arailable to DOE and DOE contractors from the Otice of Soentitc and Technicel luiormation P.O. Box 62. Oak Ridge. TN 37531

Paces avatlable from: $16 ! 31$ 5\%6-8-40T. FIS 626-3401

Arailable to the puble from the Sattonal Technical iniormator. Servee

U.5. Departsnent of Commerce 5285 Por Rovial Rd Sprngigele VA 2216t 
UCID--21414-Rev. I

DE92 004466

THERMAL PERformance of a

BUAIED NUCLEAR MASTE STORAGE CONTAINER

STORING A HYBRID NIX OF PWR AND BWR SPENT FUEL RODS

\author{
Gary L. Johnson \\ Thermo-fluids Group \\ Nuclear Test Engineering Division
}

August 1989 


\section{TABLE OF CONTENTS}

Ieple

Summary

L Introduction

IL. Thermal Models

Goometry

Thermal Load

Material Properties

Initial and Boundary Conditions

Analysis Codes

lil. 3-D Anałysis Results

IV. 2-D Anatysis Results

v. Conclusions

References

Tables

Appendix A
Page

14

15

21

34

69

73

76

96 


\section{LIST OJF FIGURES}

Page

Figure 1a. Geomeiry model used for 3-D analysis of the tuff has adiabatic boundaries at 4 and $15 \mathrm{~m}$ from the comtainer axis

Figure 1b Geometry model used for 2-D analysis of container cross section assumes uniform power generation in the PWR and BWR fuel canisters over length of the container

Figure 2a. Finite element model used for 3-D analysis of tuff (coarsely zoned model used for the 3-D Reference Case)

Figure 2b. Finite element model used for 2-D analysis of container for the cases without gas fill elements

Figure 2c. Finite element inodel used for 2-D analysis of container for the cases with gas fill elements

Figure 3. The peak temperature of the borehole wall for the 3-D reference case equals $204^{\circ} \mathrm{C}$ at $18 \mathrm{yr}$ atter enplacement and remains above $970^{\circ} \mathrm{C}$ for the entire $1000 \mathrm{yr}$

Figure 4. The heat flow in the tutt is one-dimensional above about 20 borehole diameters from the container midplane

Figure 5. The predicted peak temperature of the borehcle wall is $7 \circ \mathrm{C}$ hotter for the f.e. model with refined zoning and time step length than tor the 3-D relerence case with its coarser zoning and time step

Figure 6. The near-field temperature gradient in the tufl increases somewhat in the case with the refined zoning and time step length 


\section{LIST OF FIGURES (cont'd.)}

Page

Figure 7. The peak temperature of the berehole wall for the f.e. model with 5-year-old fuel nears $250^{\circ} \mathrm{C}$ at about $1 \mathrm{yr}$ after emplacement. The tuff at $1 \mathrm{~m}$ never exceeds $200^{\circ} \mathrm{C}$

Figure 8. The near-field temperature gradient in the tuff at the time of peak borehole wall temperature is very large

Figure 9. The predicted temperature of the tuff depends on the boundary condition at the earth's surface only at times nearing $1000 \mathrm{yr}$

Figure 10. Differerices in thermal pertormance between the $350 \mathrm{~m}$ case and the $700 \mathrm{~m}$ case only become noticeable after $800 \mathrm{yr}$. Isotherms for the $700 \mathrm{~m}$ case show that the heat flow is nearly symmetric about the container's centerplane

Figure 11. Storing 10-yr-old fuel at a 1.73:1 consolidation with the $15 \times 126 \mathrm{ft}$ spacings defined in the SCP results in a peak borehole wall temperature to $237^{\circ} \mathrm{C}$

Figure 12. The peak temperature of the ruel cladding for the $3045 S$ structure case is $323^{\circ} \mathrm{C}$. It occurs at about $3 \mathrm{yr}$ after emplacement

Figure 13. Isotherms for the 304 SS case at about 3 yr after emplacement show the peak cladding temperatures occur near the center of the leftmost PWR and central BWR tuel canisters

Figure 14. The peak temperature of the fuel cladding for the 7030 structure case, $3250 \mathrm{C}$, occurs about 3 yr after emplacement 


\section{LIST OF FIGURES (cont'd.)}

\section{Page}

Figure 15. Isotherms for the 7030 case at about 3 yr after emplacement show the central BWR canister is much cooler than the 304SS case

Figure 16. The peak temperature of the tuel cladding for the IN825 structure case (2-1) Reference Case) is $336^{\circ} \mathrm{C}$

Figure 17. Isotherms for the IN825 case at about 3 yr after emplacement

Figure 18. The surface temperature of the comtainer may vary by as much as $10^{\circ} \mathrm{C}$ between adjacent hot and cool spots

Figure 19. The effect of structural material choice is small, indicating that most of the heat is transferred to the shell by thermal radiation

Figure 20. The peak temperature of the fuel cladding for the loose backfill case is $391^{\circ} \mathrm{C}$ cccurring about $5 \mathrm{yr}$ after emplacement

Figure 21. Isothems for the loose backfill case at about $4 \mathrm{yr}$ after emplacernent

Figure 22. The peak temperature of the fuel cladding for the firm backtill case is $341^{\circ} \mathrm{C}$, occurring about 4 yr after emplacement

Figure 23. Isotherms for the firm backfill case at about $5 \mathrm{yr}$ after emplacement 


\section{LIST OF FIGURES (cont'd.)}

Page

Figure 24. Backfilling the annulus with loosely packed bentonite raises the peak temperatures over $50^{\circ} \mathrm{C}$ above the case with no backfill. Backfilling the annulus with firmly packed bentonite only raises the peak temperatures by about $5^{\circ} \mathrm{C}$

Figure 25. Using realistic contact thermal resistances rather than ideal values does not change the peak temperatures

Figure 26. The peak temperature of the fuel cladding for the 5-year fuel case, $411^{\circ} \mathrm{C}$, occurs about 8 months after emplacement

Figure 27. Isotherms for the 5-year tuel case at about 8 months atter emplacement

Figure 28. The peak temperature of the fuel cladding for the emissivity case with its lower emissivity on the inside surfaces is $346^{\circ} \mathrm{C}$

Figure 29. Isotherms for the emissivity case near the time of peak temperature show shaper gradients in structure than in the reference case

Figure 30. When compared with the reference case, the peak temperatures increase by as much as $10^{\circ} \mathrm{C}$ by assuming the lower emissivity for the inside surfaces

Figure 31. The peak temperature of the fuel cladding for the case with increased fuel conductivity is $322^{\circ} \mathrm{C}$

Figure 32. Isotherms for the fuel conductivity case show nuch less temperature gradient in the fuel boxes 


\section{LIST OF FIGURES (cont'd.)}

Page

Figure 33. The use of fuel pack thermal conductivities derived from Battelle's measured fuel bundle temperature profiles, lowers the peak cladding temperatures by 8 to $15^{\circ} \mathrm{C}$

Figure 34. The peak temperature of the fuel cladding for the gas fill case is $335^{\circ} \mathrm{C}$. Thermal radiafion is still the predominant heat transfer mode

Figure 35. Isotherms for the gas fill case at about 3 yr after emplacement

Figure 36. The peak temperature of the fuel cladding for the "best model" analysis, including: fine-zored mesh of tuff, improved fuel conductivity, 0.5 internal surface emissivity, and gas-fill conduction, is $336^{\circ} \mathrm{C}$

Figure 37 Isotherms for the best model analysis at about $3 \mathrm{yr}$ after emplacement

Figure 38. The peak temperature of the tuel cladding for the SCP layout case, with its $28 \%$ decrease in repository area per borehole and $15 \%$ decrease in thermal load, is $335^{\circ} \mathrm{C}$

Figure 39. Isotherms for the SCP layout case at about $4 \mathrm{yr}$ after emplacement

Figure 40. The best model thermal analysis of the container shows that the hybrid-loaded container satisfies the thermal design criteria ... 


\section{LIST OF TABLES}

Iitle

Page

TABLE 1: $10 \mathrm{yr}$, BWR and PWR Spent Fuel Thermal Output

5 yr, BWR and PWR Spent Fuel Thermal Output

TABLE 2: Tuff and Bentonite Material Thermal Properties

IN825 Material Thermal Properties

BWR and PWR Fuel Material Thermal Properties

BWR and PWR Fuel Material Thermal Properties[Case 8]

Air Material Thermal Properties

TABLE 3: "Convective" Boundary Conditions in Open Annulus

TABLE 4: Themal Analysis Cases/3-D Finite Element Model

92

Thermal Analysis Cases/2-D Finite Element Model

TABLE 5: Temperature Results Synopsis/3-D Analyses

93

Temperature Results Synopsis/2-D Analyses

94

TABLE 6: Thermal Loads From Possible Container Contents 


\section{Abstract}

Lawrence Livermore National Laboratory will design, model, and test nuclear waste packages for use at the Nevada Nuclear Waste Storage Repository at Yucca Mountain, Nevada. One such package would store tightly packed spent fuel rods from both pressurized and boiling water reactors. The storage container provides the primary containment of the nuclear waste and the spent fuel rod cladding provides secondary comtainment. A series of transient conduction and radiation heat transier analyses was run to determine for the first $1000 \mathrm{yr}$ of storage if the temperature of the tuff at the borehole wall ever falls below $97 \mathrm{c}$. and whether the cladding of the stored spent fuel ever exceeds $350^{\circ} \mathrm{C}$. Limiting the borehole to temperatures of $97^{\circ} \mathrm{C}$ or greater helps minimize corrosion by assuring that no condensed water collects on the container. The $350^{\circ} \mathrm{C}$ cladding limit minimizes the possibility of creeprelated failure in the spent fuel rod cladding. For a series of packages stored in a $8 \times 30 \mathrm{~m}$ borehole grid where each package comtains 10-yr-old spent fuel rods generating $4.74 \mathrm{~kW}$ or more, the borehole wall stays above $970 \mathrm{C}$ for the full 1000 -yr analysis period. For the $4.74-\mathrm{kW}$ load, the peak cladding temperature rises to just below the $350^{\circ} \mathrm{C}$ limit about 4 years after emplacement. If the packages are stored using the spacing specified in the Site Characterization Flan (15 ft $\times 126 \mathrm{ft}$ ), a maximum of $4.1 \mathrm{~kW}$ per container may be stored. If the $0.05-m$-thick void between the container and the borehole wall is filled with loosely packed bentonite, the peak cladding temperature rises more than $40^{\circ} \mathrm{C}$ above the allowed cladding limit. In all cases the dominant heat transfer mode between container components is thermal radiation. 


\section{SUMMARY}

Researchers in the Yucca Mountain Project (YMP) are designing containers for the long-term disposal of spent nuclear fuel and high-level radioactive waste. The proposed site of this repository is above the water table in the volcanic tuff under Yucca Mountain, Nevada. Lawrence Livermore National Laboratory (LLNL) is responsible for designing, modeling, and testing the waste containment barriers. Data from these efforts will be incorporated in the tinal waste package designs and specifications. One such preliminary design involves the tightly packed storage in metal containers of a combination of spent fuel rods from both boiling water reactors (BWR) and pressurized water reaciors (PWR). Consolidating the waste in fewer containers can minimize the number of packages in the repository. However, groups of consolidated waste containers, with their higher thermal loads, would be exposed to higher temperatures than those containing unconsolidated waste. Thus, it is imperative to determine the limit on the thermal pertormance under these increasedload operating conditions.

This report documents the results of a series of transient conduction and radiation heat-transfer analyses to predict the thermal response of both the container design and also the nearby tuff around the borehole where the container is emplaced. Specifically, these thermal analyses predict if the temperature of the tuff at the borehole wall will fall below $97^{\circ} \mathrm{C}$ and if the peak temperature of the spent fuel cladding will exceed $350^{\circ} \mathrm{C}$. The $97^{\circ} \mathrm{C}$ borehole limit is set to mirimize corrosion of the container shell by assuring that no condensed water collects on its outer surface. The container provides the primary containment for the radioactive material. Limiting the spent fuel rod cladding to $350^{\circ} \mathrm{C}$ or less will minimize creep-related iailure, thus improving secondary containment of the radioactive fuel.

The heat transfer analyses involve two geometric models, i.e., a threedimensional (3-D) model predicting the thermal response of the iuff surrounding the borehole subjected to the total thermal load from the waste storage container and a two-dimensional (2-D) model predicting the thermal response of a mean cross section of the container with its individual heat-generating fuel storage canisters. The borehole wall temperatures predicted by the 3-D analyses define the thermal sink conditions for the 2-D analyses. These analyses quantify the relative effects on 
thermal performance of (a) the thermal leads from the decay heat of the container contents, (b) the container structural materiais, (c) filling the annulus between container and borehole wall with bosely or firmly packed bentonite, and (d) the model for heat transfer inside the container. The analytic effort culminates in a best model thermal analysis to define the response of the container under a probable designlimiting thermal load.

For this work the geometric model assumes that a large number of 0.711 -m-diam containers are buried $350 \mathrm{~m}$ below the surface of the earth in $0.812-m$-diam $\times 4.5$-m-long vertical boreholes amanged in rows down the center of drift tunnels. Boreholes in the simulated region of the repository are spaced on $8-m$ centers along the drift and on 30-m centeis between drifts. This spacing is taiger than that defired by the repository's Site Characterization Plan' (SCP) since fewer boreholes would be needed. An additional study looked at the container/borehole response with SCP spacing and an equivaient hoat outpurt.

If the container being analyzed is surrounded by equivalently loaded containers emplaced at about the same time, each container in the array deposits its heat into a section of turi $8 \times 30 \times 700 \mathrm{~m}$. It is assumed that no heat is ierroved by ventilation in the dritt tunnels or by evaporation of the moisture in the tuff. Previous studies have stown that, for the 1000-yr analysis period, the tuff below the assumed $700-\mathrm{m}$ maximum interaction depth is relatively unaffected by the container thermal load. The thermal behavior at $700-\mathrm{m}$ predicted by this study also verities this assumption.

The thermal output of the contents of the container represents a hybrid load containing 4 canisters of spent BWR fuel and 3 canisters of spent PWR fuel. At the reactor facility, each fuel canister is packed with two assembiles of BWR and PWR spent fuel rods (called 2:1 at-reactor-consolidation). Also both the BWR and PWR spent fuel rods contain nomally enriched fuel and were used in the reactor for the normal 7.5-yr power generation period (called nomal burnup fuel). For most anajyses, both fuels are assumed to have been stored outside of the reactcr for $10 \mathrm{yr}$ at the time of emplacement in the borehole. At the time of emplacement. the total power autpur of the container with 10 -yr-old fuel is $4740 \mathrm{~W}$. The local power density (LPD) at emplacement, based on the local botehole spacing, is $80 \mathrm{~kW} / \mathrm{acre}$. Because these highty loaded packages will realiy only be used at a few selected locations in 
the repository, an areal power densty (APD) for the whole repository based on this power output has little meaning.

For the emplacement of this hybrid-filled container surrounded by an infinite ariay of equivalently loaded containers on $8 \times 30 \mathrm{~m}$ spacings, the following conclusions result from a review of the analyses documented herein. For a $4.74-\mathrm{kW}$ load or greater, the borehole wall stays above $97^{\circ} \mathrm{C}$ for the full $1000-y r$ analysis period. The iuff $1 \mathrm{~m}$ in from the borehole wall never exceeds $200^{\circ} \mathrm{C}$, even if the $10-y \mathrm{r}-$ old fuel is replaced with an equivalent weignt of 5-yr-old fuel. Because the borehole wall suriace temperature nears $200^{\circ} \mathrm{C}$, it is possible that the floor of the drift tunnel near these containers might surpass the $50^{\circ} \mathrm{C}$ maximum temperature allowable under general repository manned-use design criteria. Previous studies, modeling the effect ai drit iunnel, have shown 5 to $10^{\circ} \mathrm{C}$ decreases in borehole wall temperature due to ventilation.

For all but two cases, the peak cladding temperature remains below. put near, the $350^{\circ} \mathrm{C}$ limit. The best model analysis gives a peak cladding temperature of $336^{\circ} \mathrm{C}$. The two cases that do not satisty the maximum cladding temperature limi requirement (i.e., (1) replacing the 10-yr-old fuel with an equivalent weight of 5-yr-old fuel and (2) backfiling the 0.05-m-thick annulus between the container and the borehole wall with looseiy packed bentonite) at the $4.74-\mathrm{kW}$ power output results in peak cladding :Emperatures about $40^{\circ} \mathrm{C}$ to $60^{\circ} \mathrm{C}$ hotter than the maximum allowable. Packing the benionite firmly in the annulus, with its resultant increase in thermal conductivity over the loose pack, gives in a peak cladding temperature of $341^{\circ} \mathrm{C}$. The highly sensitive nature of these resuits to the assumed thermal properties of the backfill makes use of accurately measured values of these propenies crucial to further analyses guiding backfill design decisions.

Some generai comments can be added to these specific conclusions. For borenoles with no backfili, heat balance calculations on meat transierted from the contaner to the borehole wall show that thermal radiation causes most of the heat flow. That radiative heat transier is also the dominant mode inside the container is demonstrated by the resuits from three of the anaiyses: (1) The small effect on preaicted peak cladding temperatures of the conductivity of the container assembly siructural material. (2) The minor decrease in peak cladorr.g temperature resulting 
from modeled heat transfer by conouction through the gas fill. (3) The obvious sensitivity of the predicted temperatures to the value of the surface emissivity for the surfaces inside the container. Including the effect of heat iransfer from riatural convection in the cavities between the fuel canisters and the inner surface of the container shell would make the gas-fill model contribution more significant. The assumed value of the "effective" thermal conductivity for the "homogenized" fuel rocis/fuel canister assembly is the other main parameter that strongly affects predictions of peak cladding temperatures. This thermal property should also be accurately determined for all load conditions to assure reaistic precictions of the cladding temperatures.

On the basis of these conclusions and an overa!l view of the repository layout and expected container emplacement history, I make the following recommendations for additional thermal performance evaluations.

a. Establish accurate values for the effective thermal conductivity of the homogenized fuel canisters for all possibla fuel paciking configur :ons. Determine the relationship between the actual peak cladding tempe ature and that predicted by the homogenized model.

5. Add natural convection in the gas fill to the internal-heat-transter modal of the vertical containei.

c. Determine the surface emissivity of the tuff and the materials to be used in the waste package designs for various expected surface conditions.

d. Establish more accurate values ior the thermal conductivity of potential container backfills at various densities.

e. Using a best model complete a 3-D analysis of the venical container including axial variations in power output, material geometries. and thermal properties. 
f. Do transient, 3-D thermal analysis of various combinations of emplaced packages and emplacement histories for whole sections of the repository using the planned waste delivery scenario (e.g., Ref. 2).

g. Model the effect of the drift tunnels in detail, including the drift tunnel geometry and its associated humidity and heat removal by ventilation.

h. Establish sensitivity of resulis to each of the major model parameters for the range of values and the uncertainty of each of these parameters. 


\section{Irstroduction}

The Yucca Mountain Project (YMP) is part of the U.S. Department of Energy's Civilian Radioactive Waste Management Program. The Waste Package task of the YMP will design containers for the disposal of spent fuel and high-level waste in a repository. The proposed site for the reposit:y is in the unsaturated zone of the volcanic tuff under Yucca Mountain, which is located at the DOE Nevada Test Site. Lawrence Livermore Natienal Laboratory (LLNL) is responsible for designing, modeling, and lesting the waste containment barriers. These designs will be incorporated in the final waste package designs and specifications. The tinal barrier system design will be some combination of a waste form, container, borehole liner. borehole and drift backtill, and the near-field host rock. Engineering this barrier system will require an analyses to predict the thermal pe:formance of the design.

Information produced by the thermal analyses of the container and the nearfield host rock may be used to:

1. Demonstrate that the waste form or the near-field host rock will not exceed the maximum allowable temperatures set by phenomena affecting containment: i.e., thermal strain in the host rock, container corrosion, spent fuel cladding creep.

2. Calculate the approximate time periods of humid air and water contact with the waste package.

3. Provide temperature-time histories for material selections, corrosion testing, and release rate testing.

4. Provide component temperatures tor transportation, handling, storage, and retrieval while in the repository in order to determine ventilation, seal, etc. requirements.

Previous thermal studies by LLNL have reviewed the thermal performance of various conceptual container designs, their waste loads, and storage conditions. ${ }^{3-7}$ (See Appendix $A$ for a list of additional LLNL-internal documentation.) One proposed 
design involves the tightly packed storage of a combination of spent fuel rods from both boiling water reactors (EWR) and pressurized water reactors (PWR) in a vertically stored container. The thermal performance of a container with this type of load was expected to operate near the upper temperature limits allowed for long-term storage of this fuet form.

This report documents the results of a series of transient conduction and radiation heat-transfer analyses on a vertically stored nuclear waste storage container containing a hybrid mix of PWR and BWR spent fuel rods. The container will be buried in a borehole deep in the earth in volcanic tuft. The heat transfer analyses are separated into two parts: 3-D analyses modeling the thermal response of the tuff, and 2-D analyses modeling the thermal response of a cross section of the container. The 3-D analyses of the tuff use the total thermal contents of the container to determine the temperature-time history of the borehole wall. This history is then used as a temperature boundary condition for the 2-D analyses of the container. The temperature-time histories are determined up to $1000 \mathrm{yr}$ after emplacement in the storage borehole.

These analyses quantify the relative effects on thermal performance of (a) the thermal loads from the decay heat of the container contents. (b) the container structural materials, (c) the annulus between container and borehole wall filled with loosely or firmly packed bentonite, and (d) the model for heat transfer inside the container. The analytic efiort culminates in a best model thermal analysis to define the response of the container with a design-limiting thermal load. The effect of container orientation is left to a later study. As with most analytic efforțs, model improvements in terms of material property choices and important modes of heat transfer became more apparent as the effort progressed. Documentation of the effects of each change is referenced to an early model. Thus, for all but the best model analysis, the temperaiures are used more for relative comparisons with the appropriate reference cases (Case 1a/3-D:coarse mesh or Case 3/2-D:iN825) rather than as absolute magnitudes.

As performance evaluations, these thermal analyses determine if the predicted temperature of the tuff at the borehole wall ever falls below $97^{\circ} \mathrm{C}$ or if the predicted peak temperature of the PWR or BWR fuel cladding ever exceeds $350^{\circ} \mathrm{C}$. The 
borehole wall temperature limit is set to minimize corrosion of the primary containment barrier by assuring that no condensed water collects on the container. At the altitude associated with the $350 \mathrm{~m}$ burial depth below Yucca Mountain, water condenses at $97^{\circ} \mathrm{C}$. The $350^{\circ} \mathrm{C}$ spent fuel rod cladding limit is set to minimize creep in the fuel rod's cladding which provides secondary containment of the radioactive material'. An additional sheck determines if the tuff temperature $1 \mathrm{~m}$ in from the borehole wall exceeds $200^{\circ} \mathrm{C}$. This helps avoid stresses in the tuff from the mineral crystobalite dispersed in the tuff which changes phase and expands by $5 \%$ between $200{ }^{\circ} \mathrm{C}$ and $250^{\circ} \mathrm{C} .8$

The remainder of this document will discuss the models of the host rock and the container in terms of the geometry, thermal loads, material properties, and initial and boundary conditions. The results are compared with the appropriate reference case and the YMP program-defined performance limits. The report concludes with a summary of the results and conclusions and a list of suggestions for further analytic efforts to support definition of repository and container design criteria. 


\section{Thermal Models}

\section{Geometry}

The heat-transfer analyses are separated into two parts: 3-D analyses modeling the themal response of the tuff subjected to the total thermal load from the waste storage container and 2-D analyses modeling the thermal response of a mean cross section of the container. The geometry of the borehole is documented in Figure 1a.9-11 The 0.711-m-diam $\times 3.66-\mathrm{m}$-long container is buried $350 \mathrm{~m}$ below the surface of the earth in a 0.812 -m-diam $\times 4.50$-m-long vertical borehole. Boreholes in the simulated region of the repository are spaced on $8-\mathrm{m}$ centers along the drift and on $30-\mathrm{m}$ centers between drifts. This spacing is larger than the $15 \times 126 \mathrm{ft}$ spacing $(4.6 \times 38.4 \mathrm{~m})$ defined in the SCP because fewer boreholes would be needed for storage of hybrid-loaded containers storing 1.4 times the 3300-W SCP reterence thermal load. These hybrid-loaded waste storage packages contain seven spent fuel canisters located in compartments separated by structural supports. One final analysis will determine the hybrid-mix thermal load stored on SCP borehole spacings which gives a thermal response equivalent to $4740-W$ loaded containers stored on $8 \times 30 \mathrm{~m}$. spacings.

The thermal analyses assume that the container being modeled is surrounded by an infinite array of similarly loaded and spaced containers emplaced on the same date. is heat is removed by ventilation in the dritt tunnels or by evaporation of the moisture in the tuff. Heat from the container load flows primarily upwards toward the a abient-cooled earth's surface as well as downward tcward the canter of the earth. I chose to model only the first $350 \mathrm{~m}$ of the downward flow because previous analyses have indicated that the heat wave from the source barely reaches $350 \mathrm{~m}$ from the source after the first $1000 \mathrm{yr}$. Thus, each container dumps its heat into a section of tuit $8 \times 30 \times 700 \mathrm{~m}$. For the 3-D analyses this results in adiabatic heat transfer conditions on planes midway between boreholes (i.e., at 4 and $15 \mathrm{~m}$ from the container centerline). These adiabatic planes are normal to the respective 8 - and $30-\mathrm{m}$ dimensions. Eanier studies determined that the heat flow in the tuff near the borehole is approximately symmetric about the container's horizontal midplane. Thus, for all but one 3-D case, I only modeled the $350 \mathrm{~m}$ of the tuff between the container midplane and the earth's surface. The primary 3-D finite element (f.e.) model used in these 
aralyses is one-eiginth of the container and its asseciated tuff. The one-eighth section is bounded by the earth's surface, the container midplane, the adiabatic planes between adjacent boreholes, and the vertical planes through the container axis, which are parallel to these adiabatic planes. Figure $2 a$ shows one f.e. mesh for this $3-D$ model.

Another 3-D model quantifies the effect of modeling both the $350 \mathrm{~m}$ above the container midplane and the $350 \mathrm{~m}$ below. One additional 3-D model investigates the effect of a refined mesh zoning and decreased calculational time step size. This model uses twice the reference model's number of divisions along the $350 \mathrm{~m}$ dimension and half the calculational time step size. A follow-on stuoy using even tiner finite-element model zoning will define the mesh that gives a zoning-independent teriperature distribution.

The 2-D f.e. model uses the geometry of an average cross section of the container centered in the borehole. The geometry of the container is documented in Figure 1b. Perturbations in response due to non-concentric emplacement are to be considered in later studies. The smatl distortions of the comers of the central BWR fuel canister outline were made for ease of heat-transfer modeling. For minimized computer costs and ease of modeling, the reference 2-D f.e. model has no elements to represent heat transfer in the coniainer's gas fill. Figure $2 b$ shows the f.e. mesh for this model. Three additional 2-D cases were run to model heat conduction through the gas fill between the fuel cans, the support structure, and the container shell (Figure 2c). Natural convection in the gas fill was not modeled because no good heat transfer correlation was found for the cavity geometry being modeled. Cases involving backfill outside the container have additional elements to model heat conduction througn this backfill.

Analyzing a 2-D planar cross section of the container is acceptable for these perametric studies because of the relatively uniform distribution of the thermal load and the large length-to-diameter ratio. Eventually, because of the axial vs radial variations in the heat transfer in an actual container, a 3-D analysis of the containes will be necessary. 


\section{ThermalLoad}

The power density distribution alonig the container's centerline varies trom a volumetric-average value. However, its variation is sufficiently small that, for easier analysis, the present work uses the average condition in a 2-D model.

The thermal output of the contents of the container represent a hybrid load confaining 4 canisters of normal burnup, 2:1 at-reactor-consolidation, spent BWR fuel and 3 canisters of nomal burnup, 2:1 at-reactor-consolidation, spent PWR fuel. For all but one analysis, 1 assumed that both fuels were $10 \mathrm{yr}$ out of the reactor at the time of emplacement in the borehole. The remaining analysis assumes that the same number of spent fuel rods contain fuel $5 \mathrm{yr}$ out of the reactor at the time of emplacement. For the case with the $5 \mathrm{yr}$ old fuel the thermal load at emplacement is $56 \%$ greater than the $10 \mathrm{yr}$ old fuel reference case thermal load. All fuel canisters were double-parked (200\% of reactor density), except for the SCP layout case which contained rods consolidated to $173 \%$ of the reactor density.

At emplacement, the total power output of the container with double-packed, 10yr-old fuel is $4740 \mathrm{~W}$ (i.e., $360 \mathrm{~W}$ per BWR fuel canister and $1100 \mathrm{~W}$ per PWR fuel canister). That power per container with the given borehole spacing corresponds to a local power density (LPD) equal to $80 \mathrm{~kW} / a c r e$. The power output in the case wit? the SCP layout spacing is $86.5 \%$ of the reference 10 -yr-old fuel case. The power output at emplacement from the container with the 5-yr-otd fuel is $7392 \mathrm{~W}$ (i.e., $545 \mathrm{~W}$ per BWR fuel canister and $1737 \mathrm{~W}$ per PWR fuel canister), or a LPD equal to $125 \mathrm{~kW} / \mathrm{acre}$. The heat source in the 3-D model was detined as a volumetric heat generation rate with the assumption that the thermal contents are distributed over the borehole volume. For the 2-D analyses, the volumetric heat generation is based on a volume calculated from the cross section area of the individual fuel canisters and the length of the container. Table 1 documents the power output-time history of the individual fuel canisters and the respective power densities of the borehole and the fuel canisters. 


\section{Matenal Properties}

Water-impregnated volcanic tuff was chosen as representing the host rock of the repository. The reported thermal properties of the wetted tuff have changed substantially in the last few years and are still under investigation. Current isotropic material thermal properties for volcanic tuff are given in Table 2. The thermal properties of the tuff are assumed to change from the normal in-situ $80 \%$-saturated conditions to perfectly dehycarated conditions at $100^{\circ} \mathrm{C}$ without any heat of vaporization. When the host rock cools below $100^{\circ} \mathrm{C}$, thermal properties for $80 \%$ saturated tutf are immediately in effect even though it would take years for the tuff to rehydrate. Even though phase change takes place at this level at $97^{\circ} \mathrm{C}, 1$ used the existing $100^{\circ} \mathrm{C}$ data because this small variation ma',es no major difference in the predictioris of the borehole wall temperature or the peak cladding temperature. The effects of ignoring the heat of vaporization and the time required for rehydration of the dried tuff will be studied at another time. Predicted borehole wall and peak cladding temperatures are likely to decrease when the heat of phase change is included. As mentioned previously, the analyses neglect thermal performance effects of voids in the tuff that arise from drift tunnels, of ventilation in these dritt tunnels, and of migration of water/water vapor in the tuff induced by temperature gradients.

It has been proposed to pack the $0.05-m$-thick annulus between the container and ihe borehole wall with loosely packed or firmly packed bentonite at emplacement. The bentonite backfill is supposed to improve long-term container containment by absorting the local moisture and by suppressing diffusion of the radionuclides into the host rock after the container is breached. For the firmly packed bentonite backfill case, I assumed the properties of common bentonite deposits (25\% water-saturated at temperatures below $100^{\circ} \mathrm{C}$ ). The properties used for the firmly packed bentonite are documented in Table 2. When these analyses were started, the actual thermal properties of the loosely packed bentonite backfill were unknown. For the current analyses I was asked to assume that the volumetric heat capacity of the loosely packed backfill is equal to two-thirds of the firmly packed condition and the thermat conductivity is equal to one-fourth of the firmly packed condition. 20

Reference 5 looked at the effect of $0.15-\mathrm{m}$ thickness of bentonite packing inside the container on thermal performance after vertical emplacement. It uses a value for 
bentonite thermal conductivity about equal to the value I use for the ioosely packed backfill. Reference 7 looked at the performance effect of $0.15-\mathrm{m}$ thickness of bentonite container packing for horizontal emplacement. The thermal conductivity of the packing, from measurements, is about equal to my value for firmly packed bentonite.

The materiais for the structure of the container shell and fuel canister supports have not been chosen yet. For past thermal analyses we have assumed 304 stainless steel for these container components. In response to Project leadership suggestions for design analyses, ${ }^{21}$ we have considered 7030 cupronickel and incoloy 825 as well as the $\mathbf{3 0 4}$ stainless. The thermal properties for these three materials are also given in Table 2.

The actual heat transfer in the fuel canisters should be modeled in terms of individual fuel rods, the support basket, the gas fuel-canister fill, and the fuel-canister shell. The heat transfer parallel to the fuel rod's axis can be significantly difterent from the heat transfer normal to the rods axis. Additional variations result dependent on the orientation of the fuel carister relative to gravity. To simplify these initial analyses, 1 assumed an homogeneous, isotropic material in place of the individual components and used an equivalent, of "effective", thermal conductivity to predict the thermal response of these fuel canisters. For most analyses, the effective conductivity is based only on conduction through the fuel canister gas fill and thermal radiation exchange between these fuel rods. ${ }^{7}$

Temperature measurements from recent experiments on 2:1 consolidated fuel canisters have suggested that natural convection of the storage gas within a vertically stored fuel canister may raise the effective themal conductivity by as much as $35 \% .{ }^{18}$ An effective conductivity was determined from the reported steady-state temperature profiles by relating the test unit and its thermal response to a 2-D model with a closedform solution for heat transter in a rectangular canister with heat generation. The equivalent thermal properties for the double-packed spent fuel canisters used in these analyses are given near the end of Table 2. After the thermal properties of the proposed loosely packed backfill for the borehole annulus, the spent fuel canister equivalent conductivity has the least documentable support of the material thermal properties. 
I assumed dry air properties where conduction through the gas fill inside the container is modeled. The properties of diry air are given in Table 2. Most other potential fill gases, e.g., argon, have slightly poorer thermal conductivity. However, while helium has a much higher thermal conductivity, it would tend to leak out more rapidly. In the case of a leak, the gas fill might be displaced by air from the borehole.

\section{Initial and Boundary Conditions}

The initial temperature for the 3-D, transient, t.e. heat transfer analyses of the tuff is $25^{\circ} \mathrm{C}$. Although the temperature of the undisturbed tuff is really a function of depth (around $22^{\circ} \mathrm{C}$ at ground level to $36^{\circ} \mathrm{C}$ at $350 \mathrm{~m}$ ), assuming a constant $25^{\circ} \mathrm{C}$ does not atter the prediction of the heat flow significantly. ${ }^{7}$ For all but one case, a constant $25^{\circ} \mathrm{C}$ temperature boundary condition is applied on the faces of the elements modeling the earth's surface (see Figure 1a). All other surfaces are assumed to be adiabatic. I ran one 3-D case to show the effect of assuming an adiabatic boundary condition on the earth's surface compared to a $25^{\circ} \mathrm{C}$ condition.

The initial temperature for the 2-D transient f.e. heat transter analyses of the container is also $25^{\circ} \mathrm{C}$. In actuality, the fuel-filled container has some initial steadystate temperature distribution that results from its pre-emplacement storage/ transportation conditions. Because unis initial distribution affects only the thermal performance during the first few days after emplacement, an assumption of constant initial temperature made modeling sense.

For the cases with no backfill in the annulus, the heat-1ransfer model for the external surface of the container shell includes conduction through and convection in the water vapoi/air-filled annulus to the borehole wall and thermal radiation from the container shell to the borehole wall. The borehole wall temperature-time history is defined by the predicted temperatures from the 3-D analysis. The model assumes no condensation on the outside of the container. Table 3 contains the borehole wall temperature-time histories and the "convective" heat-transfer coefficient for this combined conduction/convection. This heat transfer coefficient was developed from correlations in Reference 19. I assumed natural convection and conduction in a vertical, constant-thickness annulus filled with saturated water vapor. The surface emissivities used for calculating thermal radiation heat transfer from the container and 
from the borehole wall are 0.8 and 1.0 , respectively. The 0.8 value for the container's outside surface includes the effect of dust and corrosion on surface emissivity. These are historical values that have been used in all previous LLNL analyses, and are kept because no better values are available.

Inside the container, the heat is transferred by conduction through the solid support stnucture, by thermal radiation between internal surfaces, by conduction across contact surfaces at supportfuel canister interfaces, by natural convection within the gas-iilied cavities, and by conduction through the gas fill. Natural convection in oddly shaped cavities with non-uniform heating is difficult to model, and it has been left to a later study to check its contribution to the tilermal performance. I expected, on the basis of previous work, that conduction and convection in the cavities would be a small contributor to the overall internal heat transfer. The reference case assumed the historically employed value of 0.8 for surface emissivity. While this value may be acceptable for the outside surface, recommended values of emissivity for the cleaner internal surfaces is somewhat lower. 22 Although I expected small increases in the predicted peak cladding temperature using the lower value of emissivity over those based on the 0.8 value, I ran an extra case to quantity the difference.

The contact thermal resistance between the fuel canisters and the support structure is assumed to be zero for all cases but one, where a more realistic value was used. Thermal radiation was expected to dominate the heat transfer; thus, the effect of modeling conduction through the gas was included in only three cases.

\section{Analysis Codes}

The f.e. mesh generator SLIC23 was used to prepare the 3-D f.e. geometry model. The conduction heat-transfer code TACO3D24 was used to calculate temperatures in the 3-D f.e. thermal model. The 2-D geometry mesh generator MAZE25 was used to prepare the 2-D f.e. geometry model. TACO2D26 was used to calculate temperatures in the 2-D f.e. thermal model. FACET ${ }^{27}$ was used for the 2-D f.e. thermal model to calculate the view factors for thermal radiation heat transfer inside the container. Six 3-D thermal analyses and twelve 2-D thermal analyses were completed and are documented in this report. Table 4 describes each of these eighteen analyses. 
NOTEJ:
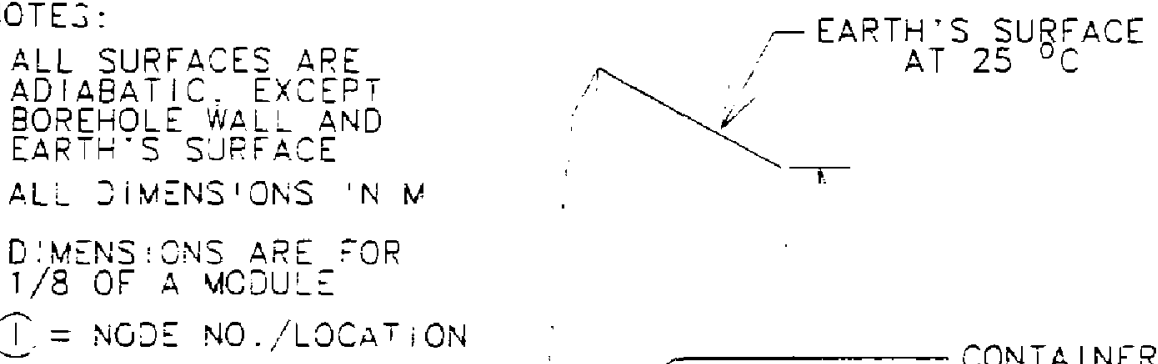

$\hat{I}=$ NODE NO./LOCATION CONTAINER CENTER - NE

ADIAGATIC PLANES

MIDWAY BETWEEN

BOREHCEES
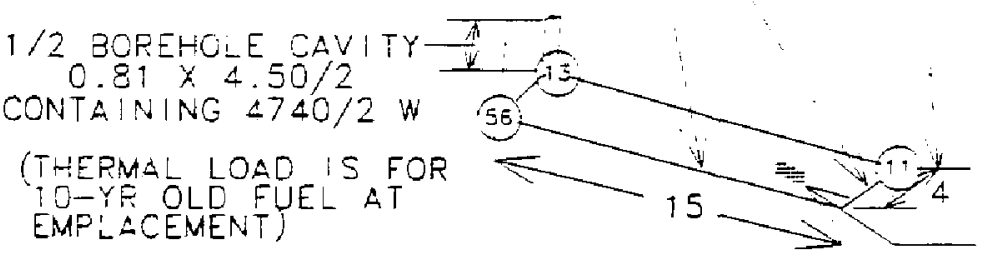

CAVITY MIDPLANE

Figure 1a. Geometry model used for 3-D analysis of the tuff has adiabatic planes at 4 and $15 \mathrm{~m}$ from the container axis. 


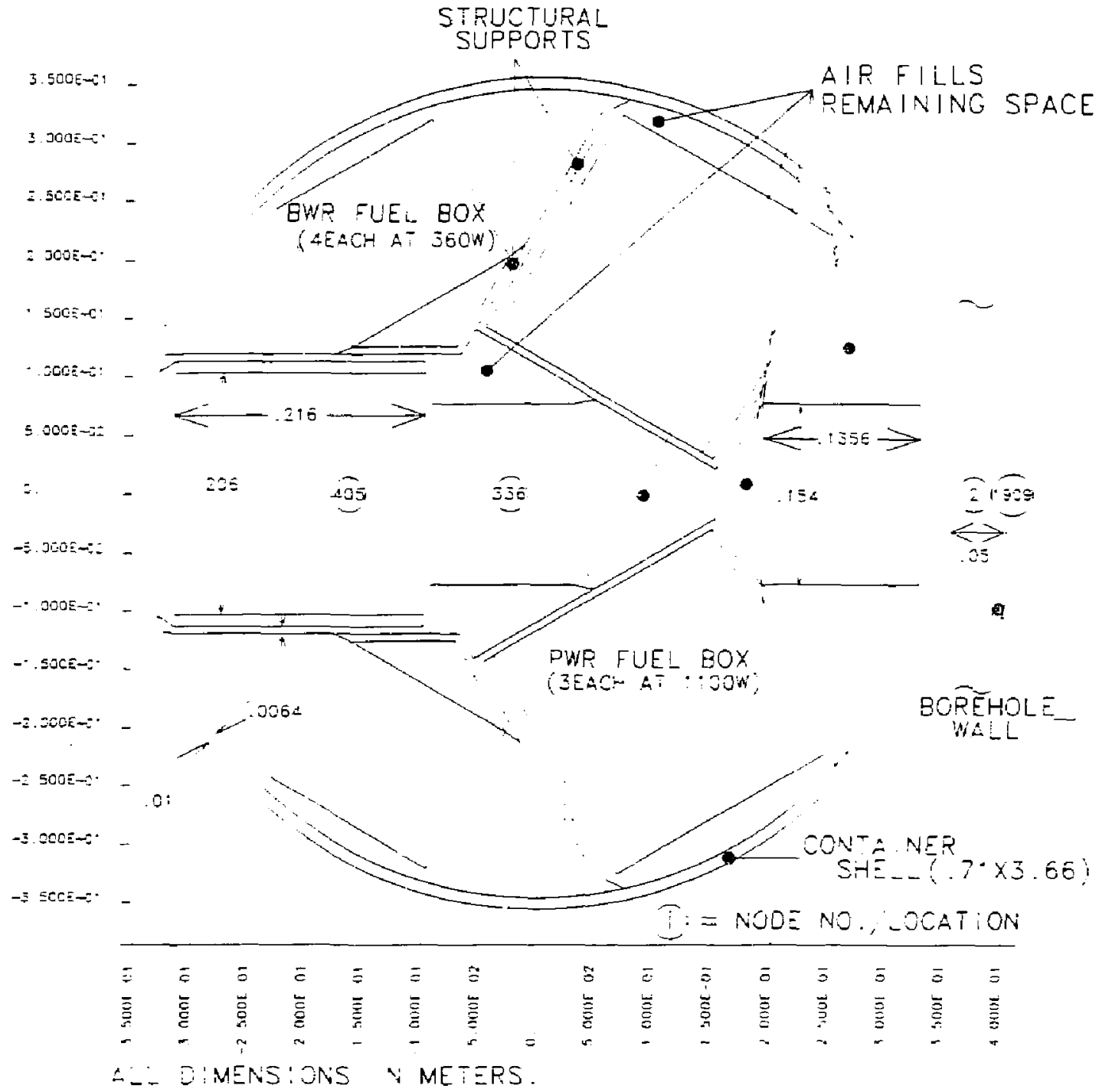

Figure 1b. Geometry model used for 2-D arialysis of container cross section assumes uniform power generation in the PWR and BWR fuel canisters over length of the container. 


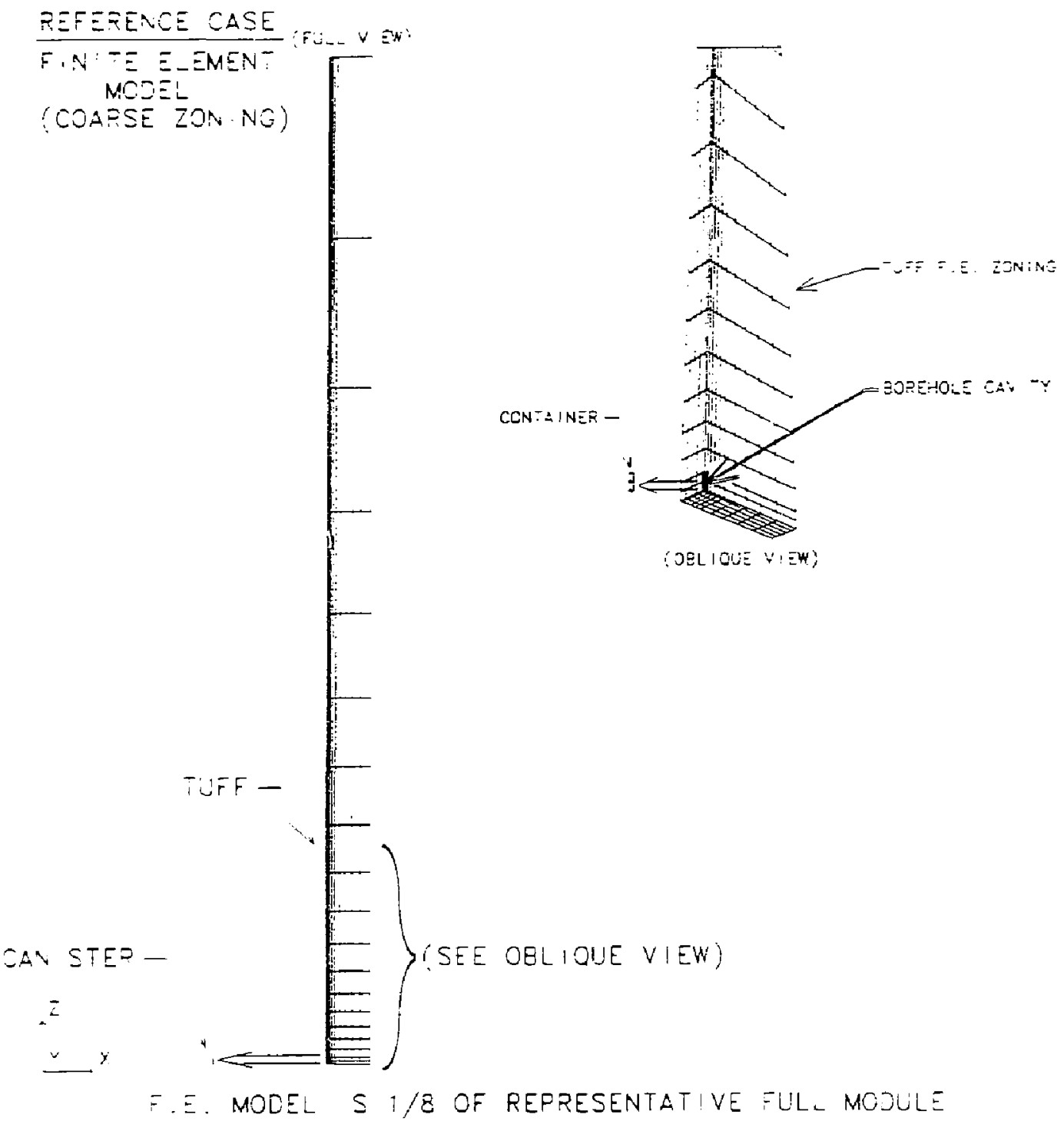

Figure 22. Finite element model used for 3-D analysis of tuff (coarsely zoned $m$ :stel used for the 3-D Reference Case. 


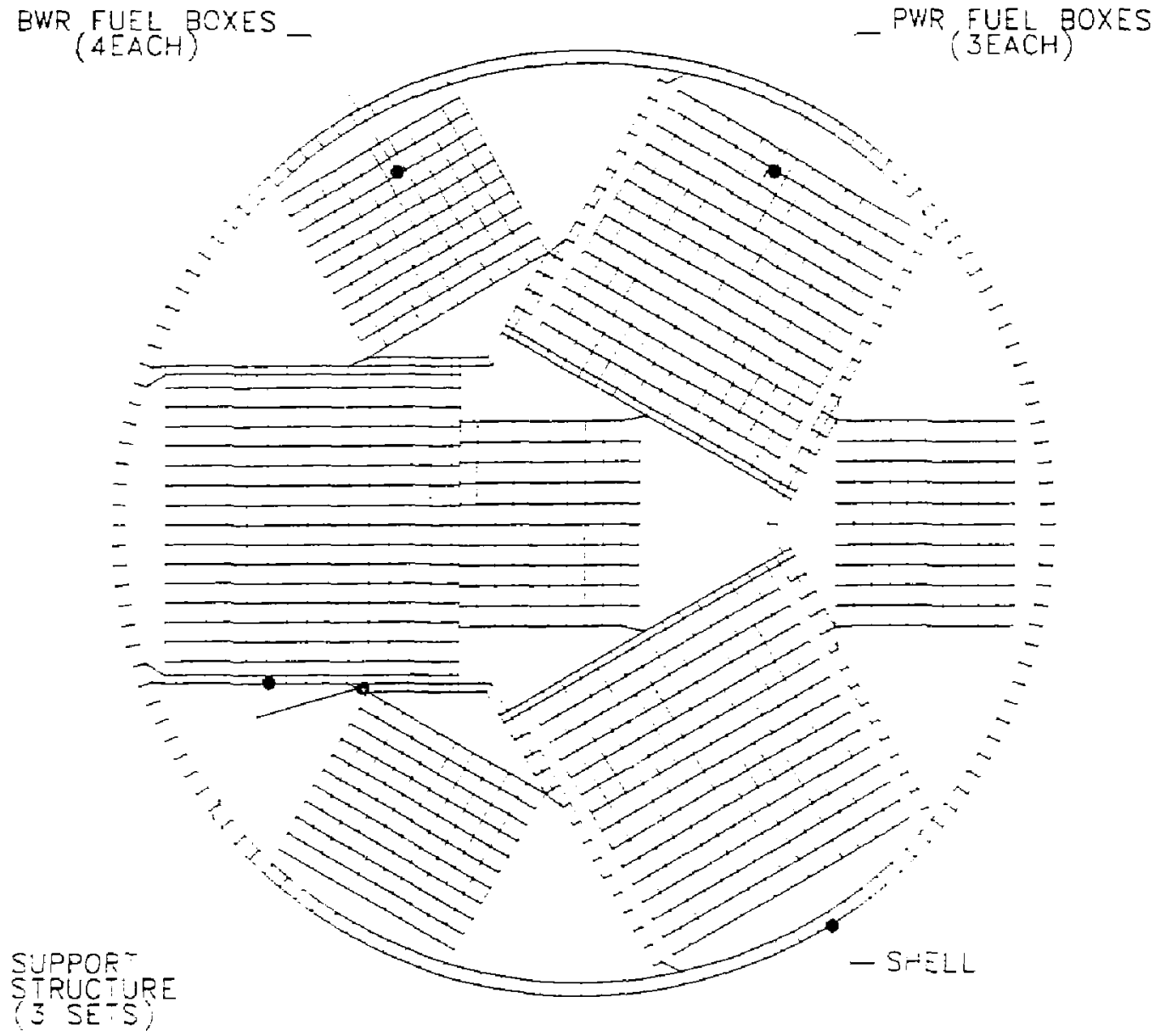

Z.E. MODEL ASSUMES CONSTANT FROPERT ES A_ONO LEVO-

Figure 2b. Finite element model used for 2-D analysis of container for ti.: cases without gas fill elements. 


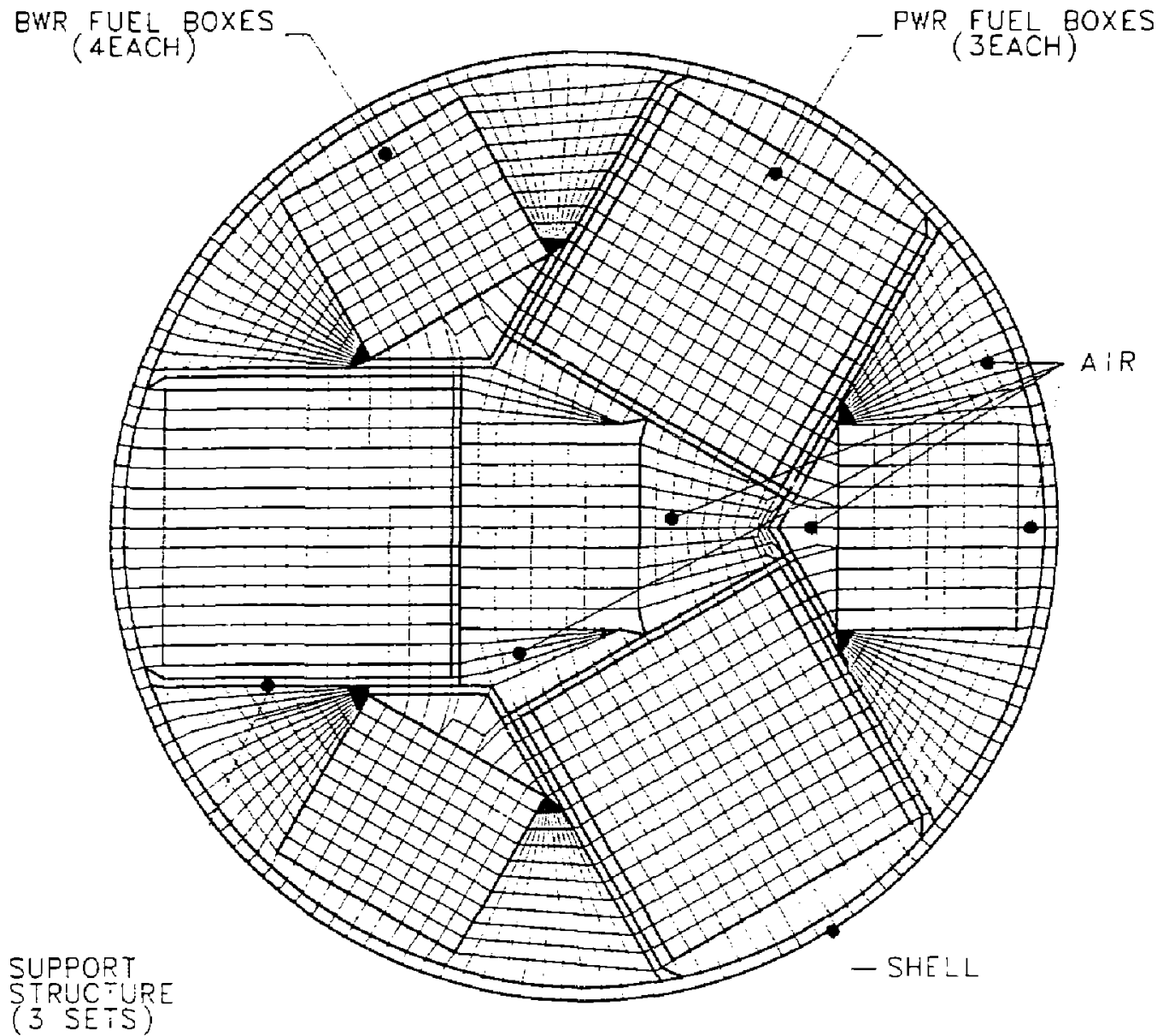

F.E. MODEL ASSUMES CONSTANT PROPERTIES ALONG LENGTH

Figure 2c. Finite element model used for 2-D analysis of container for the cases with gas fill elements. 


\section{3-D Analysis Results}

In review, the 3-D analyses model $350 \mathrm{~m}$ of tuff between the container midplane and the earth's surface for one quadrant of the $8 \times 30 \mathrm{~m}$ rectangular section associated with one container. It has adiabatic planes at 4 and $15 \mathrm{~m}$ from the container centerline (Figure 1a). Volumetric heat generation based on the container thermat load and the borehole volume provides the heat source. A $25^{\circ} \mathrm{C}$ boundary condition at the earn's surface provides the heat sink. The analyses will be used to define the borehole wall temperature-time history for use by the 2-D analyses as well as define the time the borehole wall temperature falls beiow $97^{\circ} \mathrm{C}$ or tutt temperatures exceeds $200^{\circ} \mathrm{C}$.

Figure 3 shows the predicted temperature-time histories for three nodes in the tuff for the 3-D Reference Case [Case 1a/3-D:coarse mesh case]. The three nodes afe located on the container midplane (Figure 1a). Node 13 is the location of the poak temperature on the borehole wall. Nodes 56 and 11 are on the adiabatic midplanes between adjacent boreholes and adjacem drifts, respectively. The node numbers identifying the curves are shown in parentheses. The minimum allowable borehole wall temperature, $97^{\circ} \mathrm{C}$, is shown for reference. An expanded view of the temperaturetime history for the first $50 \mathrm{yr}$ is shown as an inset in the upper right hand comer of the figure. Figure 4 shows, for the time of maximum borehole wall temperature, lines of consiant temperature (isotherms) on the borehole wall and on the surfaces of the tuff mocel raciating from the container axis. The borenole wall temperature-time history is documented in Table $3 \mathrm{~A}$.

For the 3-D coarse mesh case, the maximum temperature of the borehole wall, $204^{\circ} \mathrm{C}$, occurs at about 18 yr after emplacement. The temperature remains near the maximum value from 4 to $50 \mathrm{yr}$. The borehole wall stays above the $97^{\circ} \mathrm{C}$ minimum required temperature over the entire 1000-yr analysis period. Node 56 . which is $4 \mathrm{~m}$ from the borehole axis, reaches a maximum temperature of about $149^{\circ} \mathrm{C}$ at approximately $50 \mathrm{yr}$ after emplacement. Node 11 (15 $\mathrm{m}$ from the bo ehole axis) reaches a maximum temperature of $125^{\circ} \mathrm{C}$ at about $75 \mathrm{yr}$. The tuff temperature $1 \mathrm{~m}$ trom the borehole wall never exceeds $200^{\circ} \mathrm{C}$. Figure 4 shows that at the time of peak temperature the heat flow in the tuff becomes one-dimensional about 20 borehote diameters above the container midplane. 
Figure 5 compares the predicted temperature-time histories of the same three nodes for the case with the refined mesh and shorter calculative time step length [Case 1b/3-D:fine mesh case]. The histories for same three nodes from the reference case are included for comparison. The peak temperature of the borehole wall, $211^{\circ} \mathrm{C}$. is $7^{\circ} \mathrm{C}$ hotter than the reference case. Additional cases may be run during a later study to see if further refining the mesh increases the boreh sle wall temperature. The borehc ie temperature-time history for the 3-D fine mesh case is also documented in Table 3 A.

Figure 6 compares the isotherms near the borehole for these two cases. Note that the refined zoning/time step model results in larger temperature gradients near the borenole wall. Because this calculation was made near the end of the 2-D analysis series. I used the less conservative borehole wall temperature-time history from the 3D coarse mesh case for ati, but the best model thermal analysis case. That case uses the the hutter time history resulting from the 3-D fine mesh analysis.

Figure 7 shows predicted temperature-time histories from the 3-D analysis of tuff surrounding a container with an equal weight of 5-yr-old fuel [Case 6/3-D:5-year fuei case]. The zoning and time step length correspond to that of the 3-D reference case. The plotted time histories are for the same three nodes previously documented. Figure 8 shows the isotherms for this case at the time of maximum borehole walt temperature.

For the 5-year fuel case the maximum temperature of the borehole wall. $248^{\circ} \mathrm{C}$. occurs at about $1 \mathrm{yr}$ after emplacement. This temperature stays above $120^{\circ} \mathrm{C}$ over the entire $1000 \mathrm{yr}$. The tuff temperature $1 \mathrm{~m}$ into the tuff from the borehole wall reaches a maximum of about $185^{\circ} \mathrm{C}$ after some $30 \mathrm{yr}$. Note the spacing of the isotherms shown in Figure 8 indicates that for the time of maximum temperature the heated region is concentrated to the tuff within 1 to $2 \mathrm{~m}$ of the borehole. The borehole temperature-ime nistory for the 5-year fuel case is documented in Table $3 \mathrm{~A}$.

Figure 9 shows borehole wall predicted temperature-time histores for the model with the adiabatic ground suriace [Case 11/3-D:adiabatic surtace case] and the 3-D reference case. The effect of assuming an adiabatic upper surtace is only slightly 
noticeable near the end of the $1000-y r$ analysis period. Thus the heat flow $350 \mathrm{~m}$ from the container midplane is significant only after the first $1000 \mathrm{yr}$ of the storage.

Figure 10 compares the results from the Cidse 12/3-D:700 m depth case and the 3-D reference case $(350-\mathrm{m}$ model). Comparisons of the isotherms indicate that the heat flow is nearly symmetric about the centerplane of the container. The borehole wall only senses the non-symmetric boundary conditions after $700 \mathrm{yr}$ of storage.

Finally, Figure 11 shows the temperature-time history for Case 13a/3-D:SCP layoui case. The peak borehole wall temperature, $237^{\circ} \mathrm{C}$, is $30^{\circ} \mathrm{C}$ hotter than the corresponding case with $8 \times 30 \mathrm{~m}$ spacing. For a $20 \%$ increase in LPD over the reference case, the difference between the peak temperature and the upper surface temperature for this model increased by $16 \%$.

At the close of this section on 3-D analyses, let me restate the caveats for these resuits. These predictions assumed that the tutf section and container are modeled as if surrounded by an intinite array of similarly sized tuff sections housing containers with the same thermal loads emplaced nearly at the same time. Containers storing this high a thermal load would more probably be dispersed throughout the repository among containers with lower loads, thus leading to lower temperatures. For a given fuel age, variations in the LPD could be used to scale the expecied change in the peak-borehole-wall to upper-surface temperature difference. In all cases the only heat sink is the earth itself (with its upper surface set $10.250 \mathrm{C}$ where the model permits). Penturbations in the heat flow patterns due to drift tunnels or heat transfer to ventilation air circulating in these tunneis are not included in the model. Addition of these effects wouid lower the temperatures even more.

The effects of various loading distributions and the presence of ventilated dritt tunnels will be modeled in detail in other analytic tasks this year. Some eartier studies using linear superposition theory for multiple sources (Citations 7.8 of Appendix A) indicated that the maximum borehole wall temperature and its corresponding peak cladding temperature may be substantially lower than the infinite array value. These 
studies concluded that the effect of including the drift tunnel in the model would decrease these temperatures by 5 to $10^{\circ} \mathrm{C}$. Including the drift tunnel and its associated humidity and heat removal by ventilation will also allow the analyst to determine if the barrier design could satisfy another project thermal limit. This limit requires that the temperature of the drift floor for the first $30 \mathrm{yr}$ must remain cooler than the $50^{\circ} \mathrm{C}$ limit to provide for manned operations in the drift. Because the borehole wall temperature for arrays of highly loaded containers nears $200^{\circ} \mathrm{C}$, these calculations become an absolute necessity. 


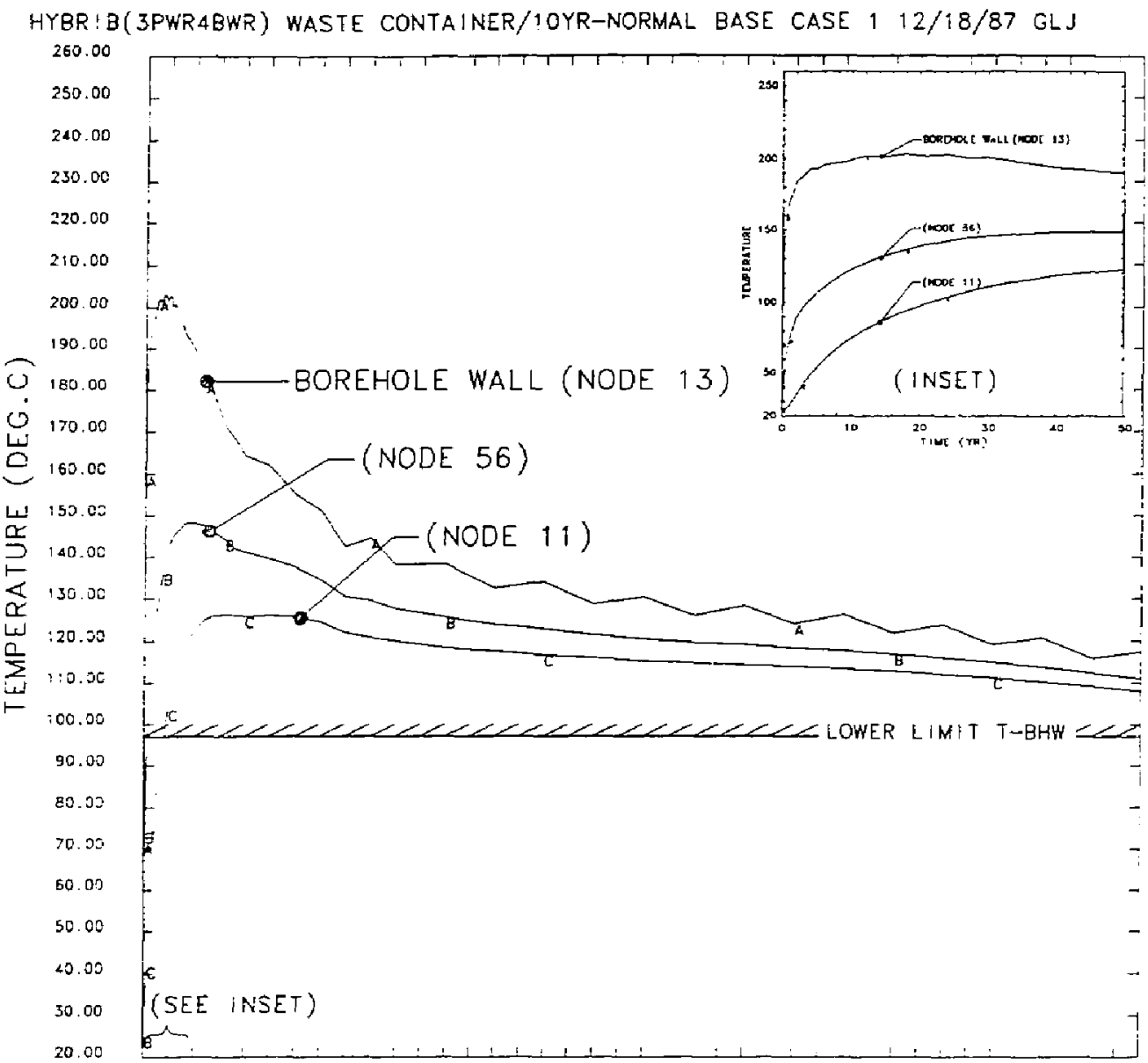

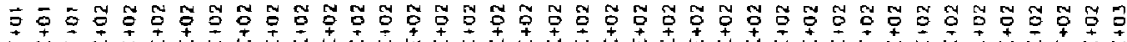

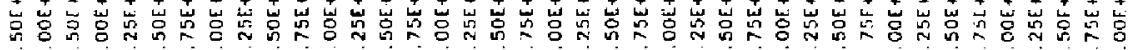
TIME (YEARS)

Figure 3. The temperature of the borehole wall for the reference case exceeds $204^{\circ} \mathrm{C}$ at $18 \mathrm{yr}$ after emplacement and remains above $97^{\circ} \mathrm{C}$ for the entire $1000 \mathrm{yr}$. 
HYBRIE(3PWR4BWR) WASTE CONTAINER/1OYR-NORMAL BASE CASE $112 / 18 / 87$ GLJ

TIME $=1.80000 E+01$ YEARS

$M I N=2.500 E \div 01$ AT NODE 1320 MAX $=2.040 E+02$ AT NODE

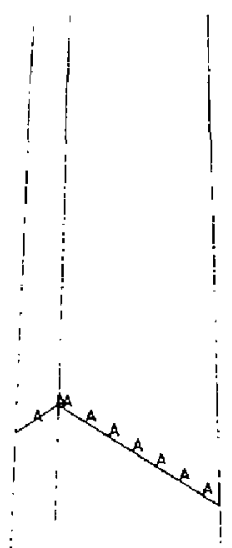

CONTOURS OF TEMPERATURE

(DEG.C)

$A=5.00 E+01$

$B=7.50 E+01$

$C=1.00 E+02$

$D=1.25 E+0.2$

$E=1.50 \mathrm{E}+02$

$\mathrm{F}=1.75 \mathrm{E}+02$

$G=2.00 \mathrm{E}+02$

$\mathrm{H}=2.25 \mathrm{E}+02$

$1=2.50 E+02$

BOREHOLE REGION ISOTHERMS

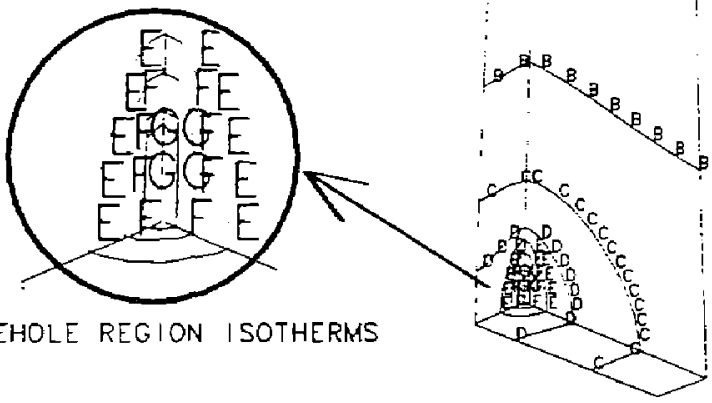

$\int_{x}^{2} x$

Figure 4. The heat flow in the tuff is one-dimensional above about 20 borehole diameters from the container midplane. 
HYBR IB(3PWR 4BWR) WASTE CONTAINER/1OYR-NORMAL BASE CASE 1 12/18/87 GLJ

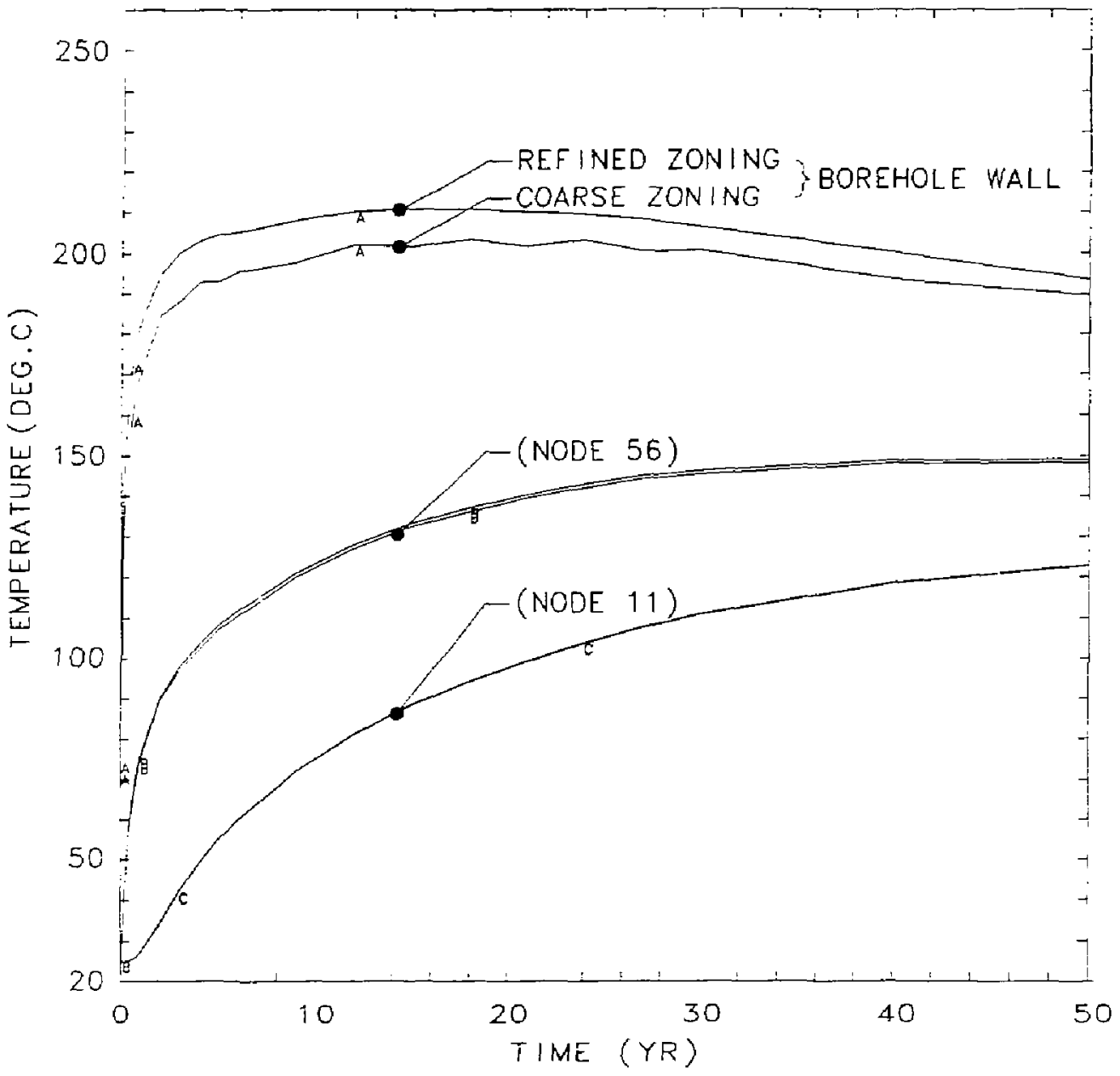

Figure 5. The predicted peak temperature of the borehole wall is $7{ }^{\circ} \mathrm{C}$ hotter for the f.e. model with refined zoning and time step length than the 3-D reference case with its coarser zoning and time step. 
HYERIB(3PWR4BWR) WASTE CONTAINER/1OYR-NORMAL BASE CASE 1 12/18/87 GLJ

\section{$T / M E=1.80000 E+01$ YEARS}

$M I N=2.5 C O E+01$ AT NODE 1320 $M A X=2 . G 4 O E+O 2$ AT NODE

CONTOURS OF TEMPERATURE

(DEG,C)

$A=5.0 D E+01$

$B=7.50 E+01$

$C=1.00 E+02$

$\mathrm{Q}=1.25 \mathrm{E}+02$

$E=1.50 E+02$

$F=1.75 E+02$

$\mathrm{G}=2.00 \mathrm{E}+02$

$\mathrm{H}=2.25 \mathrm{E}+02$

$\mathrm{I}=2.50 \mathrm{E}+02$
$\mathrm{TIME}=1.80000 E+01$ YEARS

$M I N=2.500 E+G 1$ AT NODE 2640 MAX $=2.107 E+C 2$ AT NODE 13

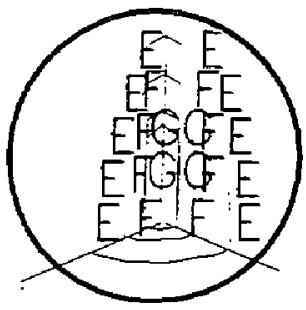

BOREHOLE REGION ISOTHERMS COARSE ZONING

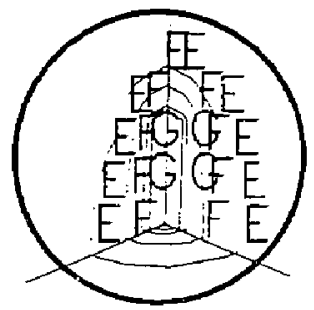

BOREHOLE REGION ISOTHERMS REF INED ZONING

Figure 6. The near-field temperature gradient in the tutf increases somewhat in the case with the refined zoning and time step length. 


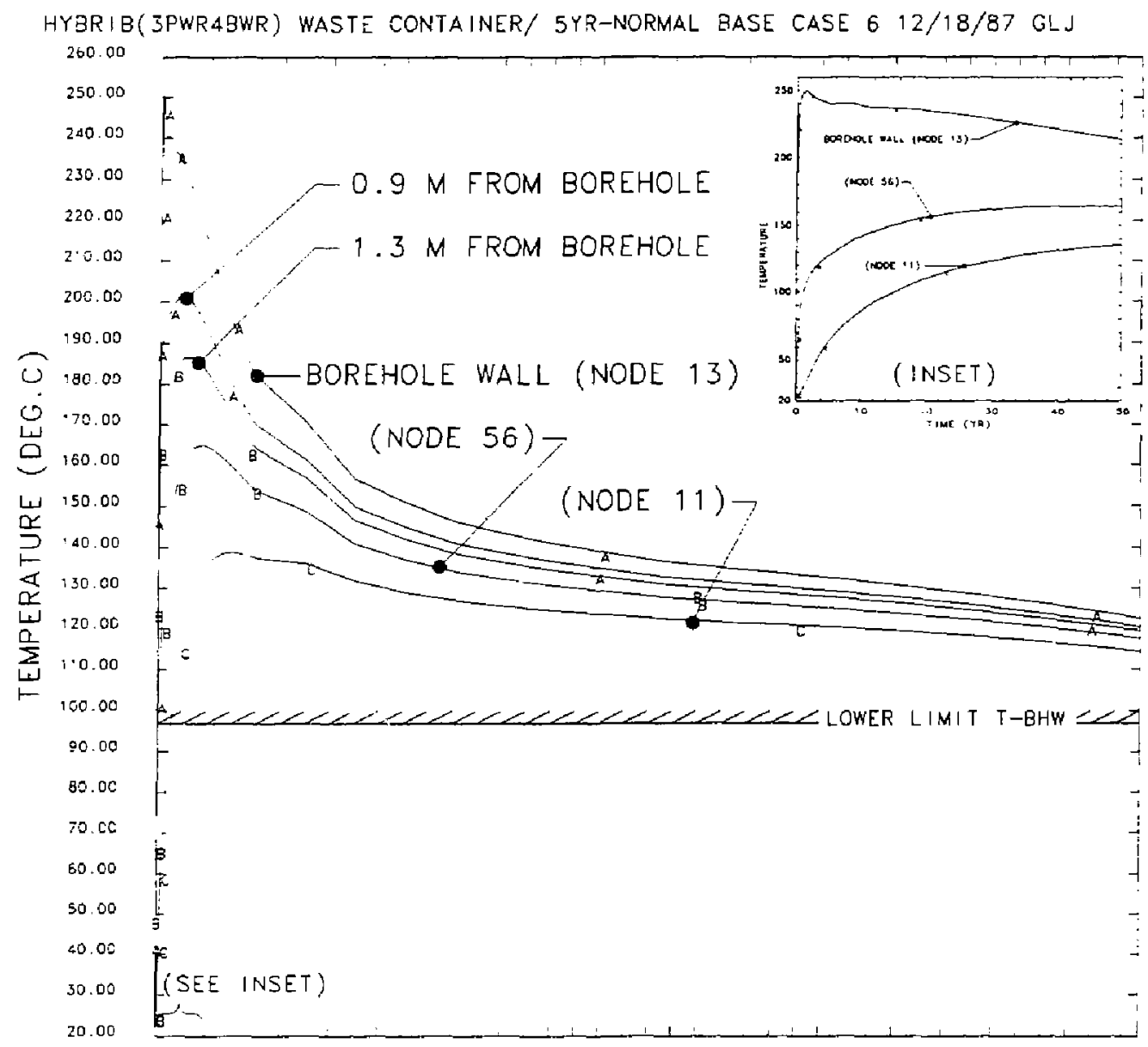

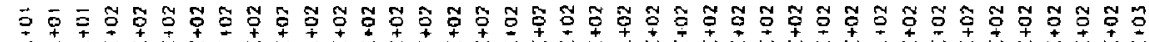

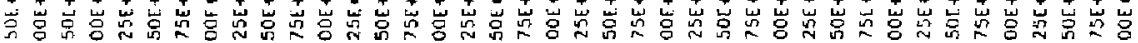

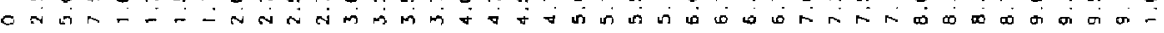
TIME (YEARS)

Figure 7. The maximum temperature of the borehole wall for the f.e. model with 5-year-old fuel nears $250^{\circ} \mathrm{C}$ at about $1 \mathrm{yr}$ after emplacement. The tutf at $1 \mathrm{~m}$ never exceeds $200^{\circ} \mathrm{C}$. 
HYBR IE(JPWR AEWF! WASTE CONTAINER/ SYR-NORMAL GASE CASE $612,9 / 8 ?$ GLJ

T:ME = I. OSOOOE+0OYEARS

$M I N=2.500 E-C: \quad A T$ NODE 2256

MAX $=2.485 E+C$ ? $A T$ MODE 13

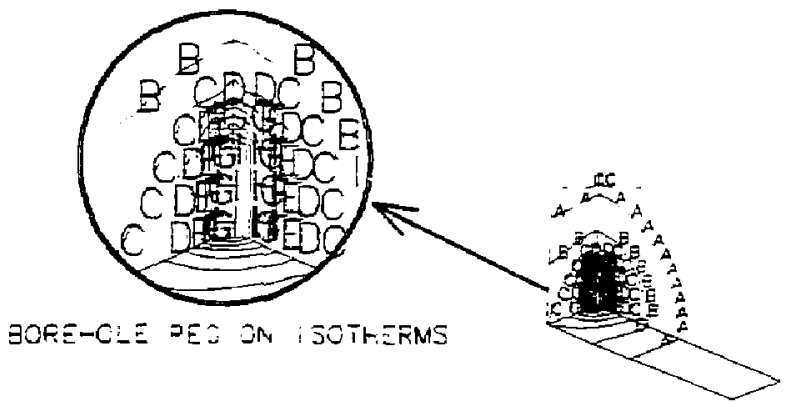

CONOUPS OF TEMPERATURE

IJEG.

$A= \pm .00 E-01$

$3=7.50 E+0^{\prime}$

$C=1.00 E+02$

$\mathrm{D}=: .25 \mathrm{E}+02$

$E=. .50 E+02$

$\mathrm{F}=+.75 \mathrm{E}+02$

$G=2.00 E+02$

$H=2.25 E-02$

$i=2.50 E+02$

Figure 8. The near-field temperature gradient in the tusi at the time of peak borehole wall temperature is very large. The tuff at 1 m never exceeds $200^{\circ} \mathrm{C}$. 


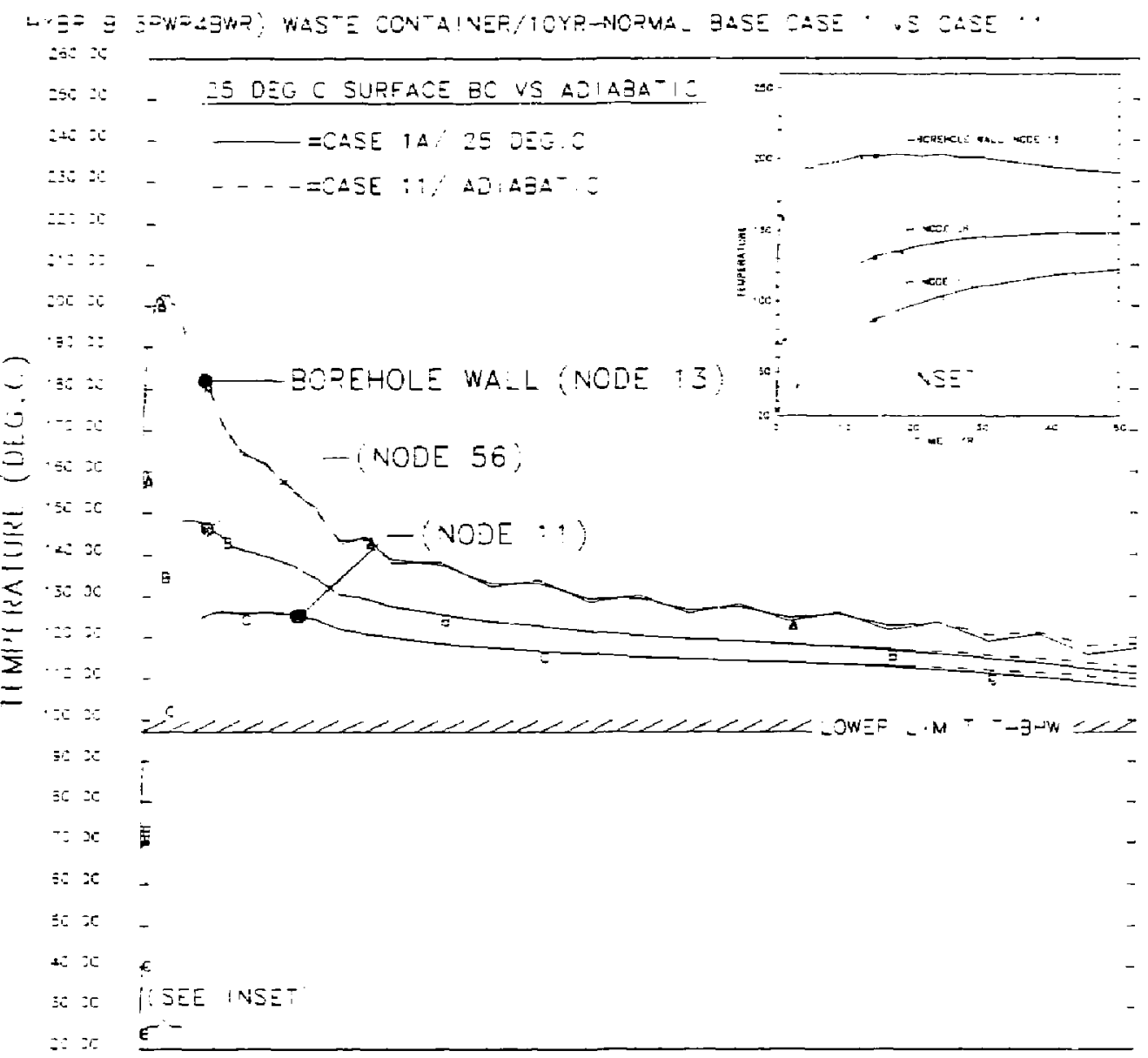

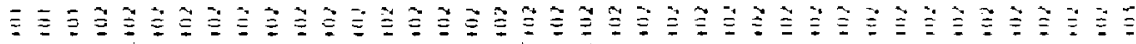

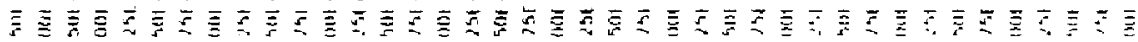
TIME (YEAFS

Figure 9. The predicted temperature of the tuff depends on the boundary condition at the earth's surface only at times nearing $1000 \mathrm{yr}$. 


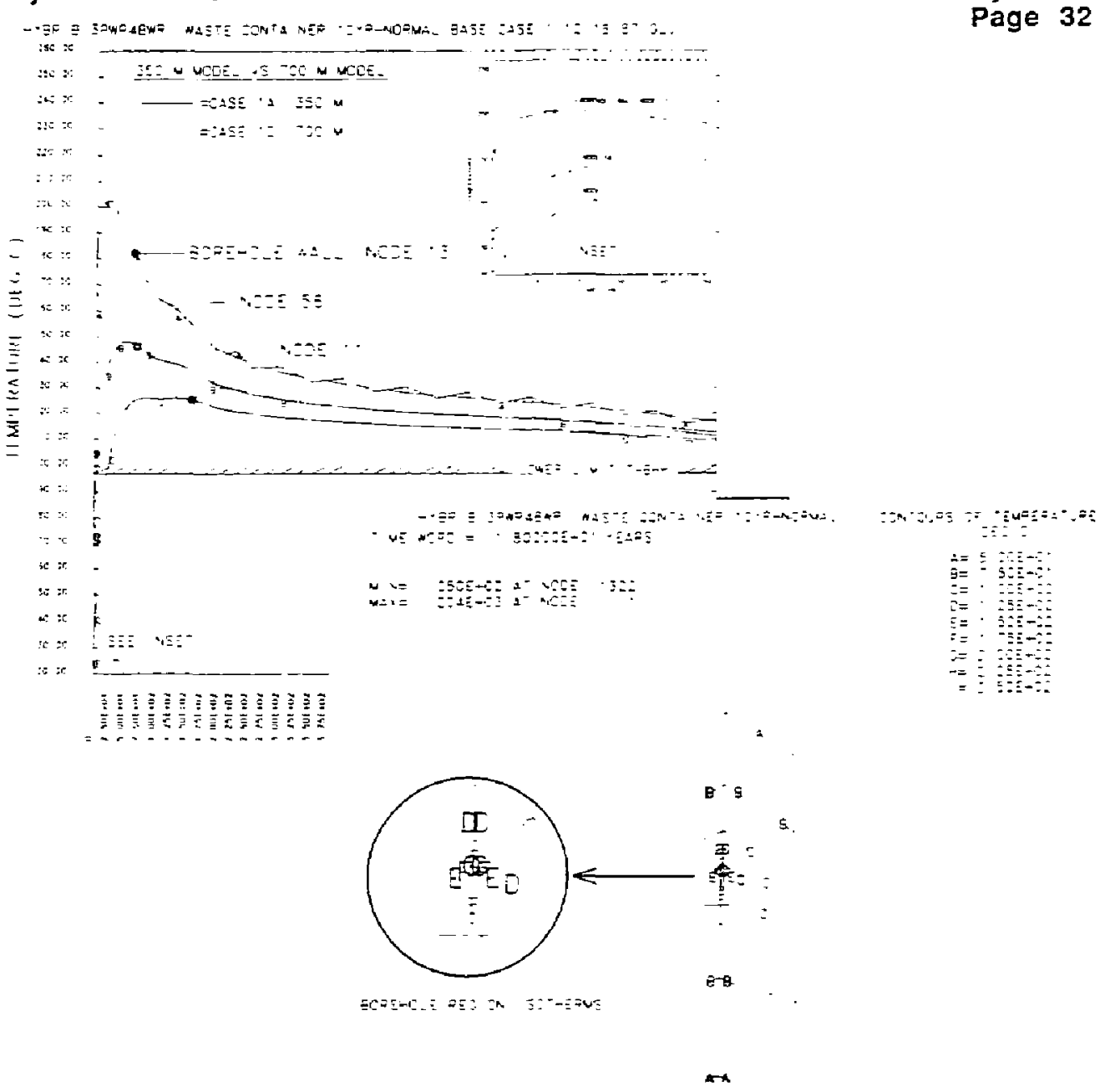

Figure 10 . Differences in thermal performance between the $350 \mathrm{~m}$ case and the $700 \mathrm{~m}$ case only become noticeable after $800 \mathrm{yr}$. Isotherms for the $700 \mathrm{~m}$ case show that the heat flow is nearly symmetric about the container's centerplane. 


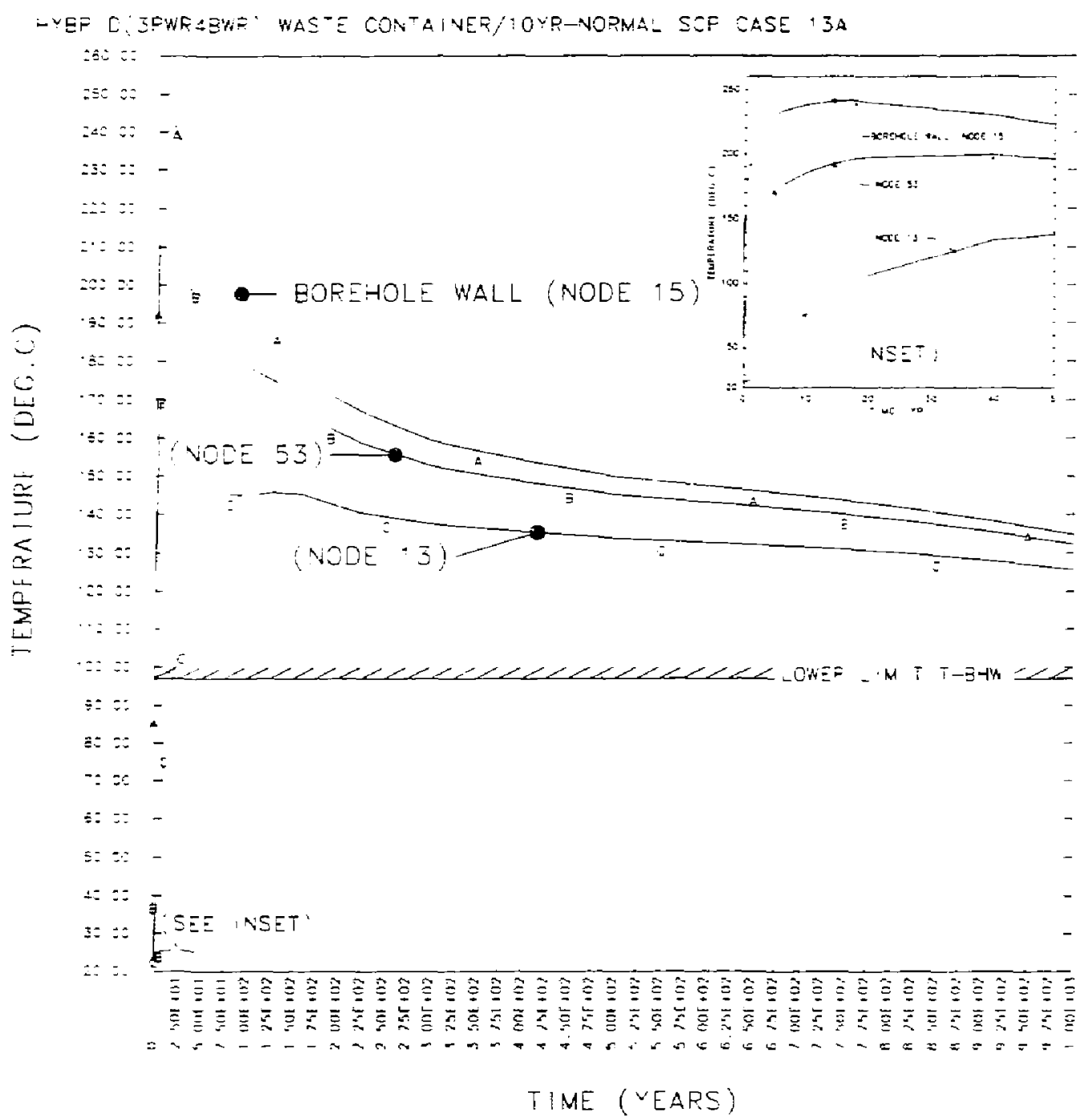

Figure 11. Storing 10-yr-old fuel at a 1.73:1 consolidation with the $15 \times 126$ it spacings defined in the SCP results in a peak borehole wall temperature to $237^{\circ} \mathrm{C}$. 


\section{2-D Analysis Results}

In review, the 2-D analyses model a mean cross section of the container midplane (Figure 1b). The heat source from the container thermal load is modeled as volumetric heat generation referenced to the PWR and BWR fuel-can volumes. The appropriate borehole wall temperature-time history from tiie 3-D analyses provides the heat sink. The analyses will determine if the fuel cladding temperature exceeds $350^{\circ} \mathrm{C}$ and the prediction's sensitivity to various model parameters

Figure 12 shows the predicted temperature-time histones of four nodes from the 2-D analysis of a container whose shell and internal support structure are made of 304 stainiess steel [Case 1:304SS]. The node numbers identifying the curves are shown in parentheses. Node 2 is on the external surface of the container, and Node 1909 is on the boretiole wall (see Figure 1b). Node 403 is near the center of the leftmost PWR ivel canister, and Node 336 is near the center of the central BWR fuel canister. These nocies were chosen as locations near the peak fuel temperatures after a review of the isotherm plots for times of peak cladding temperature (see Figure 13). These same nodes will be used consistently for documenting the peak temperatures, although the iocstion of the actual peak shitts stightl, with the thermal model. Because the local iemperature profile near the center of the fuel canister is rearly flat. the variation in temperature between the plotted node and the actual peak temperature tocation should be less than $2^{\circ} \mathrm{C}$. The temperatures at these nodes are assumed to represent an upper bound on the fuel cladding temperature. The maximum allowable ciadding temperature is shown for reference in the time history plots where needed. An expanded view of the temperature-time history for ine first $50 \mathrm{yr}$ is shown as an inset in the upper right-hand corner.

The maximum temperature of the PWR fuel (i.e., cladding) for the $304 S S$ case is $329^{\circ} \mathrm{C}$. It occurs at about $3 \mathrm{yr}$ atter emplacement. The maximum temperature of the $B W R$ cladding for the $304 S S$ case is $313^{\circ} \mathrm{C}$, which also occurs about 3 yr after emplacement. These peak cladding temperatures are substantlally warmer than those of many of the previous analyses. In fact they approach the $350^{\circ} \mathrm{C}$ riaximum altowed value. The ciadding temperature remains near the peak value ior only aoou: $5 \mathrm{yr}$. 
Outside surface temperatures of the container shell are used to evaluate the corrosion/oxidation rates. For this container the temperature around the outside diameter of the container shell may vary by as much as $10^{\circ} \mathrm{C}$ (see figure 18 ). The warmest portion of the external surface of the container comes within 2 to $5^{\circ} \mathrm{C}$ of the uniform borehole wall temperature over the 1000-yr analysis period. The coolest portion stays about 5 to $15^{\circ} \mathrm{C}$ warmer than the borehole wail. A 3-D analysis of the container and tuff would show variations in the borehole wall temperature giving a more uniform variation in the temperature difference between the container surface and the borehole wall.

A heat balance on the predicted heat transfer from the container shell to the borehole wall indicates that only $20 \%$ of the heat is iransferred by conduction/convection through the air/water vapor layer, and the remaining portion is transferred by thermal radiation. This $1: 4$ ratio is characteristic of past analyses.

Figure 14 shows the predicted temperature-time histories of the same four key nodes for the analysis modeling the design with 7030 cupronicke! container/support materials [Case 2:7030 case]. Isotherms at the time of peak temperatures are shown in Figure 15.

The maximum temperature of the PWR ciadding for the 7030 case is $325^{\circ} \mathrm{C}$ and the maximum temperature of the BWR cladding is $304^{\circ} \mathrm{C}$. Note that because of the improved conduction through the support structure the central BWR canister (with its smaller heat source) stays much cooler than the hottest PWR carister. They reach a common peak temperature after $100 \mathrm{yr}$.

Figure 16 snows the predicted temperature-time histories of the Incoloy 825 contaner/support model [Case 3:IN825 case]. This is my 2-D Reference Case. Isotherms at the time of peak temperatures are shown in Figure 17. Figure 18 shows a charactenstic temperature profile around half of the container perimeter at the time peak cladding temperature occurs.

The maximum temperature of the PWR cladding for the 1 N825 case is $336^{\circ} \mathrm{C}$. It also occurs at about $3.5 \mathrm{yr}$ after emplacement. The corresponding maximum temperature of the BWA cladding is $323^{\circ} \mathrm{C}$. I have used this case as the reference for 
the remaining studies because it gives the highest cladding temperature of the three cases testing the effect of material choice. Figure 19 contains a synopsis of these three cases in terms of the peak ciadding temperatures of the PWR fuel. Because the effect of structural material choice is small $\left(<12^{\circ} \mathrm{C}\right.$ between the poorest heat conductor, (N825, and the best conductor, 7030), it suggests that most of the decay heat is transierred to the shell by thermal radiation.

Figure 20 shows results of the 2-D analysis of the Incoloy 825 container with loosely packed bentonite backfill surrounding the container [Case 4:loose backfill]. Nodes 2. 403, and 336 are the same as before, but Node 2195 now defines the borehole wall temperature (i.e., edge of backiill). Figure 21 shows the isotherms in the coniainer and tuff backfill.

The maximum temperature of the PWR cladding for the loose backfill case is $391{ }^{\circ} \mathrm{C}$, while the maximum temperature of the BWR cladding is $383^{\circ} \mathrm{C}$. The loose bentonite backfill is a significantly poorer conductor for the thermal laad to the borenole wall than the combined conduction, convection, and thermal radiation dicross the humid air layer when no backfill is installed. Analyses documented in References 5 and 7 on the effect of backfill instalied within the container resulted in similar increases in peak cladding temperature.

Figure 22 shows the predicted temperature-time histories of the 2-D analysis of the Incoloy 825 container with firmly packed bentonite backfill surrounding the container [Case 14:firm backfill]. Figure 23 shows the isotherms in the container and backill at the time of peak cladding temperature.

The maximum temperature of the PWR cladding for the firm backfill case is $341^{\circ} \mathrm{C}$ while the maximum temperature of the BWR cladding is $329^{\circ} \mathrm{C}$. While the firmly packed bentonite's thermal conductivity is only three to four times higher than the ioosely packed bentonite, it lowers the peak cladding temperature back to nearly the value predicted for the case witn the unfilled annulus.

Figure 24 shows a time history comparison of the IN825 case (no backtill), the loose backtill case, and the firm oackill case in terms of the peak cladining temperatures of the PWR fuel. These results are very similar to those of previously 
reported analyses. It is not possibie to conclude that the thermal performance of firmly packed bentonite backfill is acceptable because these results are so sensitive to the assumed thermal conductivities of the backfill, which are not necessarily represeniative of conditions in the repository.

Figure 25 compares the peak cladding temperatures of the PWA fuel of the IN825 case (no contact thermal resistance between the support structure) with the case using calculated contact thermal resistances based on a 100-psi contact pressure and an air interface heat transfer medium (Case 5:contact resistance case). The resultant order-of-magnitude change in contact resistance does not have an obsarvable effect in the temperature history of the PWR or BWR fuel canisters. Again, this is due to the dominance of the thermal radiation heat transfer mode inside the coniainer.

Figure 26 contains temperature-time nistories from tne 2-D analysis of the Incoloy 825 container loaded with an equal number of 5 -yr-old fuel rods replacing the 10-yr-old tuel [Case 6:5-year fuel case]. Isotherms at the time of peak temperatures are shown in Figure 27.

The maximum temperature of the PWR cladding for the 5-year fuel case is $411^{\circ} \mathrm{C}$. It occurs at about 8 months after emplacement. The maximum temperature of the BWR cladding is $399^{\circ} \mathrm{C}$. I included this case in the hybrid thermal performance study to give a feeling for the effect of storing 5-yr-old fuel in a contiguous repository array. High-bumup 10-yr-old fuel would give a similar response.

Figure 28 and Figure 29 document the thermal response of the Incoloy 825 container if a surface emissivity of 0.5 is assumed on inside surfaces [Case 7 :emissivity case] rather than the 0.8 value that was used in previous analyses. The thermal resistance to radiative heat iransier is inversely proportional to the suriace emissivity. Thus 1 expected an increase in peak cladding temperature because the heat transter inside the container is dominated by thermal radiation.

The maximum temperature of the PWR cladding for the altered emissivity case is $346^{\circ} \mathrm{C}$, and the maximum temperature of the BWR cladding is $339^{\circ} \mathrm{C}$. As with the highly conductive 7030 container, the smaller difference between the BWR and PWR 
peak temperatures primarily results from the increased dependence of heat transfer through the structural supports. Figure 30 compares the PWR and BWR thermai responses for the two values of surface emissivity. The lower (and more realistic) emissivity raises the peak temperature by about $10^{\circ} \mathrm{C}$. This puts it just about on the maximum allowed cladding temperature.

The temperature-time histories shown in Figure 31 and the isotherms in Figure 32 model the thermal response of an Incoioy 825 container with thermal conductivities for the spent fuel canisters derived from measured temperature profiles [Case 8.tuel conductivity case].

The maximum temperatures of the PWR and BWR cladding for the fuel concuctivity case are 322 and $315^{\circ} \mathrm{C}$, respectively. The comparison with the reference case in Figure 33 shows the higher assumed thermal conductivity of the fuel rod bundles lowers the peak temperature by 8 to $15^{\circ} \mathrm{C}$. This change substantially increases the thermal performance margin because the peak cladding temperature in the reference case is so near the maximum allowable.

The 2-D analysis of the Incoloy 825 container including the effect of heat concuction through the gas fill [Case 9:gas conduction] gives predicted temperaturetime histories shown in Figure 34 and isotherms like those shown in Figure 35.

The maximum temperature of the PWR cladding for the gas conduction case is $335^{\circ} \mathrm{C}$, and the maximum temperature of the BWR cladding is $322^{\circ} \mathrm{C}$. The net $1{ }^{\circ} \mathrm{C}$ change in peak temperature between this case and the reference case implies that total heat conduction through the gas fill is minimal, and thermal radiation between inside surtaces remains the dominant heat transfer mode. Comparison of the isotherms in the structure and fuel for the gas conduction case with those for the reference case show no obvious differences. Including natural convection in the cavity heat transfer model would decrease the peak temperature further, but probably not enough to overwhelm the dominance of the thermal radiation.

Concluding these parametric studies, Figures 36 and 37 document the predicted temperature-time histories from a "best model" 2-D thermal analysis of an Incoloy 825 container incorporating information gained from the earlier analyses of 
this study. It uses the borehole wall time history of the fine-zoned tuff for the 10-yr-old fuel load (from the 3-D fine mesh case), a more accurate surface thermat emissivity for the internal surfaces equal to 0.5 (from Case 7 ), a tuel canister thermal conductivity derived from the Battelle-measured data (from Case B), and internal heat conduction through the gas fill (from Case 9).

The maximum temperature of the PWR cladding for best model case is $336^{\circ} \mathrm{C}$ and the maximum temperature of the BWR cladding is $334^{\circ} \mathrm{C}$. The near equality of these peak temperatures results from the combination of assumed higher thermal conductivity in the fuel pack, inclusion of heat transfer through the gas fill, and reduced heat transter by thermal radiation.

To put these results in the context of the current repository borehole layout. Figures 38 and 39 show a prediction of the thermal performance of a container filled with 4100 W PWR and BWA fuel distributed among the same seven canisters [Case 13a:SCP layout]. The container is surrounded with similarly loaded containers on $15 \times 126 \mathrm{ft}$ borehole spacings $(4.6 \times 38.4 \mathrm{~m})$. Except for the thermal load and the borehole spacing, the model uses the same assumptions as the best model discussed previously. The $4100 \mathrm{~W}$ power output was established by trial and error to give similar response to the "best model" case.

The maximum temperatures of the PWR and BWR cladding for SCP layout case are 335 and $334^{\circ} \mathrm{C}$, respectively. Thus, using the SCP-defined spacing would be acceptable with only a $15 \%$ decrease in the thermal load.

Because the 2-D results are driven by the borehole wall temperature-fime history generated in the 3-D analyses, the caveats to the 3-D results are pertinent here also. Some additional cautions pertain just to the 2-D analyses. The models used for these temperature predictions assume that the mean section of the container analyzed is representative of the response of the whole container. Axial variations in geometry. material properties, and thermal loac may cause temperatures to vary by 11 to $33^{\circ} \mathrm{C}$ from the mean section values (Reference 1 in Appendix B). Values assumed for the material properties, like the fuel canisters' thermal conductivity and structure's surface emissivity, may be off by 30 to $50 \%$, thus, significantly altering the container's predicted margin below the $350^{\circ} \mathrm{C}$ cladding temperature limit. Finally, the large 
Cavities between fuel canisters probably experience significant heat transfer from natural convection. This would peduce the fuel temperatures. 
HYBRIE(3PWR4BWR) SS304 CONTAINER/1OYR-NORMAL BASE CASE $112 / 18 / 87 \mathrm{GLJ}$

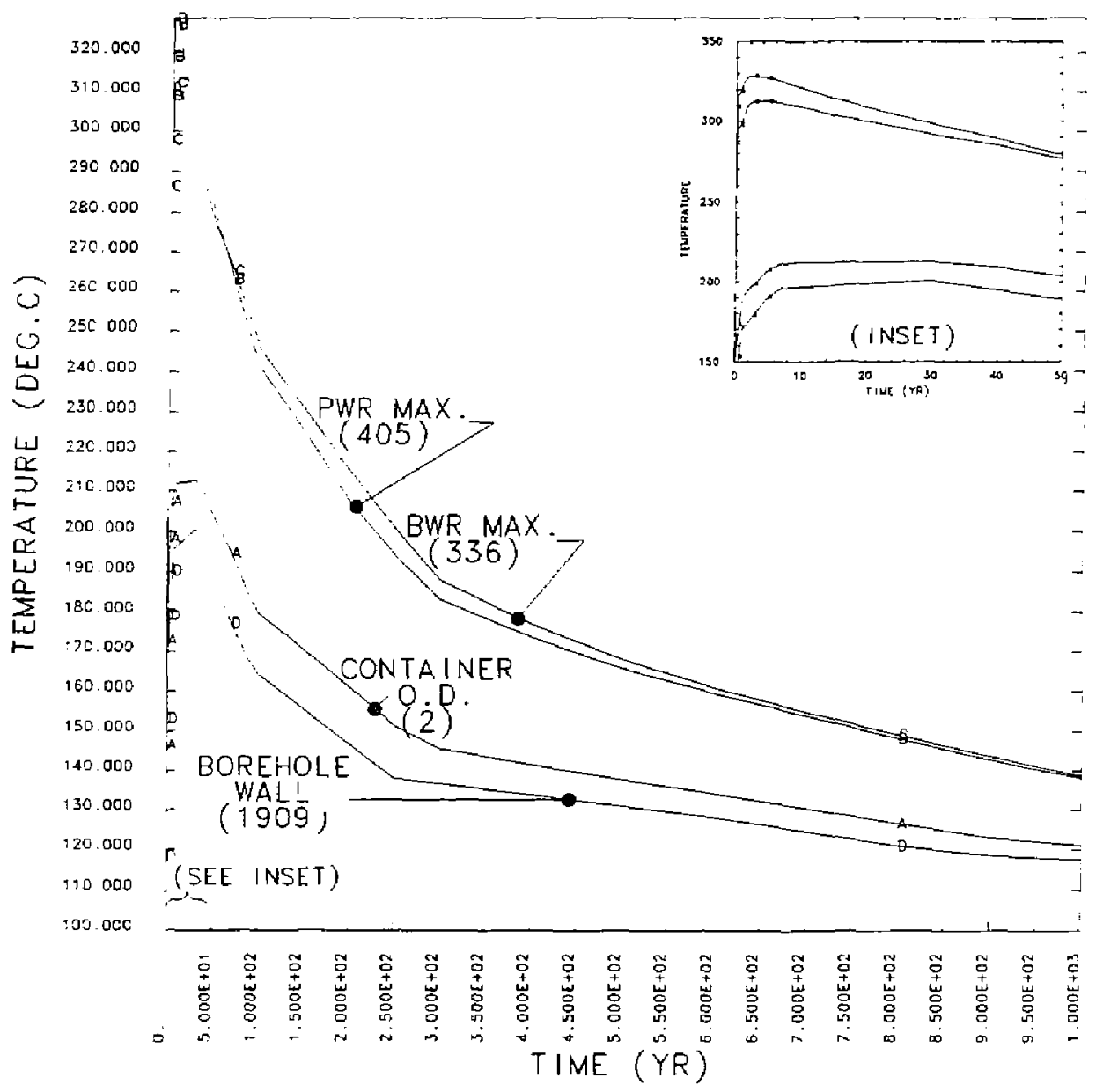

Figure 12. The peak temperature of the fuel cladding for the 304SS structure case is $329^{\circ} \mathrm{C}$. It occurs at about $3 \mathrm{yr}$ after emplacement. 
NNWS I HYB(3PWR4BWR) SS304 CONTAINER/1OYR-NORMAL BASE CASE $112 / 18 / 87$ GLJ

$T\rfloor M E=3.80000 E+00$ YEARS

T-BOREHOLE WALL $=190$ DEG.C

$4.000 E-0, \quad L$

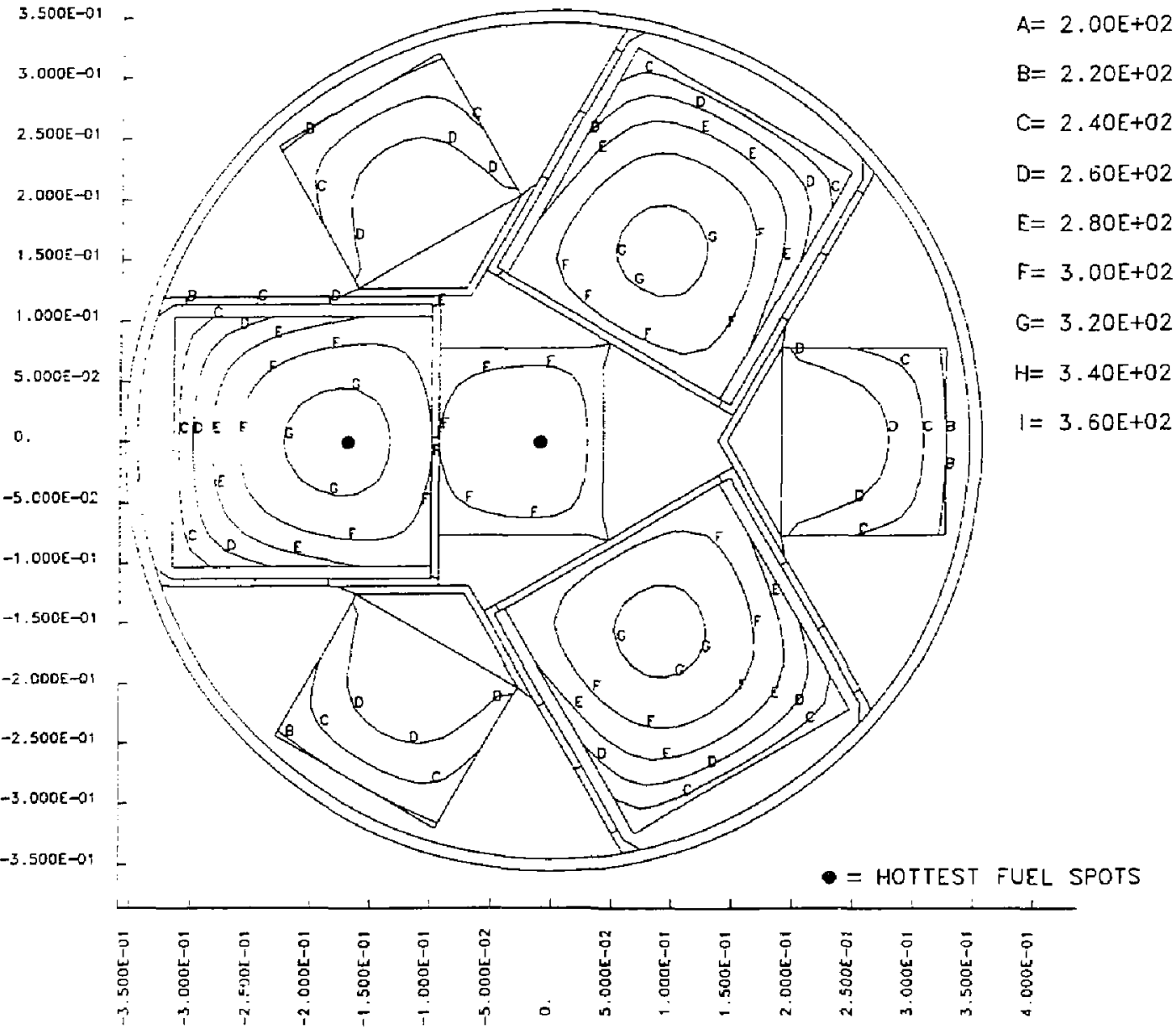

Figure 13. Isotherms for the $3045 S$ case at about 3 yr after emplacement show the peak cladding temperatures occur near the center of the leftmost PWR and central BW/R fuel canisters.

$\operatorname{MiN}(-)=7.84 \mathrm{E}+02$
$\operatorname{MAX}(+)=3.28 \mathrm{E}+02$

CONTOUR LEVELS

TEMPERATURE (DEG.C)

$$
\begin{aligned}
& A=2.00 E+02 \\
& B=2.20 E+02 \\
& C=2.40 E+02 \\
& D=2.60 E+02 \\
& E=2.80 E \div 02 \\
& F=3.00 E+02 \\
& G=3.20 E+02
\end{aligned}
$$




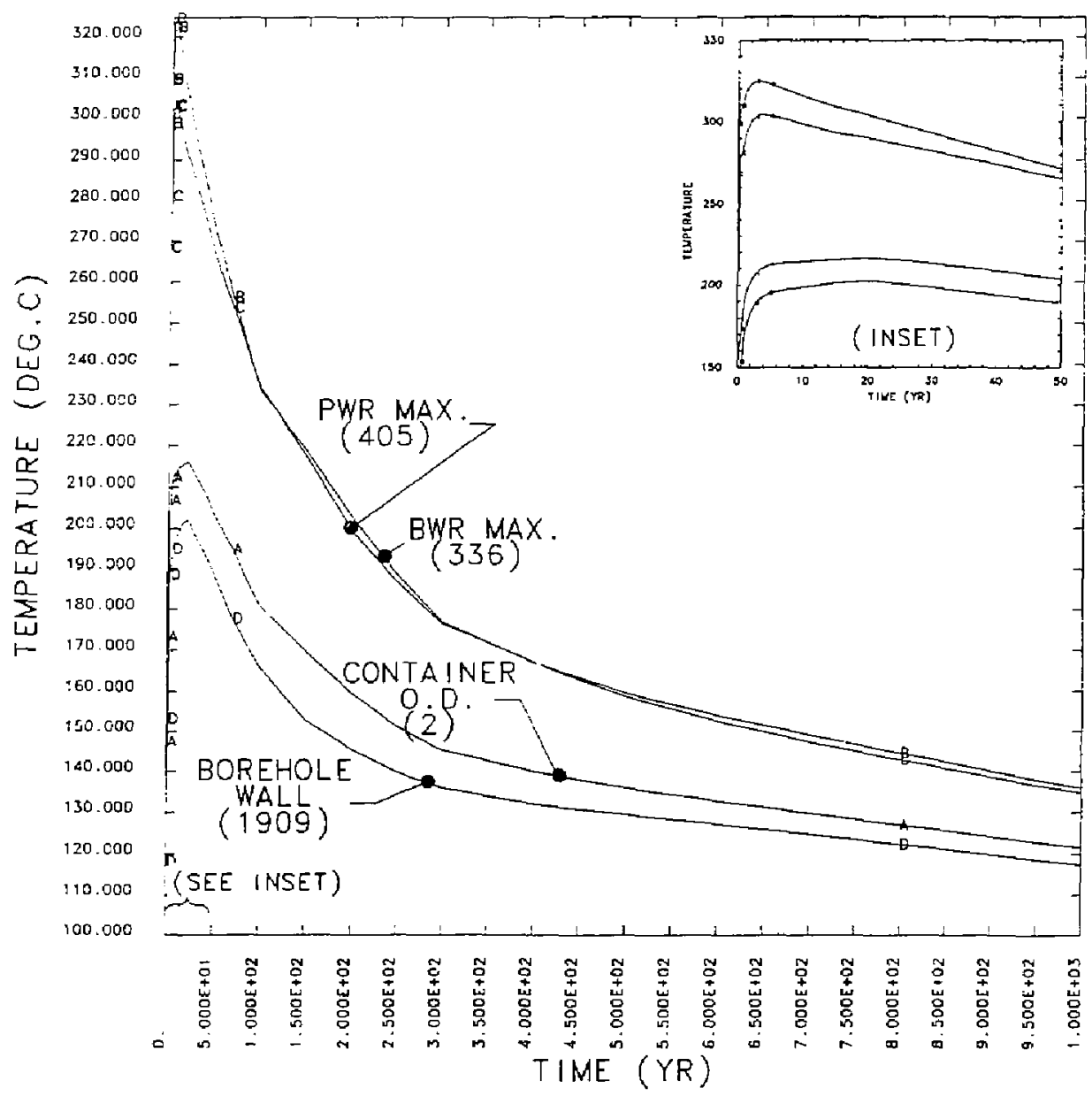

Figure 14. The peak temperature of the fuel cladding for the 7030 structure case, $325^{\circ} \mathrm{C}$, occurs about 3 yr after emplacement. 


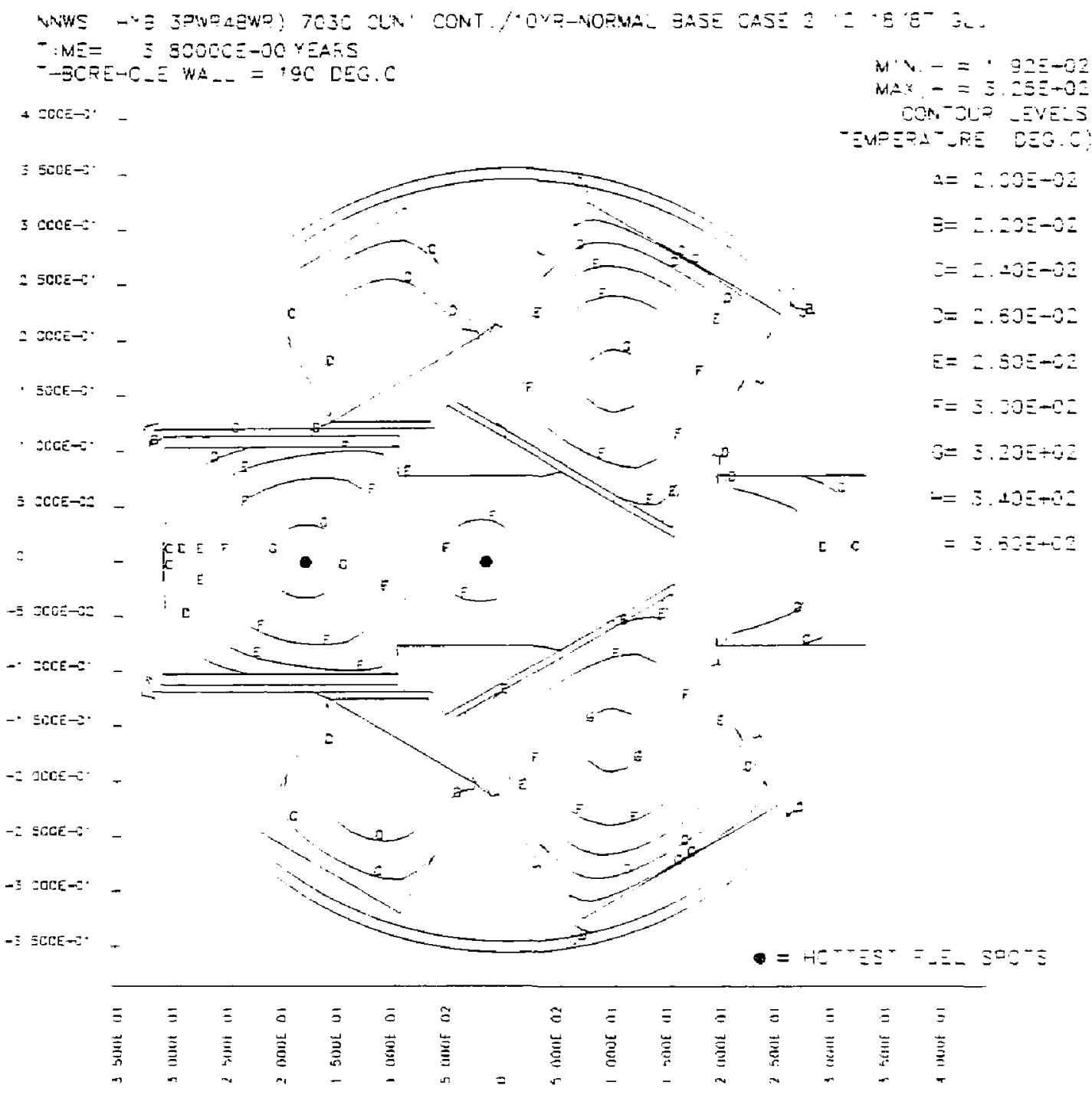

Figure 15. Isotherms fo: the 7030 case at about 3 yr after emplacenent show the central BWR box is muct cooler than the 304SS case. 


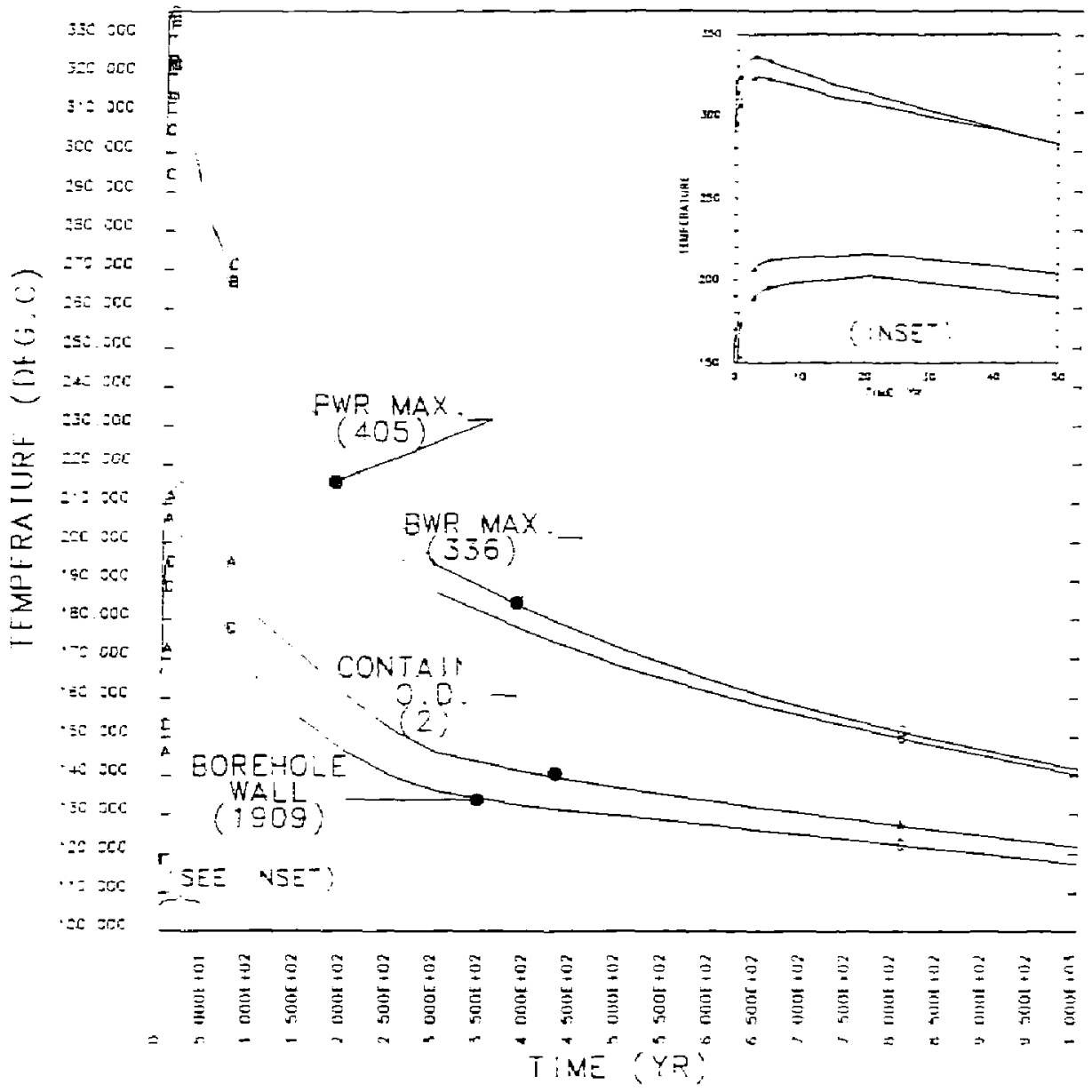

Figure 16. The peak temperature of the fuel cladding for the IN825 structure case (2-D Reference Case) is $336^{\circ} \mathrm{C}$. 


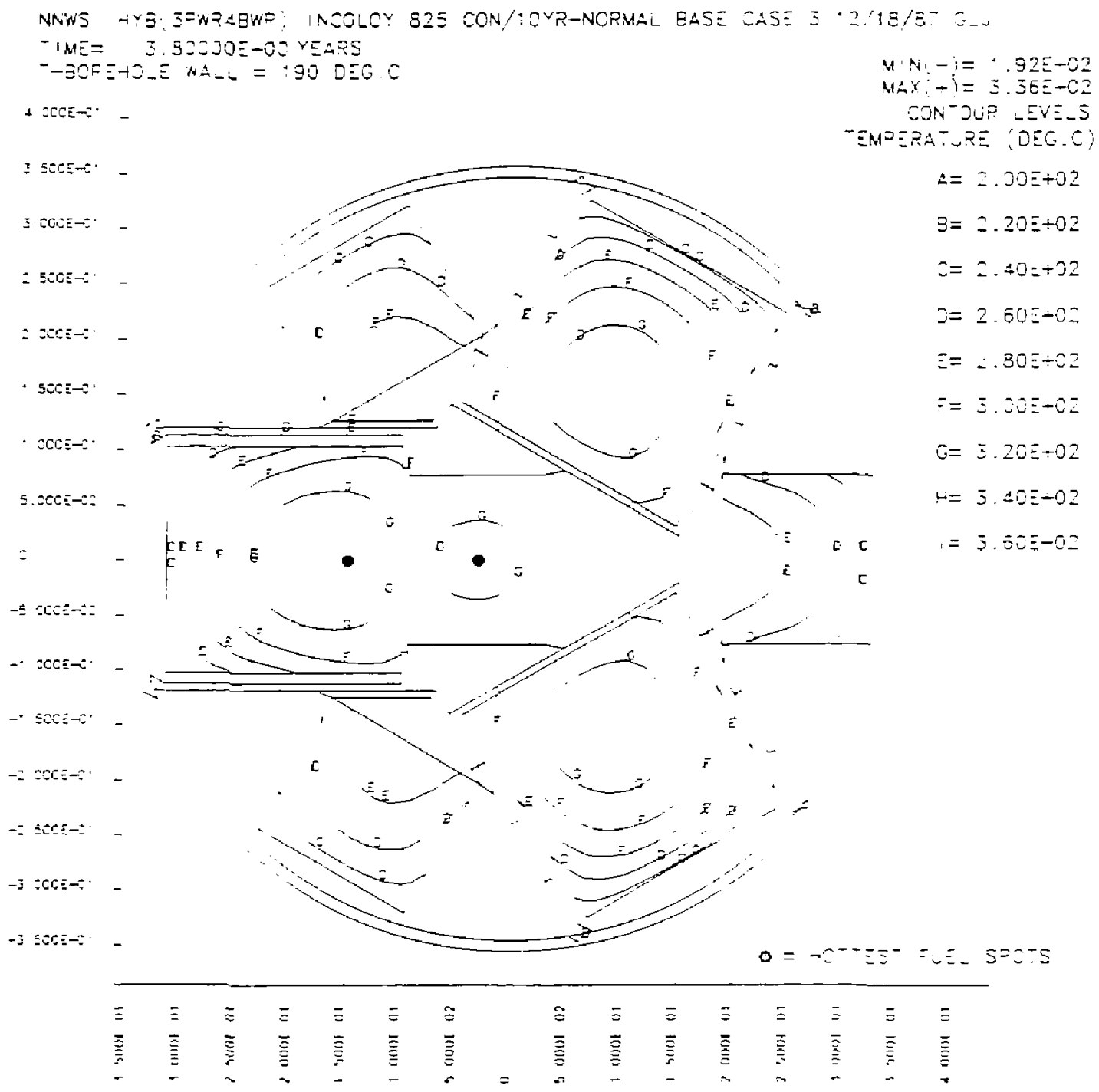

Figure 17. Isotherms for the IN825 case at about 3 yr after emplacement. 


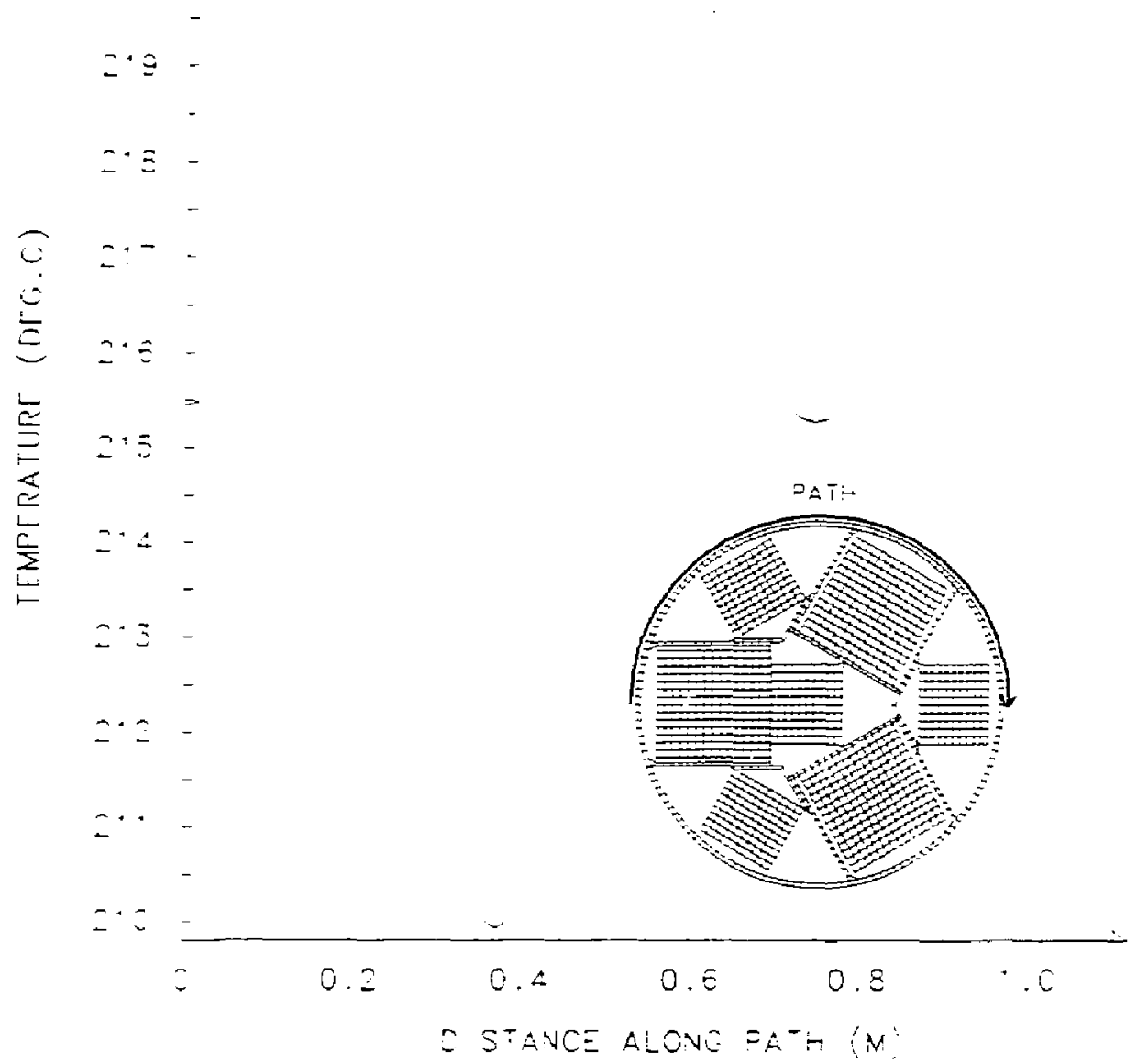

Figure 18. The surface temperature of the container may vary by as much as $10^{\circ} \mathrm{C}$ between adjacent hot and cool spots. 


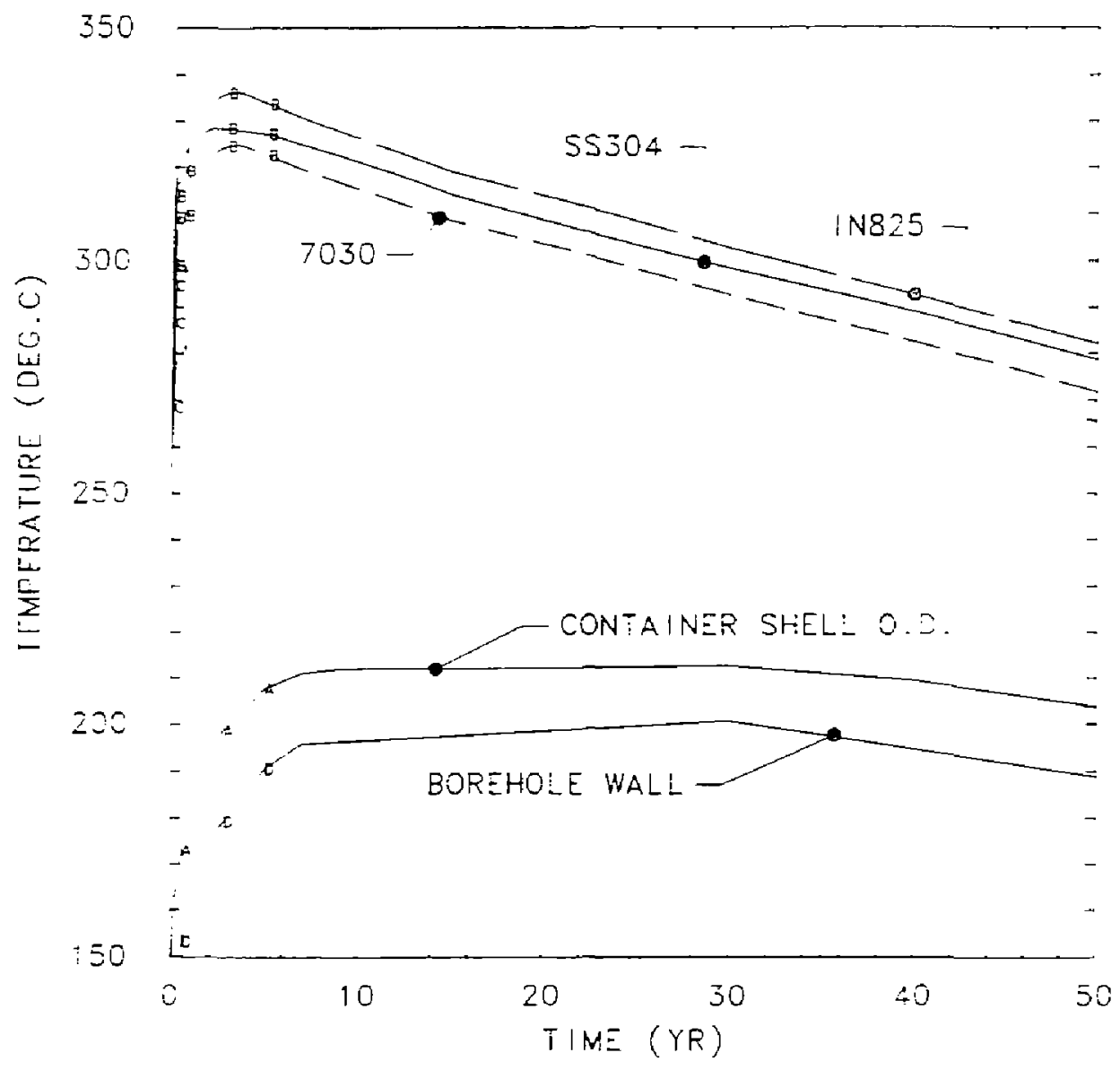

Figure 19. The effect of structural material choice is small, indicating that most of the heat is transferred to the shell by thermal radiation. 


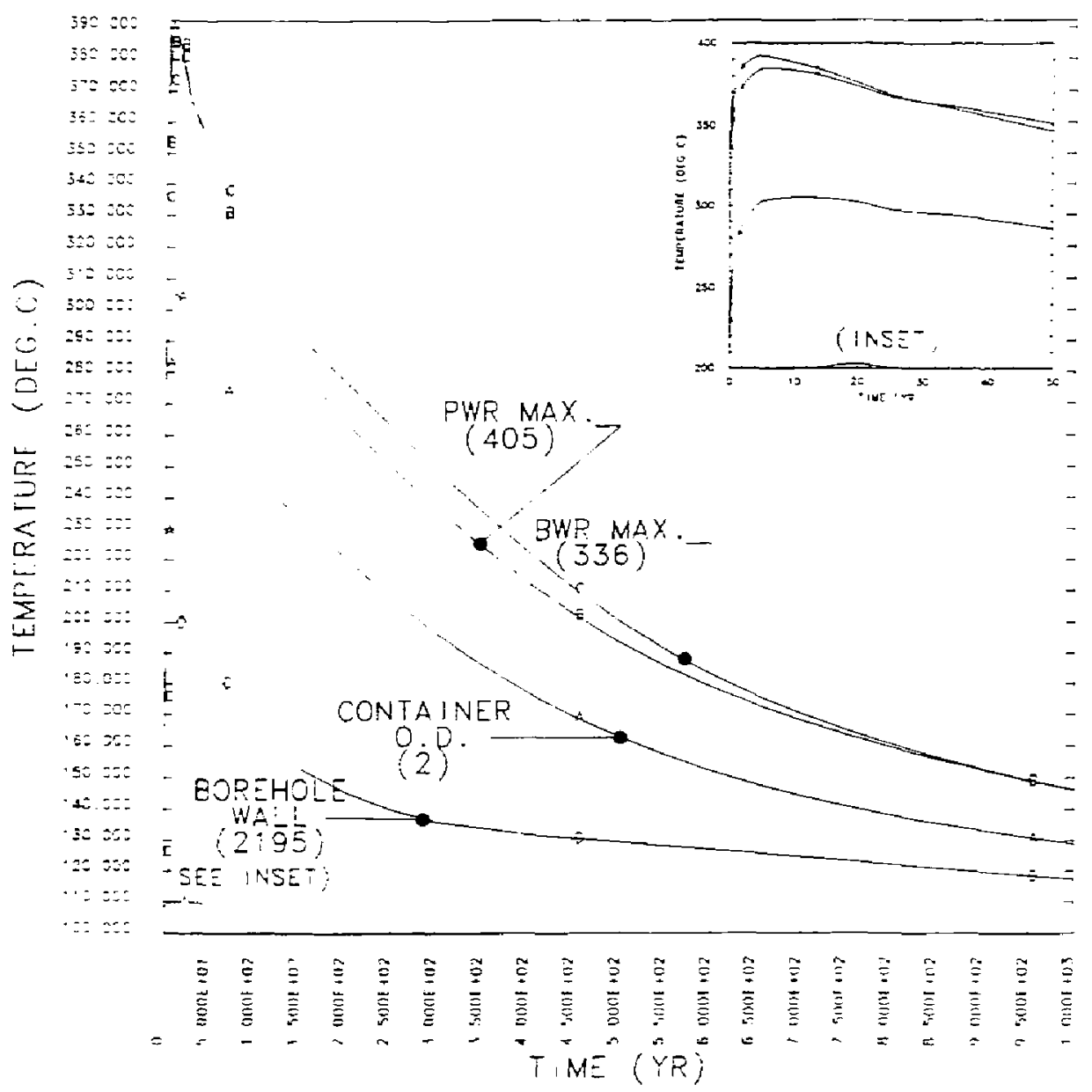

Figure 20. The peak temperature of the fuel cladding for the loose backfill case in annulus is $391^{\circ} \mathrm{C}$, occurring abous 5 yr after emplacement. 
NWS, -YB:3=WR4BWR; INCOLOY 825 CONT/IOYR-OVERPK BASE CASE $4: 2 / 18 / 87$ GL

- ME $=\quad 5.05000 E-00$ YEARS

T-EOFE UOLE WA_E = 204 DEG.

MIN $(-)=1.95 E \div 02$

$M A X(+)=3.92 E+02$

CONTOLR LEVELS

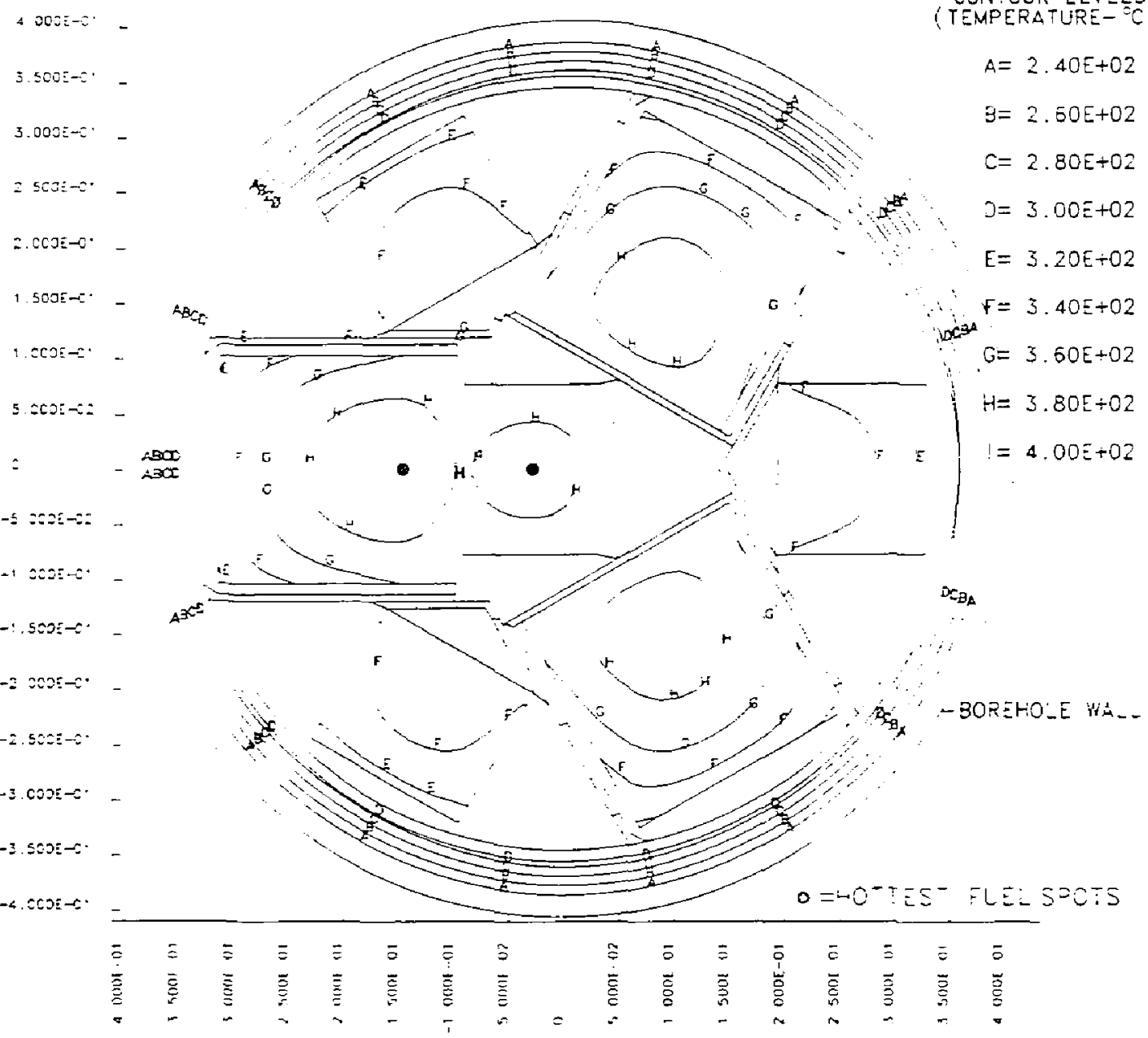

Figure 21. Isotherms for the loose backfill case at about $4 \mathrm{yr}$ after emplacement. 
NNWFSE(3PWR4BWR) INCOLOY 825 CONT/10YR-BETNPK BASE CASE $1412 / 18 / 87$ GL

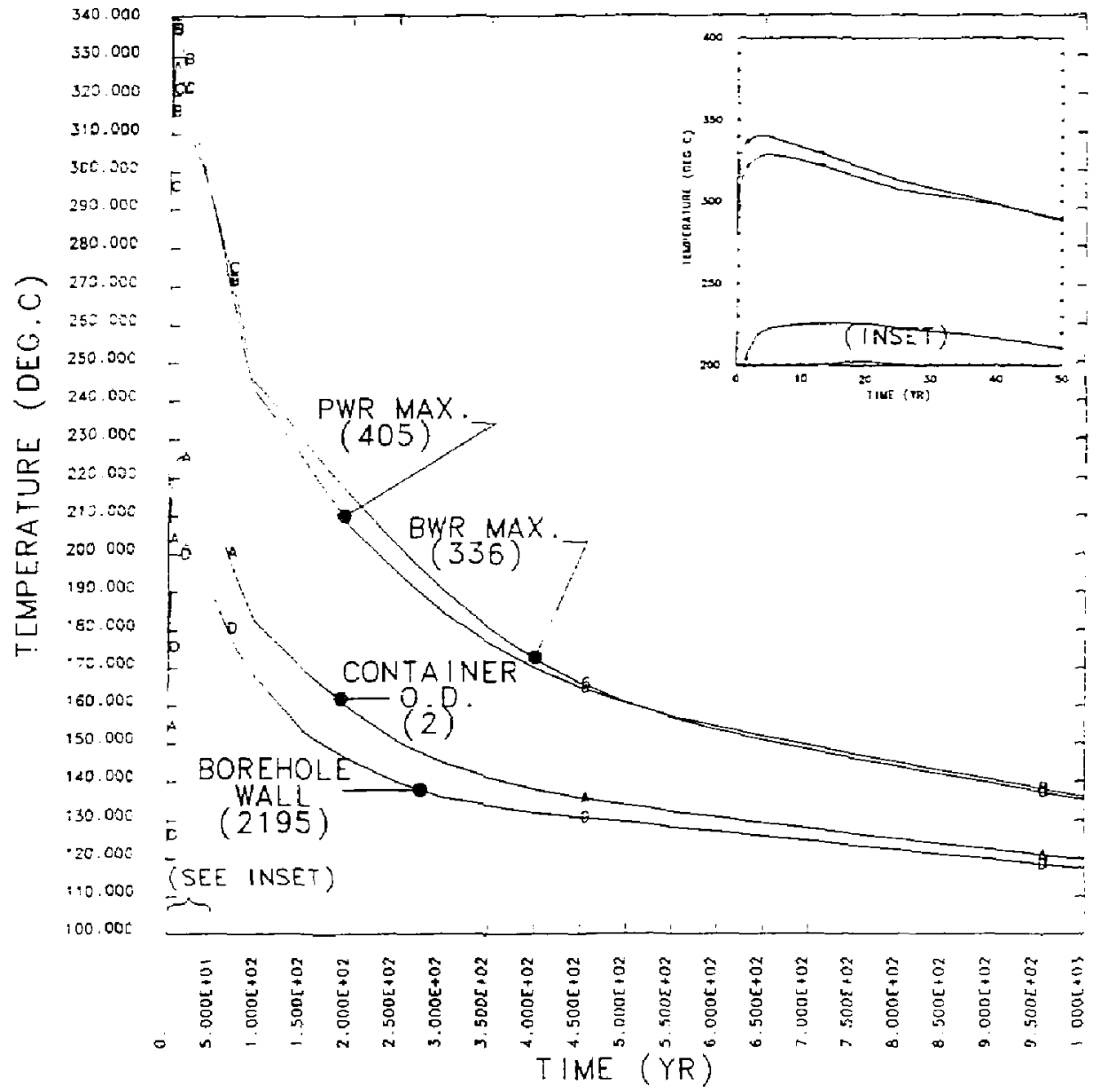

Figure 22. The peak temperature of the iuel cladding for the firm backfill case is $341^{\circ} \mathrm{C}$, occurring about $4 \mathrm{yr}$ after emplacement. 
NNWS: HYB(3PWR4BWR) INCOLOY 825 CONT/IOYR-BETNPK BASE CASE14 12/18/87 GL

TIME $=5.05000 E+00$ YEARS

T-BOREHOLE WALL $=$-96 DEG.C

$M ! N(-)=1.95 E+02$

$\operatorname{MAX}(+)=3.40 E+02$

CONTOUR LEVELS

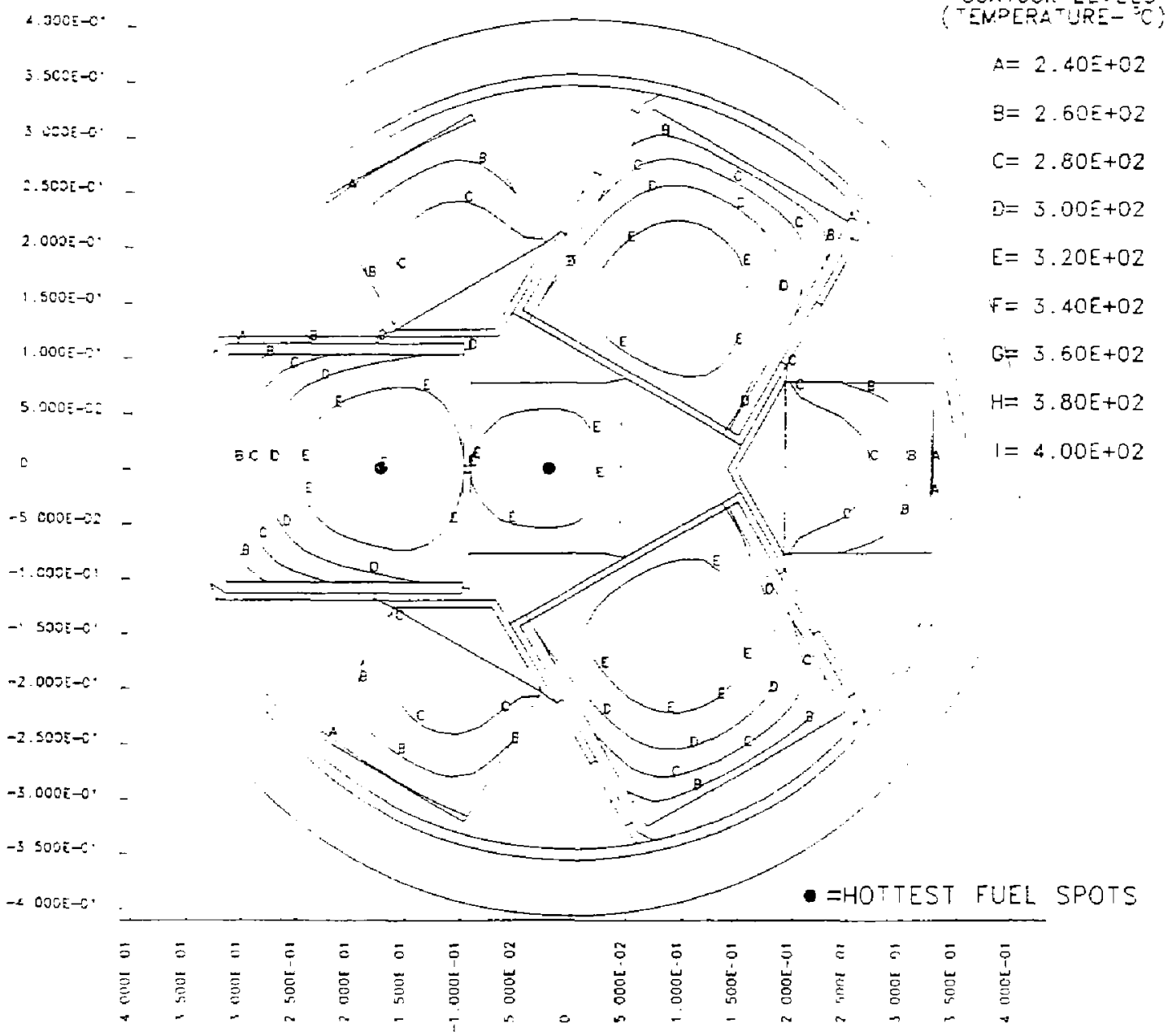

Figure 23. Isotherms for the firm backfill case at about $5 \mathrm{yr}$ after emplacement. 


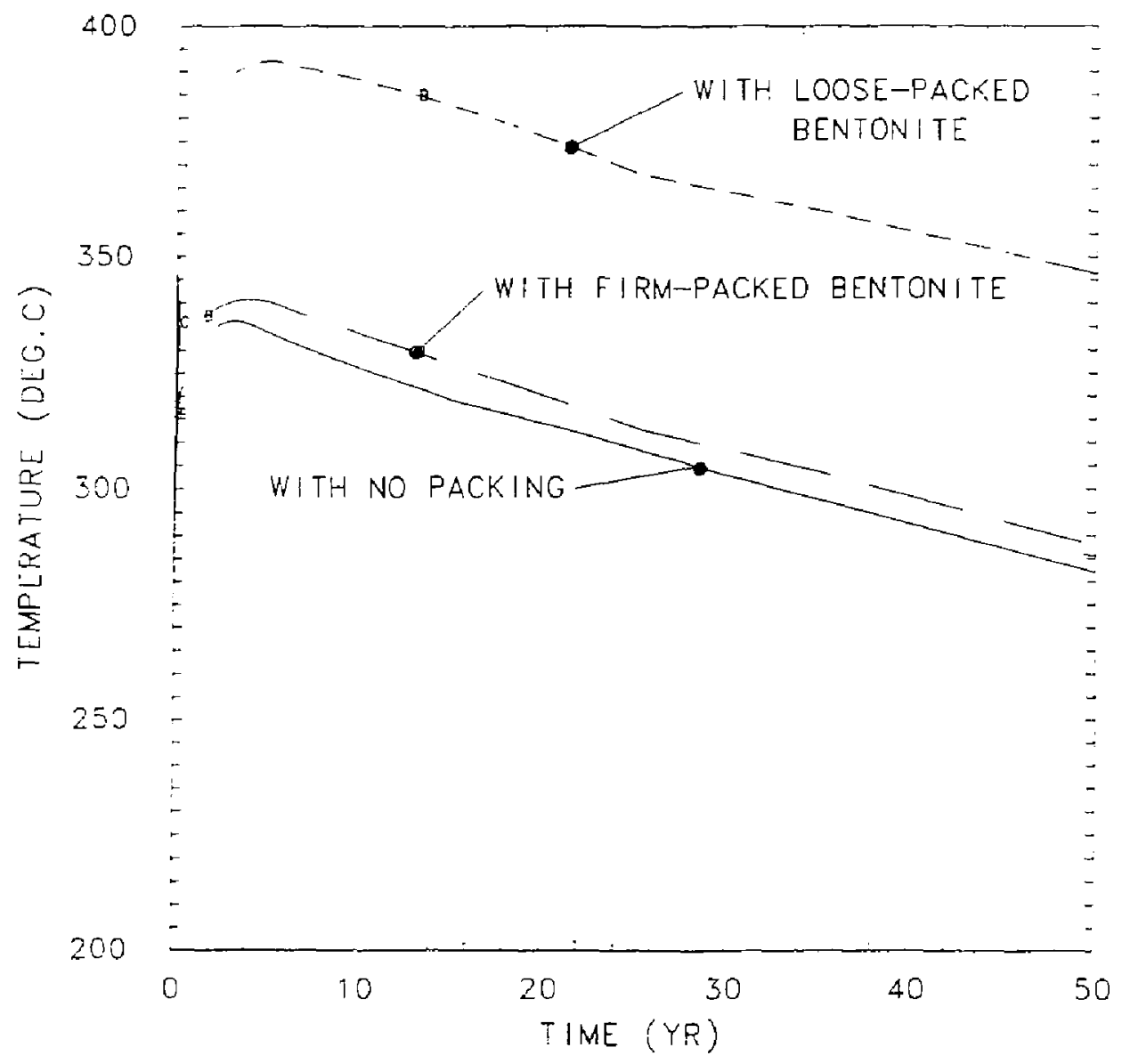

Figure 24. Eackit!ling the annulus with loosely packed bentonite raises the peak temperatures over $50^{\circ} \mathrm{C}$ above the case with no backfill. Backfilling the annulus with firmly packed bentonite only raises the peak temperatures by about $5^{\circ} \mathrm{C}$. 


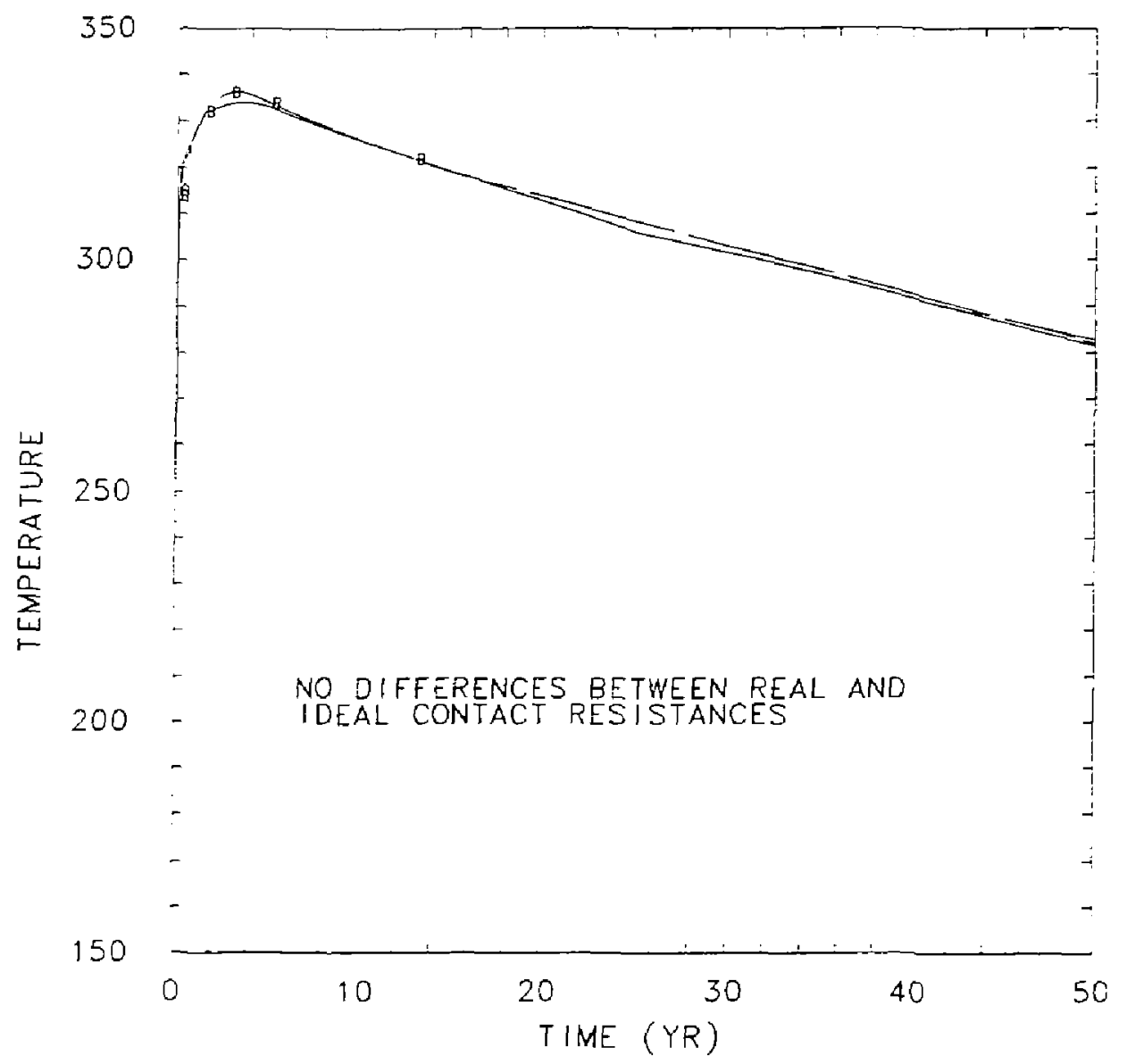

Figure 25. Using realistic contact thermal resistances rather than ideal values does not change the peak temperatures. 
HYBR 18(3PWR4BWR) INCOLOY 825 CONT./5YR-NORMAL CASE $61 / 18 / 88$ GLJ-TACO

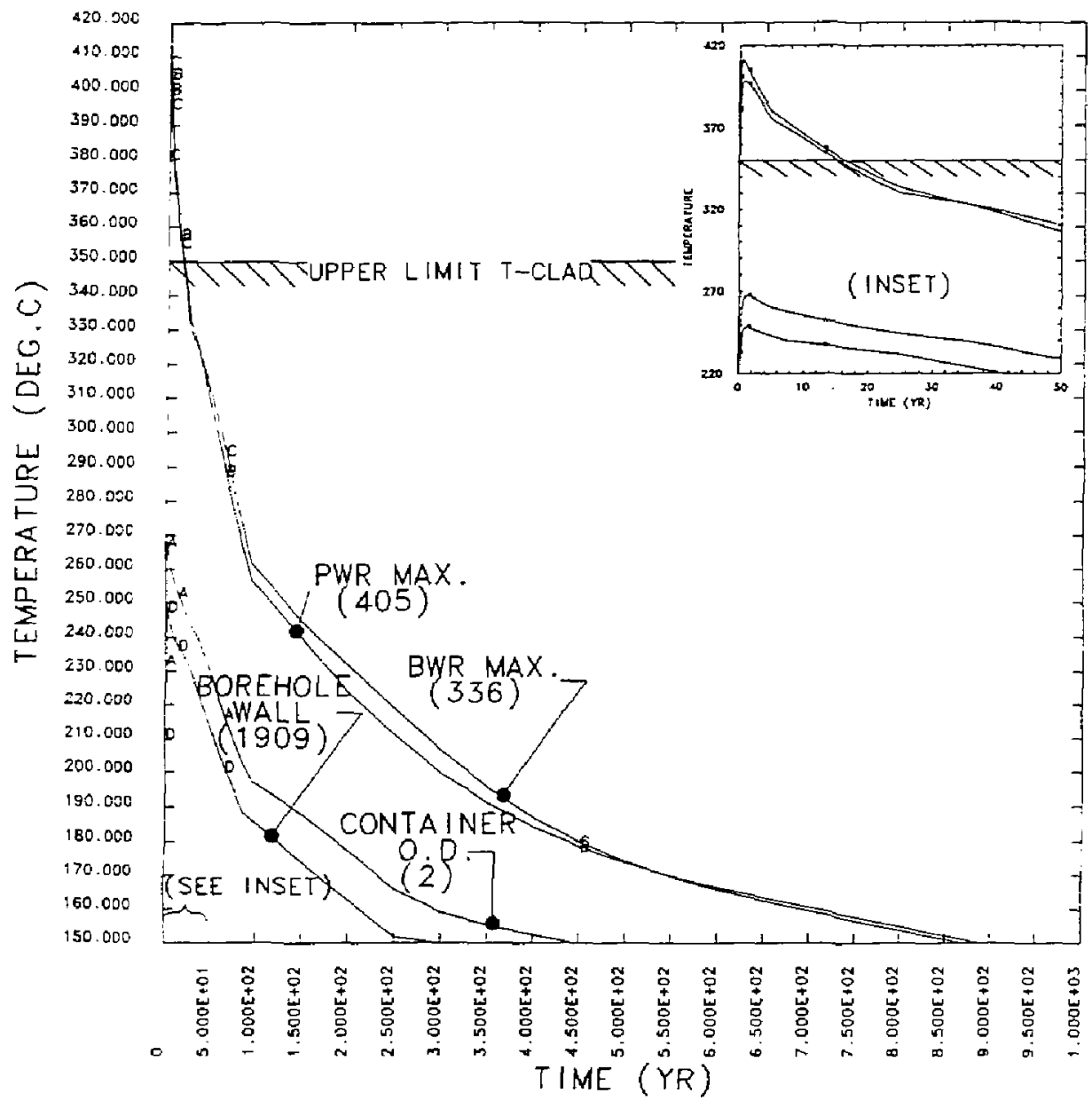

Figure 26. The peak temperature of the fuel cladding for the 5-year fuel case, $411^{\circ} \mathrm{C}$, occurs about 8 months after emplacement. 
NNWS 1 HYB(3PWR4BWR) INCOLOY 825 CONT./5YR-NORMAL CASE 6 1/18/88 GL1-TACO

TIME $=6.50000 E-01$ YEARS

T-BOREHOLE WALL $=248$ DEG.C

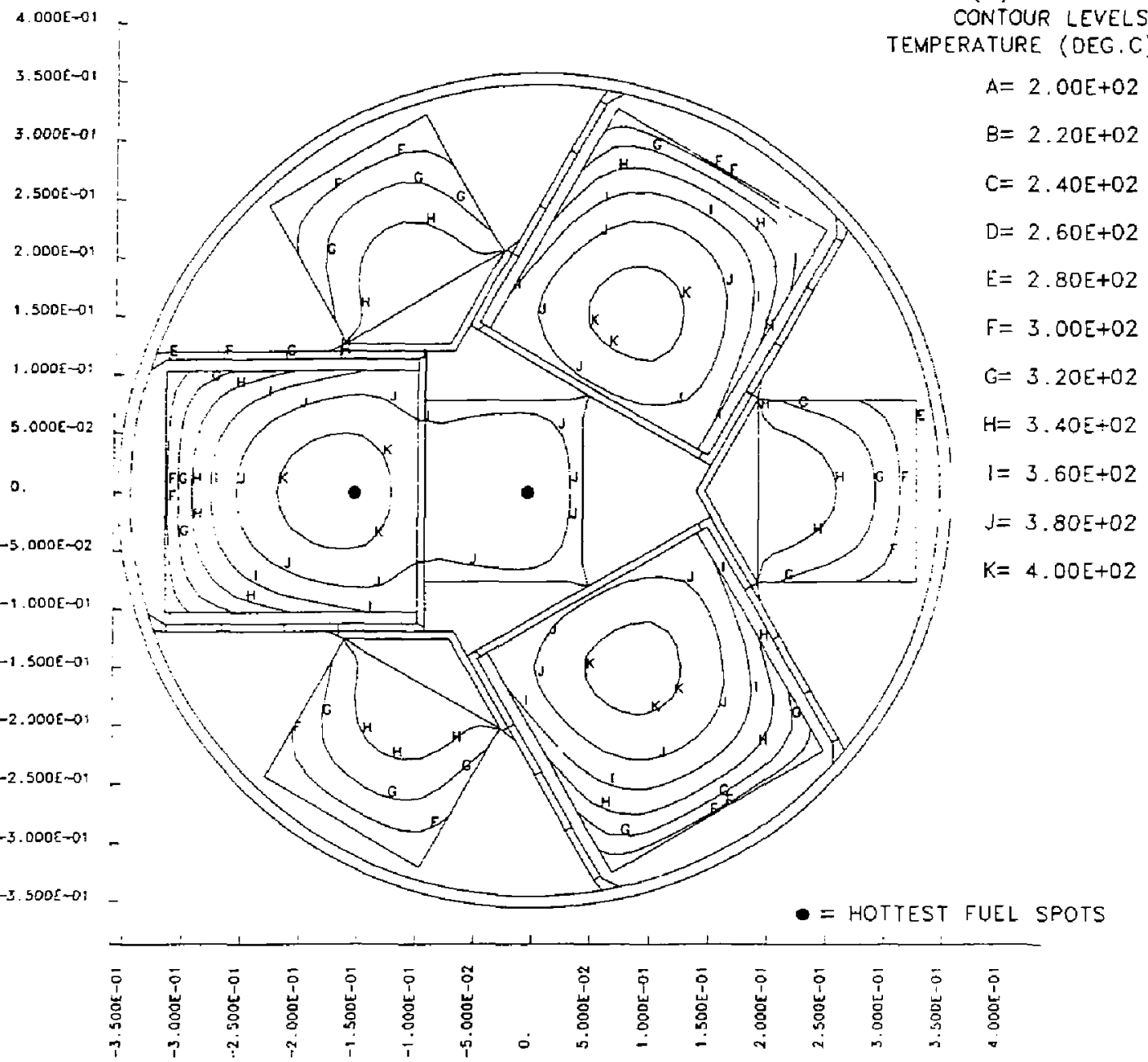

$\operatorname{MIN}(-)=2 \cdot 46 E+02$

$\operatorname{MAX}(+)=4.11 E+02$

CONTOUR LEVELS

$A=2.00 E+02$

$B=2.20 E+02$

$=2.40 E+02$

$D=2.60 E+02$

$$
02
$$


HYBRIB(3PWR 4BWR) INCOLOY 825 CON/1OYR-0.5 EMISSIV CASE $712 / 18 / 87$ GLJ

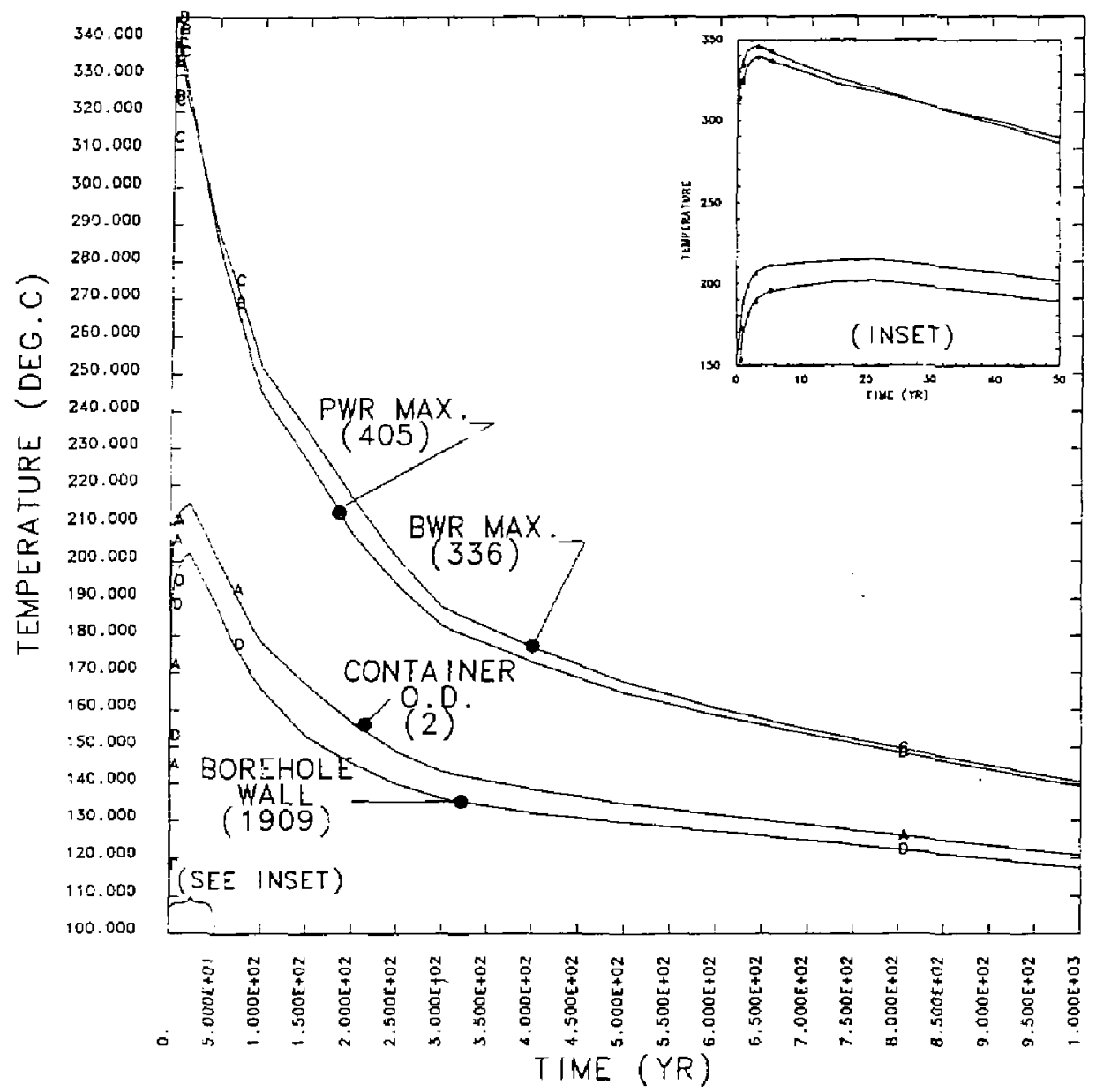

Figure 28. The peak temperature of the fuel cladding for the emissivity case with its lower emissivity on the inside surfaces is $346^{\circ} \mathrm{C}$. 

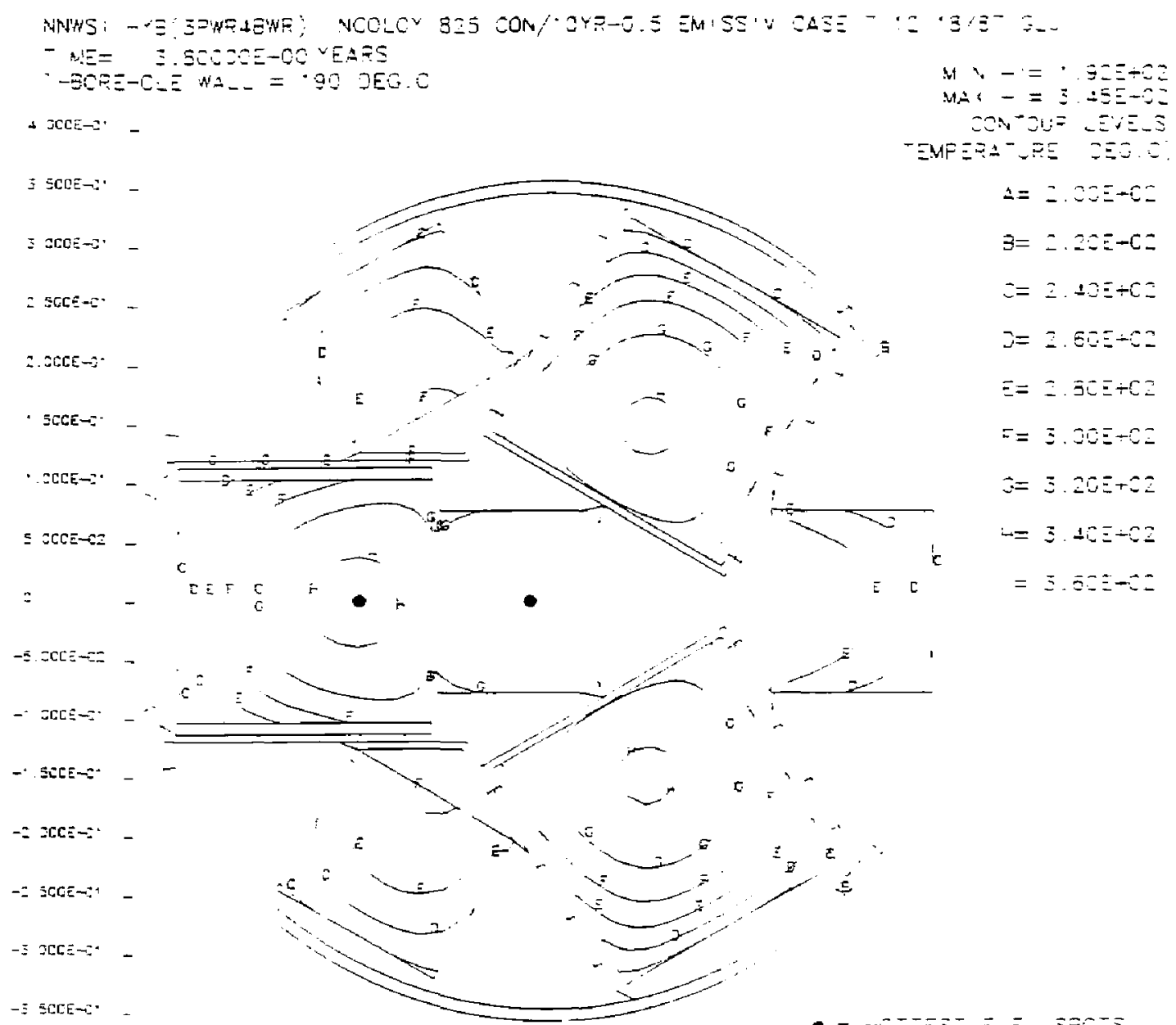

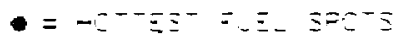

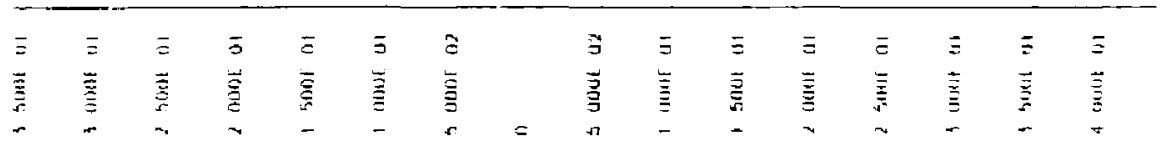

Figure 29. Isotherms for the emissivity case near the time of peak temperature show sharper gradients in structure than in the peference case. 


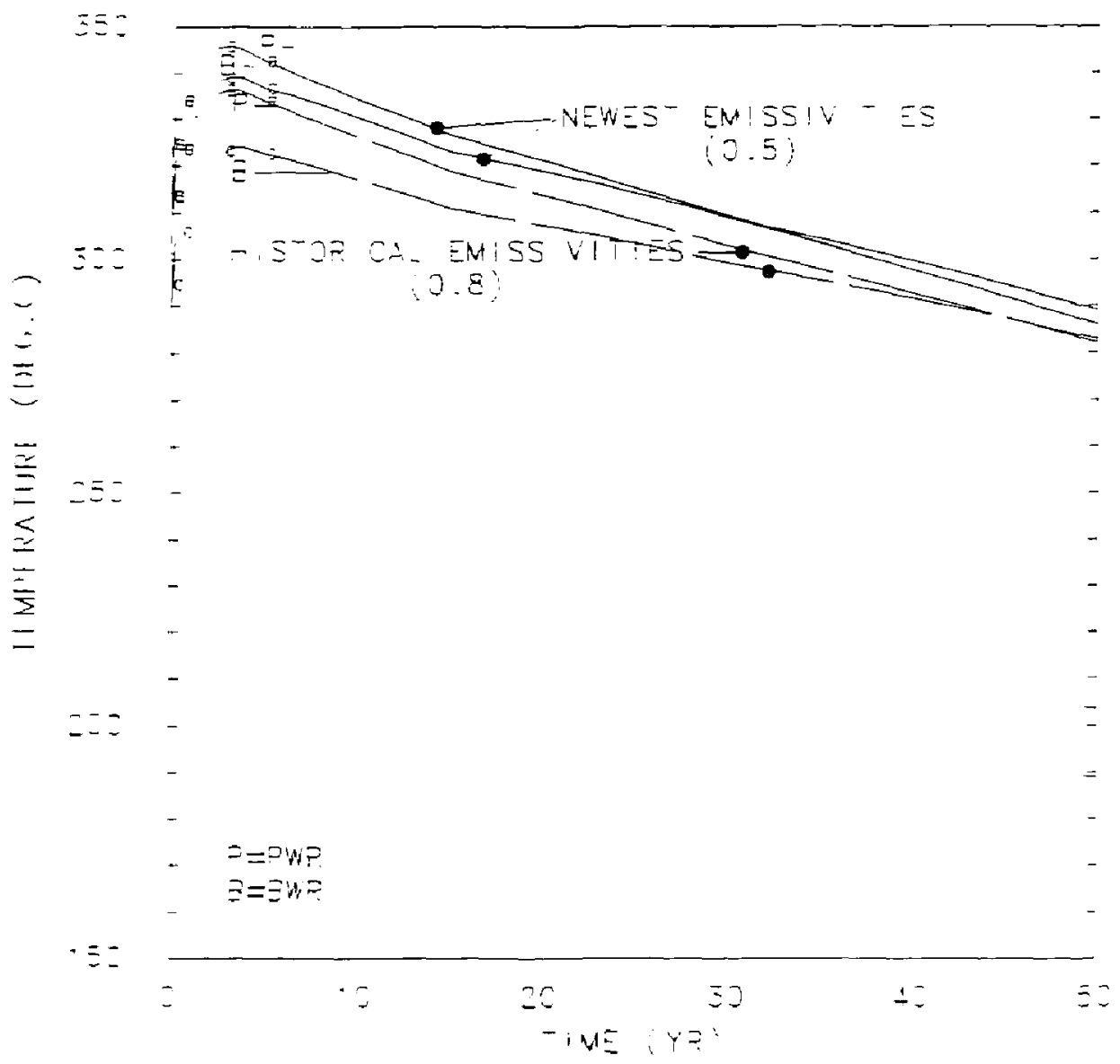

Figure 30. When compared with the reference case, the peak temperatures increase by as much as $10^{\circ} \mathrm{C}$ by assuming the lower emissivity for the inside surtaces. 


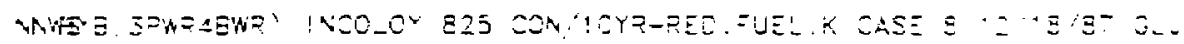

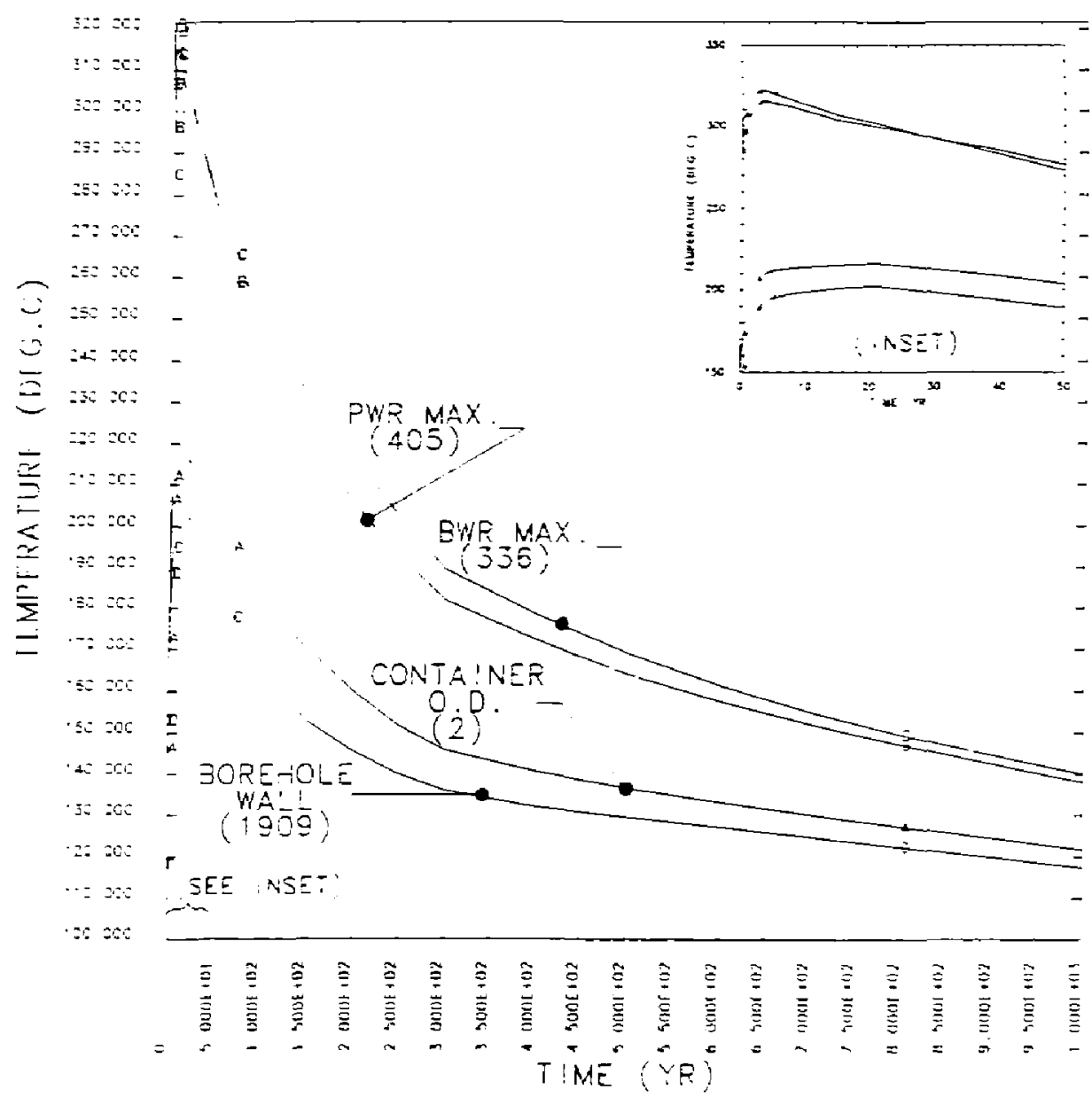

Figure 31. The peak temperature of the fuel cladding for the case with increased fuel conductivity is $322^{\circ} \mathrm{C}$. 


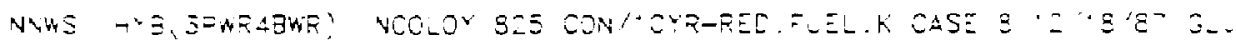

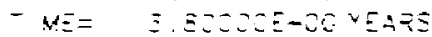

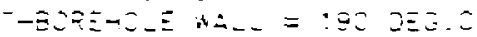

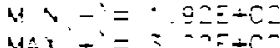

$M A-C=2 Z E+C=$

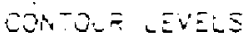

$+3 \cdot \sin ^{\circ}$

- EMVEFA-URE (2EO.C)

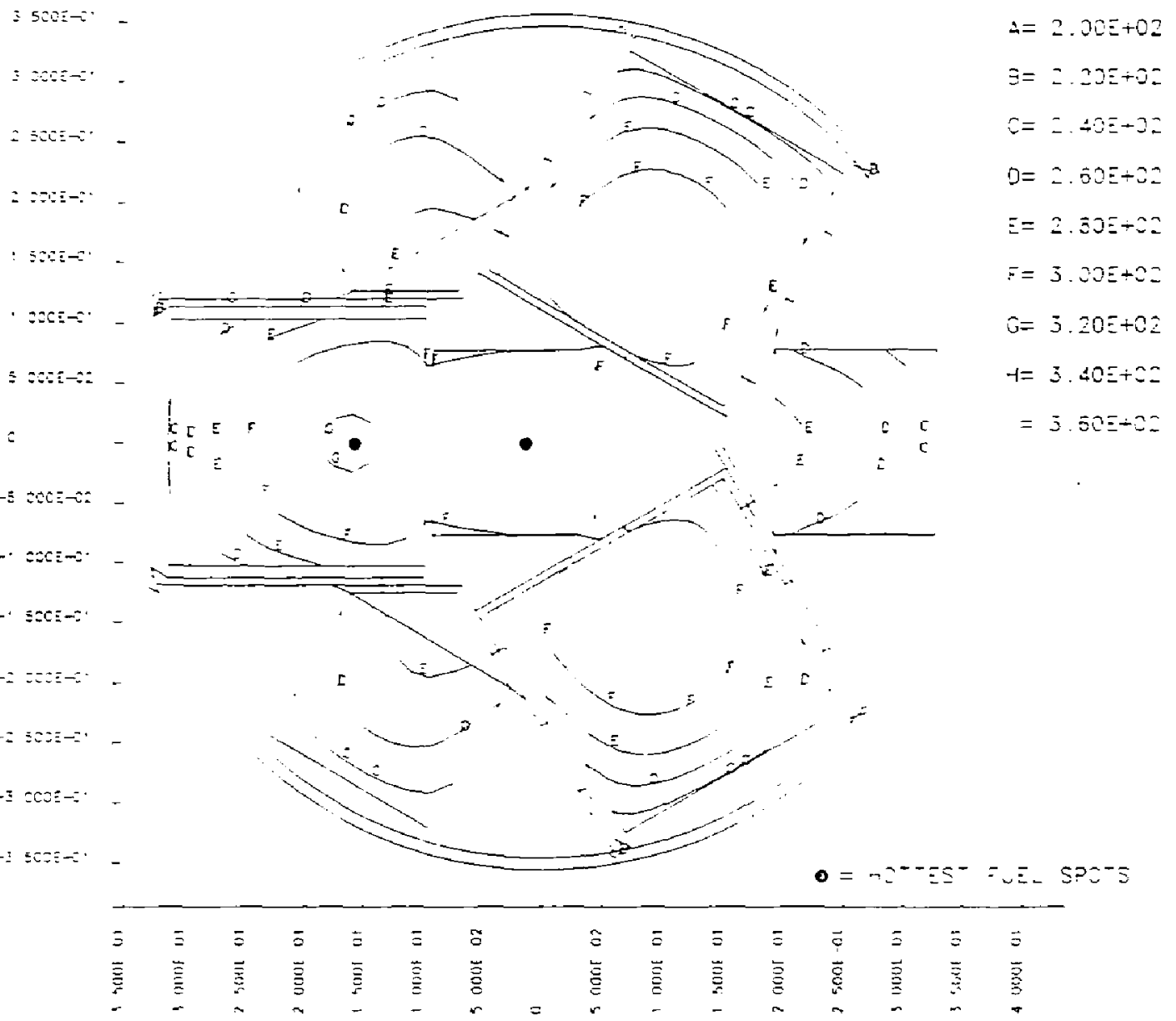

Figure 32. Isotherms for the fuel conductivity case show much less temperature gradient in the fuel canisters. 


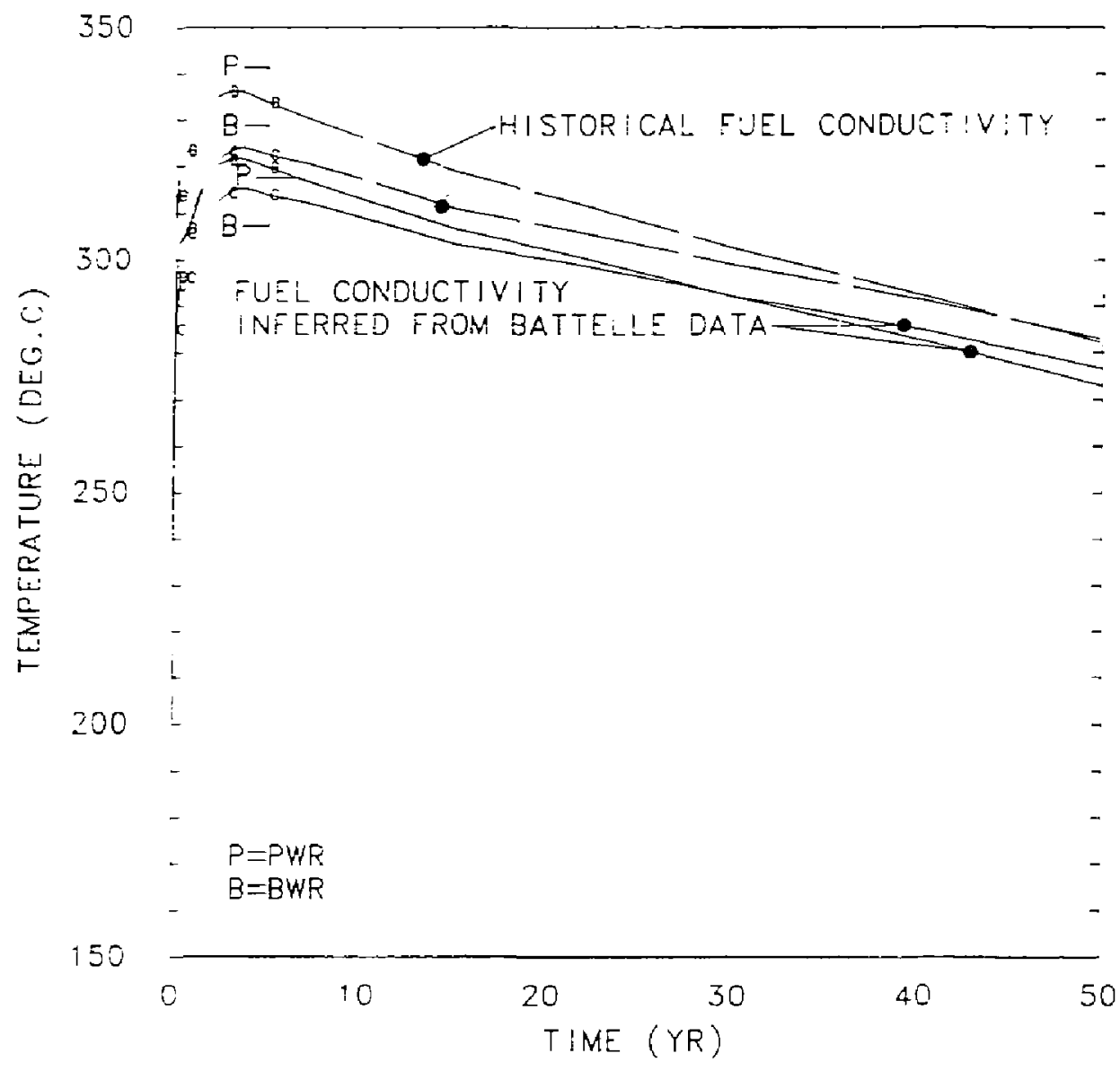

Figure 33. The use of fuel pack therma! conductivities derived from Battelle's measured fuel bundle temperature profiles longers the peak cladding temperatures by 8 to $15^{\circ} \mathrm{C}$. 
NNWSE(3PHRAEWR) INCOLOY 825 CON/ OYY-NORMAL GASFL CASE $92 / 15 / 88$ GLJ

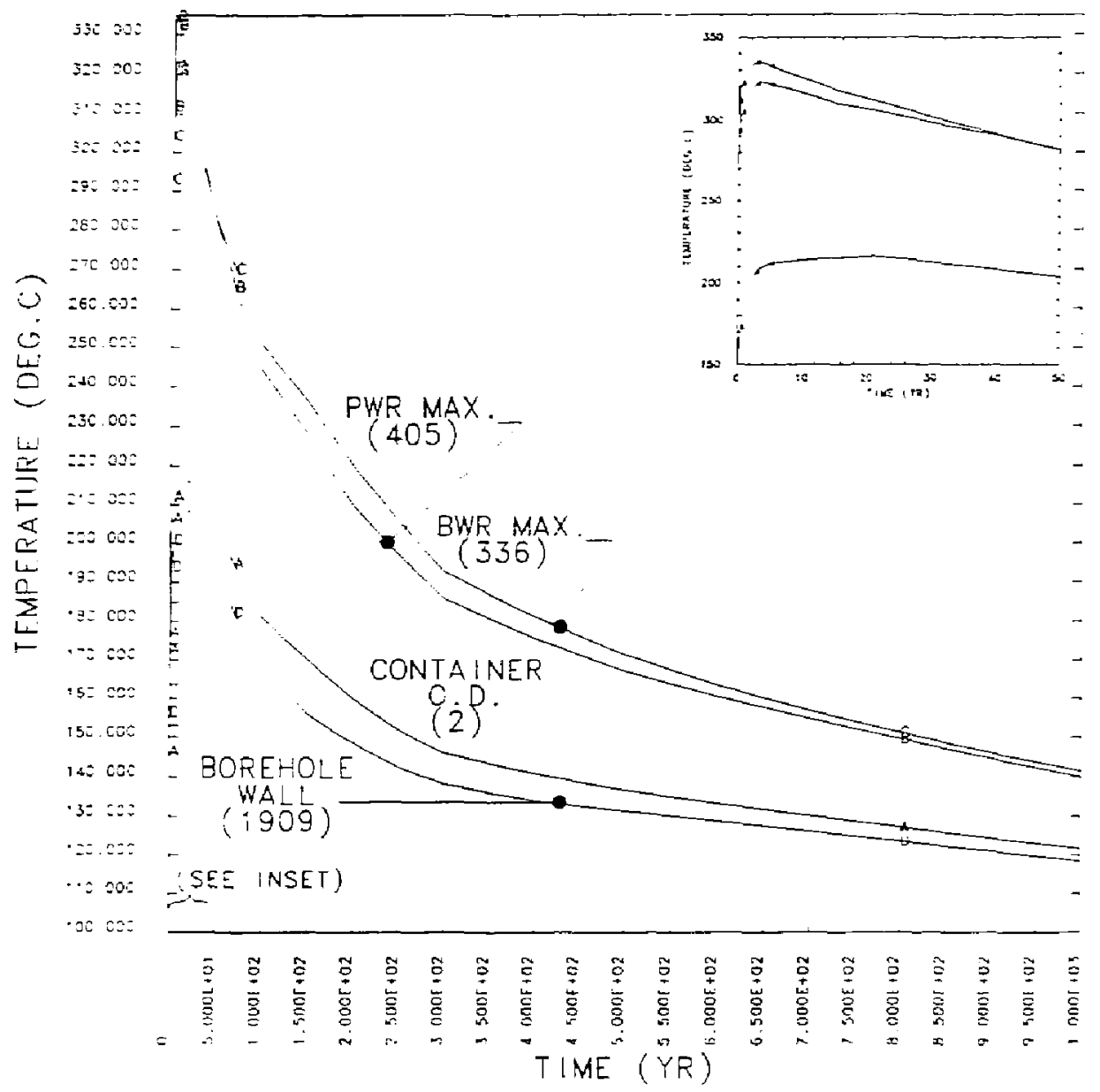

Figure 34. The peak temperaiurn of the fuel cladding for the gas fill case is $335^{\circ} \mathrm{C}$. Thermal radiation is still the predominant heat transier mode. 


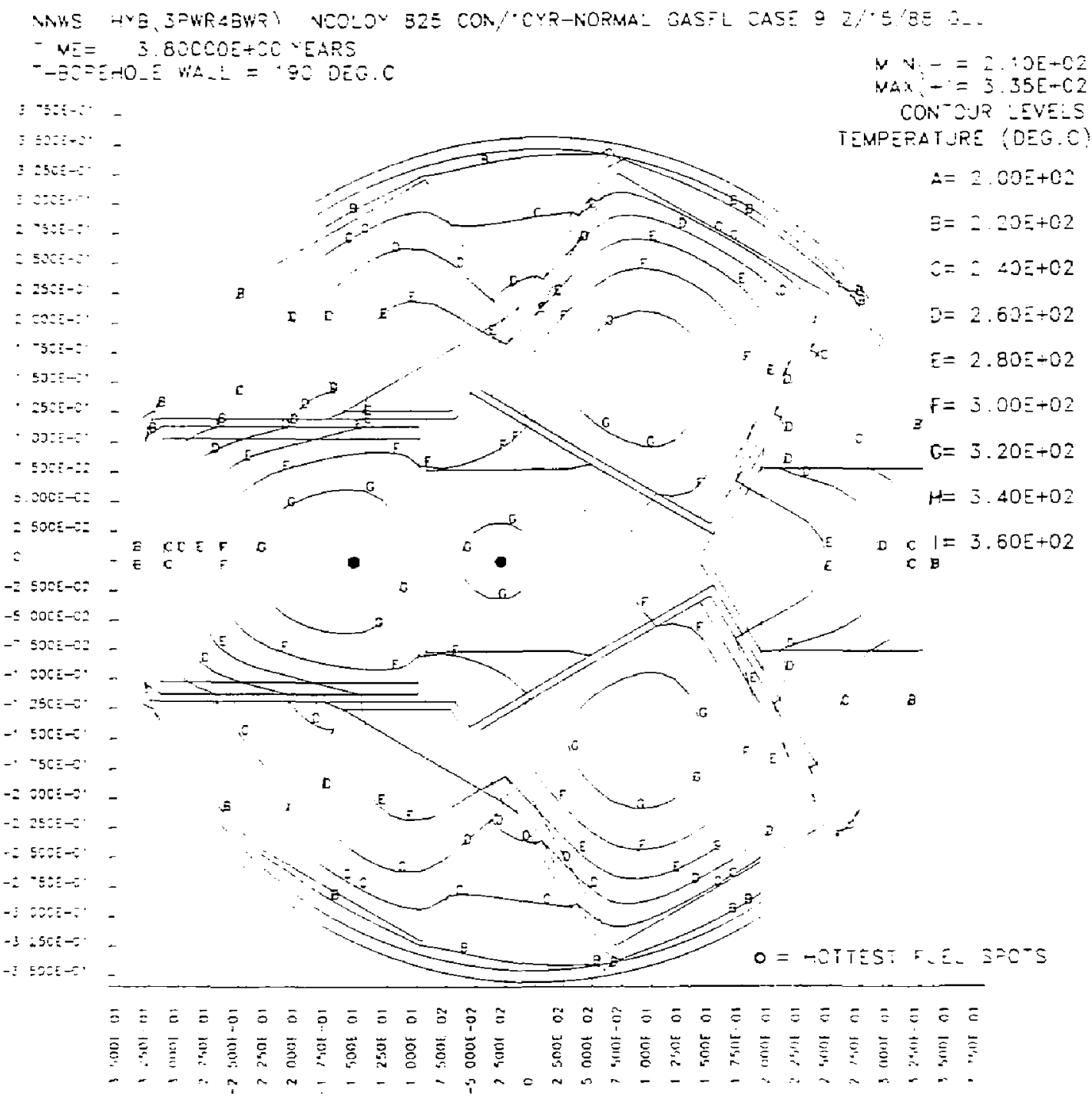

Figure 35. Isotherms for the gas fill case at about $3 \mathrm{yr}$ after emplacement. 
NNWSYE (3PWR 4BWR) INCOLOY 325 CON/10YR-NORMAL BEST CASE $102 / 15 / 88$ GLJ

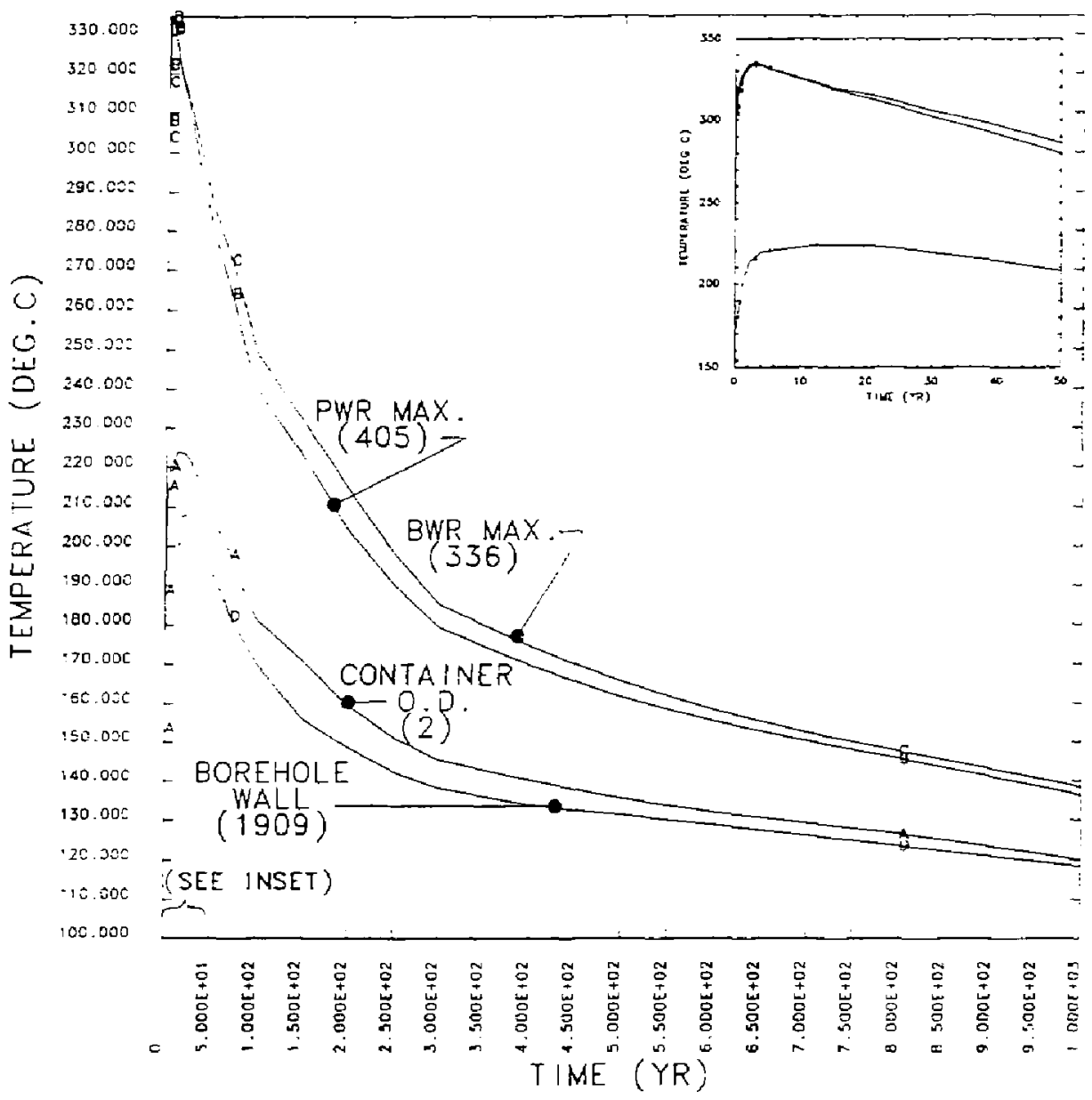

Figure 36. The peak temperature of the fuel cladding for the "best model" analysis including: tine-zoned mesh of iuff, improved fuel conductivity, 0.5 internal surface emicsivity, and gas-fill conduction, is $336^{\circ} \mathrm{C}$. 
NWWS: FB(3PWFG3WF) INCOLOY 825 CON/:OYR-NORMAL BEST LASE $02315 / 88$ G.J

$T$ TME $=3.20000 E+00$ TEARS

:-BOREHOLE WALL $=198$ DEG.C
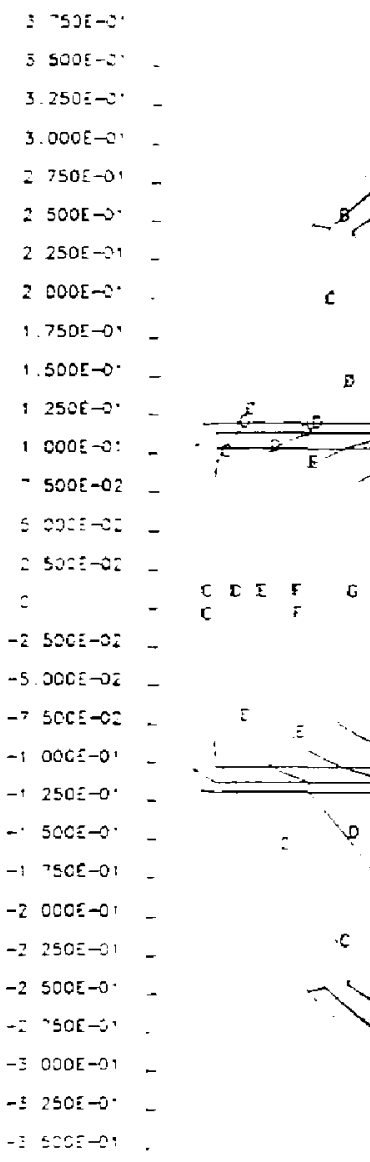

MIN(-) $=2.17 \vec{E}+02$ $\operatorname{MAX}(+)=3.36 \mathrm{E}+02$

CONTOUR LEVELS

TEMPERATURE (OEG.C)

$\Delta=2.00 E+02$

$B=2 \cdot 20 E+02$

$C=2 \cdot 40 E+02$

$D=2.60 E+O 2$

$E=2.80 E+02$

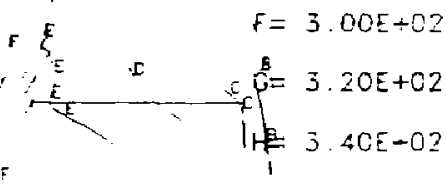

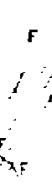

$\therefore \quad \mathbf{E}=3.60 E+02$
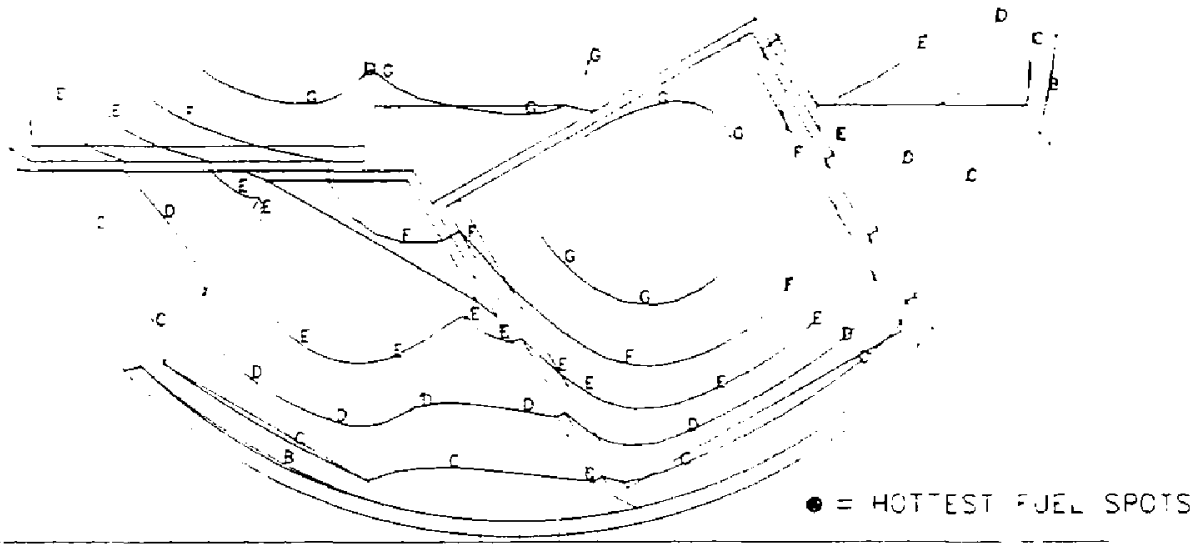

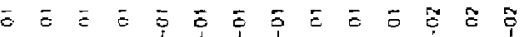

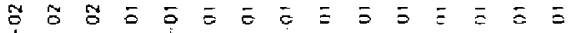

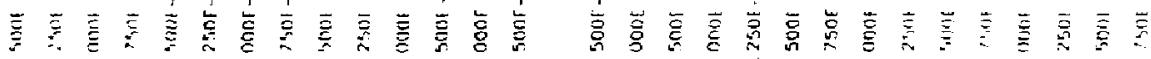

Figure 37. Isotherms for the "best model" analysis at about $3 \mathrm{yr}$ after emplacement. 
NNWSTB(3PWR 4BWR) INCOLOY 825 CON/10YR-1.73:1 SCPCHK CS13A 4/8/88 GLJ

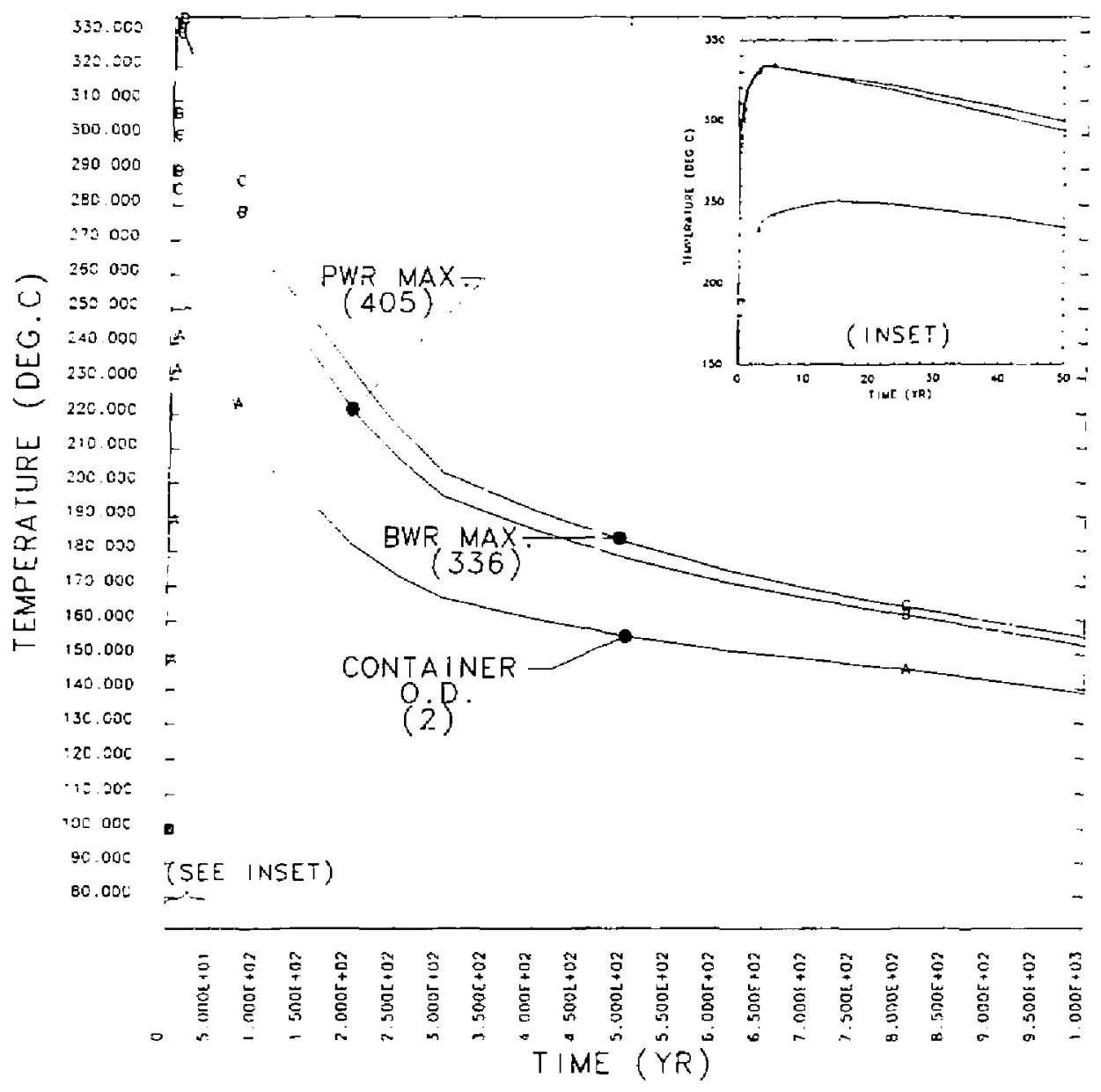

Figure 38. The peak temperature of the fuel cladding for the SCP layout case, with its $28 \%$ decrease in repository area per borehole and $15 \%$ decrease in thermal load, is $335^{\circ} \mathrm{C}$. 
NNWSI HYB(JPWR 4BWR) INCOLOY 825 CON/1OYR-1.73:1 SCPCHK CS13A 4/8/88 GLJ $T: M E=5.00000 E+00$ YEARS

-BOREHOLE WALE $=227$ DEG.E

$\operatorname{MIN}(-)=2 \cdot 43 E+02$

$3.7505-0^{\circ}=$ $\operatorname{MAX}(+)=3.35 E+02$

$3.5000^{\circ}-$

$3.250 E-C:$

$3.0005-0$.

2. $7505-0^{\circ}$

2. $5005-2$

$2.2505-0$ :

2. $0005-0$ :

1. TSOE-O

i. $5005-0$

1. 25DE-O?

i. ODOE -0 .

7. $500 \mathrm{C}-\mathrm{C2}$

5. $020[-02$

$2.5000-02$

0 .

$-2.500 E-02$

$-5.000 E-02$

$-7.50 \mathrm{aE} \longrightarrow 2$

$-1.000 E-0$ :

$-1,250 E-01$

$-1.500 E-C$

$-1.750 E-C$ :

$-2.0005-C$.

$-2.2505-01$

$-2.500 E-C^{\prime}$

$-2.7505-0$

$-3 \cdot \cos =-2$

$-3.250 E-5$

$-3.500 E-O$

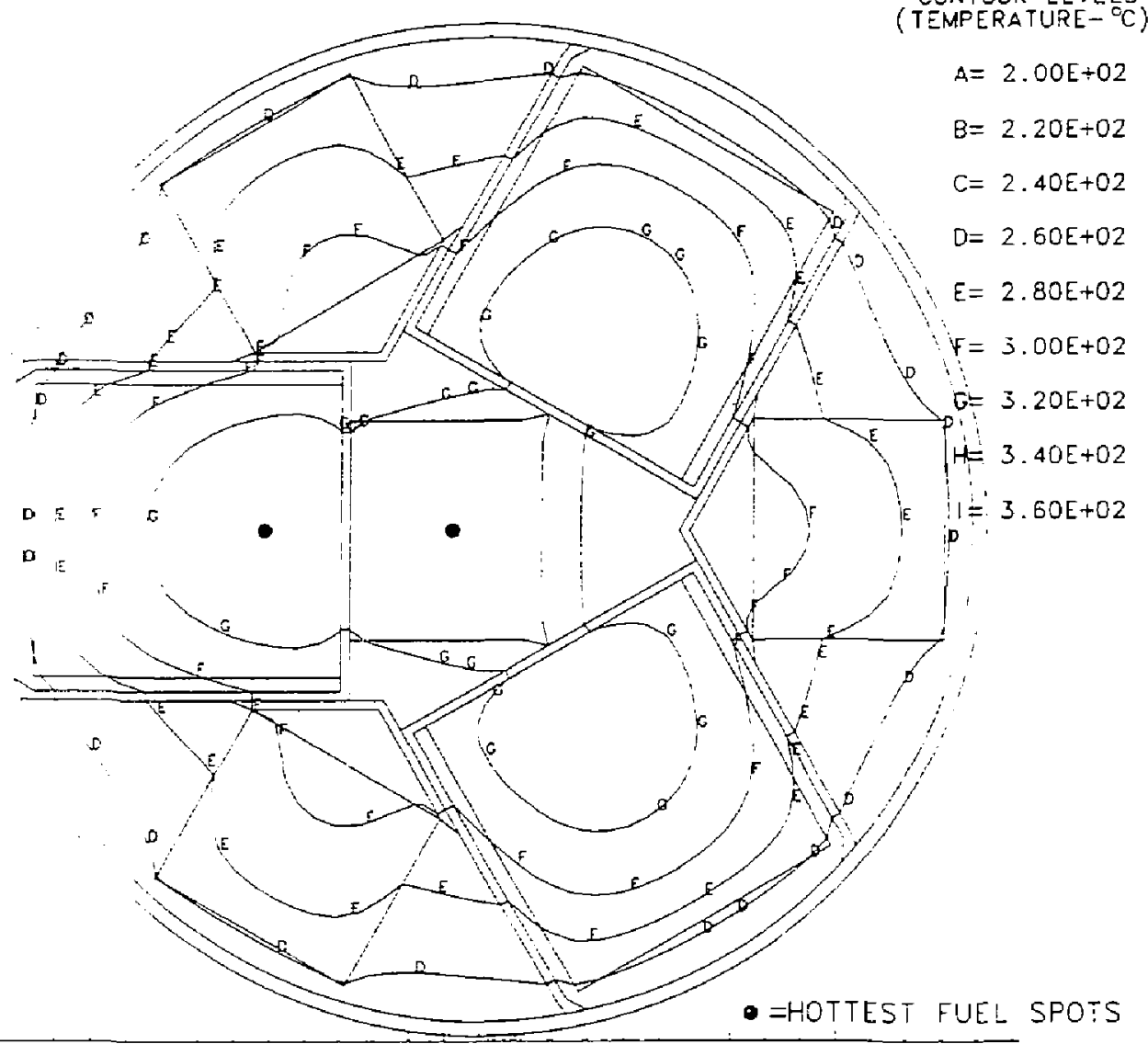

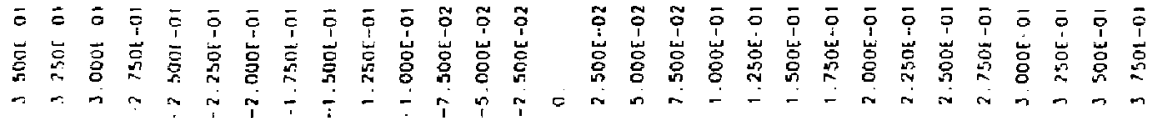

Figure 39. Isotherms for the SCP layout case at about $4 \mathrm{yr}$ after emplacement. 


\section{v. Conciusions}

The tollowing conclusions can be made from these analyses of a hybrid-filled container surrounded by an infinite array of equivalently loaded containers on $8 \times 30$ $m$ spacings. (See Figure 40 and Table 5.) For $4.75-\mathrm{kW}$ load or greater, the borehole wall stays above $970 \mathrm{C}$ for the full 1000 -yr analysis period. This load corresponds to a local power density of $80 \mathrm{~kW} / a c r e$. The tuff $1 \mathrm{~m}$ from the borehole wall never exceeds $200^{\circ} \mathrm{C}$. Because the borehole wall surface temperature nears $200^{\circ} \mathrm{C}$, it is possible that the floor of the drift tunnel near these containers might surpass the $500^{\circ} \mathrm{C}$ maximum allowable temperature set by repository manned-use requirements. For all but the the case with 5-yr-old tuel and the case with loosely packed bentonite backfiil. the peak cladding temperature remains below, but near, the $350^{\circ} \mathrm{C}$ limit. The best model thermal analysis with 10 -yr-old fuel and no backfill results in a $336^{\circ} \mathrm{C}$ peak cladding temperature occurring $3 \mathrm{yr}$ after emplacement. Thus, this thermal laad (approximately $5 \mathrm{~kW}$ ) is the largest acceptable under the defined emplacement geometry and container design constraints. Under the SCP spacing constraints, the maximum allowable would be approximately $4 \mathrm{~kW}$. Table 6 lists some other thermat load possibilities for comparison. With the peak cladding temperature nearly equal to the maximum allowable, it will be critical to evaluate the axial temperature gradients in a full 3-D model of the container before finalizing container design guidelines.

The two cases that do not satisty the cladding temperature limit requirement, 5year tuel and loosely packed backfill, result in peak cladding temperatures 40 to $60^{\circ} \mathrm{C}$ hotter than the maximum allowable. Firmly packing the bentonite in the borehole annulus results in a peak temperature of $341^{\circ} \mathrm{C}$. Because these backfill results are highly sensitive to the assumed thermal properties of the backfill, use of accurately measured values of these properties is crucial in further analyses guiding design decisions.

In addition to these specific conclusions, some general comments can be added. The small effect of the conductivity of the container assembly structural material on predicted peak cladding temperatures, its sensitivity to the value of tive surface emissivity for the surfaces inside the container, and minor effect of modeling heat conduction through (and probably even convection in) the gas fill suggests that radiative heat transier is the dominant mode inside the container. Variations in the 
"effective" thermal conductivity of the fuel rods/fuel canister is the other material parameter to which predictions of peak cladding temperatures are very sensitive. While conduction through the gas fill is small, the effect of heat transfer trom natural convection in the cavities between the fuel canisters and the containet shell may turn out to be more significant. For boreholes with no backfill, heat balance calculations on heat transterred from the container to the borehole wall also show that most of the external heat flow results from thermal radiation. Finally, analysis results show that lack of accurate values for the thermal resistances between surfaces in contact does not affect a good prediction of a peak cladding temperature.

On the basis of these conclusions and an overall view of the repository layout and expected container emplacement history, I make the following recommendations for thermal performance evaluations:

a. Establish accurate values for the effective thermal conductivity of the homogenized fuel canisters for all possible fuel packing configurations. Determine the relationship between the actual peak ciadding temperature and that predicted by the homogenized model.

b. Add natural convection in the gas fill to the internal-heat-transfer model of the vertical container.

c. Determine the suriace emissivity of the tuff and the materials to be used in the waste package designs for various expected surface conditions.

d. Eslablish more accurate values for the thermal conductivity of potentia] container backfills at various densities.

e. Using a best model, complete a 3-D analysis of the vertical containes including axial variations in power output, and material geometries, and thermal properties.

f. Do transient, 3-D thermal analysis of various combinations of emplaced packages and emplacement histories for whole sections of the repository using the planned waste delivery scenario (e.g., Ref. 2). 
g. Model the presence of ventilated drift tunnels in detail, including the dritt tunnel and its associated humidity and heat removal by ventilation.

h. Establish sensitivity of results to each of the major mocel parameters for the range of values and the uncertainty of each of these parameters. 


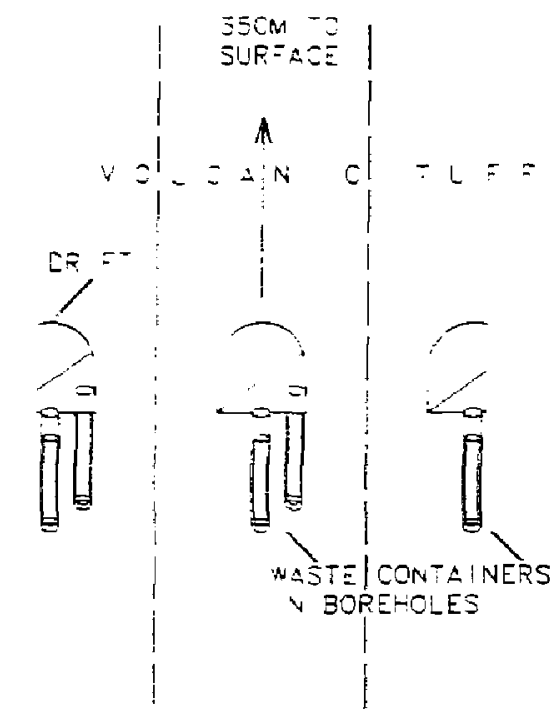

A) ACTUA REPCS PRV LAYOUT
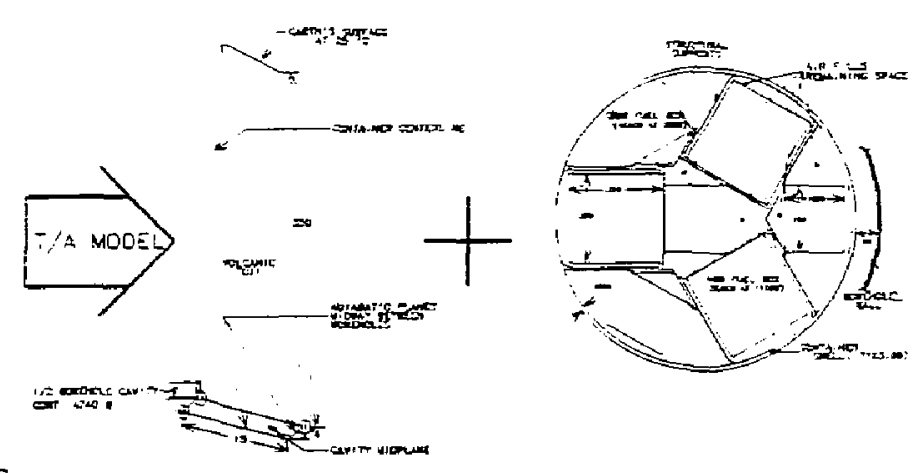

3) 3-D TUFF MODEL ANO =-O CON'A NEF MODE-

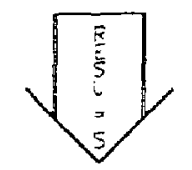

C) M VIMUM GOREHOLE TEMPERATURE ALWAYS GREATER THAN 9- DEE.

- MAXIMUN ZJEL CLADDING TEMPERATURE LESS THAN J50 DEZ $=O=T H E P M A L$ LOADS LESS THAN $474 O W$

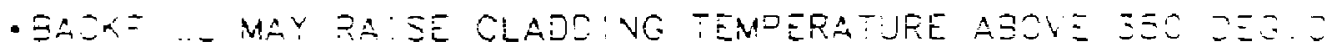

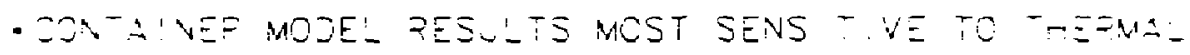
テAニAT OV OAFAME-EPS

Figure 40. The best model thermal analysis of the container shows that the hybrid-loaded container satisfies the thermal design criteria. 


\section{REFERENCES}

1. Nuclear Waste Pollcy Act (Saction 113), Site Characteristic Plan, Yucea Mountaln Site, Nevada Research and Development Area, Nevada, Volume III, U. S. Department of Energy, Office of Civiiian Radioactive Waste Management, DOE/RW-0160, 1988. HOO.881201.0002

2. DOE (U.S. Depanment of Energy), Generic Requirements in a Mined Geologic Disposal System, DOE/NE/44301-1, Wasnington, D.C.. 1984. NNA.870519.0102

3. J.R. Schornhorst et al., Conceptual Waste Peckage Designs for Disposal of Nuciear : Jaste in Tutf, Westinghouse Electic Corp.. Advanced Energy Systems Division, Rept. No. ONW/-439, 1983. SRX.830722.0035

4. W.C. ONeal et al., Nuclea: Waste Package Design for the Vadose Zone in Tuff, Lawrence Livermore National Laboratory, UCRL-89830. 1984. SRX.841102.0619

5. J.N. Hockman and W.C. O'Neal, Thermal Modeling of Nuclear Waste Package Designs for Disposal in Tuff. Lawrence Livermore National Laboratory, UCRL-89820, Rev.1, 1984. HQS.880517.2460

6. W. Siein, J.N. Hockman, and W.C. O'Neal. Thermol Analysis of NNWSI Conceptual Waste Package Designs, Lawrence Livermore Nailonal Laboratory, UCID-20001, 1984. SRX.840824.0391

7. W.C. O'Neal et al., Preclosure Analysis of Conceptual Weste Package Designs for a Nuclear Waste Repository in Tuff, Lawrence Livermore Nattonal Laboratory. UCRL-53595, 1984. HQS.880517.2514

3. W.E. Glassity. Reference Weste Package Environment Report. Lawrence Livermore National Laboratory, UCID-53726. 1986 HOS.880517.2445

@. O.H. Zeuch and M.J. Eatough, Reference intertace Base for the Nevada Nuclear Wasta Storage Investigations Project (DRAFT). Sandia National Laboratories. Aibuquerque, SLTR 86-5005. April 1986. NNI.881222.0048 
10. D.W. Gregg and W.C. ONeal, Initlal Specification for Nuclear Wasie Package External Dimensions and Materlals. Lawrence Livermore National Laboratory, UCID-19926, 1984. NNA.891016.0144

1: L.W. Scully, Reference Waste Emplacement Geometries. Sandia National Laboraiores, Albuquerque, Keystone Document 6310-83-1, 1983. NNA. 870321.0382

:2. Developed using the National Weste Terminal Storage Data Base-ORNL "Repository Waste Characteristics-I. Commercial LWR Spent Fuei." Oak Ridge National Laboratory, ORNLTM-9591.

13. F.C. Nimic et al., Recommended Matrix and Rock Mass Bulk, Machanical, and Thermal Properties for Thermal-Mechanical Stratigraphy of Yucca Mountain, Sandia National LaboratoryAlbuquerque, Keystone Document 6310-85-11, 1985. HOS.880517.2323

14. Memorandum from M.A. Molecke to Distribution, "Thermal Conductivity of Bentonite Backîlis," Sandia National Laboratories, Aibuquerque. December 7. i981. NNA.891016.0146

15. Aerospace Structural Metals Handbook. Volume 5 (Material $=1303$ ). : 985 .

:6. A.L. Edwards. A Compilation of Thermal Property Data for Computer Heat Conduction Calculations. Lawrence Livermore Natıra: Lasora:ory. UCRL-50589, 1968. NNA.891016.0147

17. F.J. Jelinek, Contract Report on Literature Survay, Properties and Microstructure of AISI Stainless Steel, Types 304, 204L, 316L, 321, and Incoloy 825. Battelte Columbus Laboratory. Metal ano Caramics Information Center, 1985 (I have a copy). NNA.81016.0148

-8. J.M. Cuta. D.R. Rector, and J.M. Creer. Thermal Hydraulic Analysis of Consolidated Spent PWR Fuel Rods. Battelle. Pacific Northwes: Laboratory, EPRINP-3764, i984. NNA.891016.0149 
19. J.P. Holman, Heat Transfer, 4th Edition, McGraw-Hill Book Company, New York, 1976. NNA.891016.0150

20. Memorandum from J. Kass to T.A. Nelson and G. L. Johnson, "Thermal Analysis Work for 1988," December 9, 1987. NNA.891016.0151

21. Memorandum from T.A. Nelson to Distribution. "Metal Barrier Update," December 2, 1987. NNA.891016.0152

22. Memorandum from R. Van Konynenburg to D.A. Lappa. "Hemispherical Total Emissivities of Candidate Waste Package Materials." August 4, 1987. (NOTE densities given in the memo are low by a factor of 1000.) NNA.891016.0153

23. in A. Gerhard, SLIC, An Interactive Graphic Mesh Generator. Lawrence Livermore National Laboratory, UCRL-52823, Rev. 4, 1985. NNA.891016.0154

24. W.E. Mason, Jr., TACO3D, A Threc-Dimensional Finite Element Heat Transfer Code, SAND83-8212, A.pril :983. NNA.891016.0155

25. J.O. Halquist, MAZE-An Input Generator for NIKE2D and DYNA2D. Lawrence Livermore National Laboratory, UCID-19029. Rev. 2. 1983. NNA.891016.0155

26. P.J. Burns, TACO2D, A Finite Element Heat Transfer Code. Lawrence Livermore National Laboratory, UCRL-17980. Rev. 2. 1982. HOS.880517.2629

27. A.B. Shapiro, FACET, A Radiation View Factor Computer Code for Axisymmetric, 2-D Planar, and 3-D Geometry with Shadowing. Lawrence Livermore National Laboratory, UClO-19887, 1982. NNA.891016.0157

28. F.C. Nimic et al.. Bulk Thermal and Medlum Propertles of the Tonopah Spring Member of the Paintbrush Tuff, Yucea Mountain. Nevada. Sandia National Laboratory-Albuquerque, SANDB5-762, 1987. HOS.880517.1685 
TABLE 1

SPENT FUEL UNIT THERMAL QUTPUT

BWR 10.yr- old, Normal Burnup Fuel (27500 MWD/MTIHA) $\cdots$

2:1 Consolidation at Reactor

\begin{tabular}{cc}
$\begin{array}{c}\text { Volume/canister } \\
\left(\mathrm{m}^{3}\right)\end{array}$ & $\begin{array}{c}\text { Metric ton } \\
\text { per canister }\end{array}$ \\
\hline 0.0756 & 0.3952
\end{tabular}

\begin{tabular}{ccccc}
$\begin{array}{c}\text { Time since } \\
\text { emplacement } \\
\text { (yr) }\end{array}$ & $\begin{array}{c}\text { Power } \\
\text { (W/metric ton) }\end{array}$ & $\begin{array}{c}\text { Power } \\
\text { (W/canister) }\end{array}$ & $\begin{array}{c}\text { 2-D Model } \\
\text { heat generation } \\
\text { (J/yr-m } \text { ( }^{*} \text { ) }\end{array}$ & $\begin{array}{c}\text { Normalized } \\
\text { power }\end{array}$ \\
\hline 0 & 911.0 & 360.0 & $1.5018 \mathrm{E}+11$ & 1.00000 \\
6 & 773.0 & 305.5 & $1.2743 \mathrm{E}+11$ & 0.84852 \\
8 & 741.0 & 292.8 & $1.2215 \mathrm{E}+11$ & 0.81339 \\
10 & 713.0 & 281.8 & $1.1754 \mathrm{E}+11$ & 0.78266 \\
15 & 652.0 & 257.7 & $1.0748 \mathrm{E}+11$ & 0.71570 \\
20 & 599.0 & 236.7 & $9.8744 \mathrm{E}+10$ & 0.65752 \\
30 & 511.0 & 201.9 & $8.4237 \mathrm{E}+10$ & 0.56092 \\
40 & 440.0 & 173.9 & $7.2533 \mathrm{E}+10$ & 0.48299 \\
50 & 383.0 & 151.4 & $6.3137 \mathrm{E}+10$ & 0.42042 \\
60 & 338.0 & 133.6 & $5.5719 \mathrm{E}+10$ & 0.37102 \\
70 & 300.0 & 118.6 & $4.9454 \mathrm{E}+10$ & 0.32931 \\
80 & 270.0 & 106.7 & $4.4509 \mathrm{E}+10$ & 0.29638 \\
90 & 245.0 & 96.8 & $4.0388 \mathrm{E}+10$ & 0.26894 \\
190 & 142.0 & 56.1 & $2.3408 \mathrm{E}+10$ & 0.15587 \\
290 & 114.0 & 45.0 & $1.8793 \mathrm{E}+10$ & 0.12514 \\
390 & 97.2 & 38.4 & $1.6023 \mathrm{E}+10$ & 0.10670 \\
490 & 85.0 & 33.6 & $1.4012 \mathrm{E}+10$ & 0.09330 \\
1000 & 49.9 & 19.7 & $8.2259 \mathrm{E}+09$ & 0.05477
\end{tabular}

- Reference 12

- iFor power/canister distributed in volume defined by canister cross section ar. container length]

... MWD/MTIHM=megawatt days per metnc ton-initial heavy metal 
TABLE 1 (cont'd.)

SPENT FUEL UNIT_THERMAL OUTPUT

BWR 10-yr- old, Normal Burnup Fuel (27500 MWD/MTIHM)

\section{2:1 Reactor Consolldated}

Time since

emplacement

(yr)

0

6

8

10

15

20

30

40

50

60

70

80

90

190

290

390

490

1000
3-D Model heat generation $\left(\mathrm{J} / \mathrm{yr}-\mathrm{m}^{3}\right)$

$5.4110 \mathrm{E}+09$

4. $5913 \mathrm{E}+09$

$4.4013 E+09$

$4.2350 \mathrm{E}+09$

$3.8726 \mathrm{E}+09$

$3.5578 E+09$

$3.0351 E+09$

$2.6134 E+09$

$2.2749 E+09$

$2.0076 E+09$

$1.7819 E+09$

$1.6037 \mathrm{E}+09$

$1.4552 E+09$

$8.4343 E+08$

$6.7712 E+08$

$5.7733 E+08$

$5.0487 E+08$

$2.9639 \Xi+08$

* [For power of one canister spread over whole borehole] 
TABLE 1 (cont'd.)

\section{SPENT FUEL UNIT IHERMAL OUTPUT}

PWR 10-yr- old, Normal Burnup Fuel (33000 MWD/MTIHM)

\section{2:1 Reactor Consolidated}

\begin{tabular}{cc}
$\begin{array}{c}\text { Volume/canister } \\
\left(\mathrm{m}^{3}\right)\end{array}$ & $\begin{array}{c}\text { Metric ton } \\
\text { per canister }\end{array}$ \\
\hline
\end{tabular}
0.1629
0.9649

T.- since

2-D Model"

Normalized

emplacement

Power

Power

heat generation

power (yr) (W/metric :on) (W/canister) $\left(\mathrm{J} / \mathrm{yr}-\mathrm{m}^{3}\right)$

\begin{tabular}{rrrrr}
\hline 0 & 1140.0 & 1100.0 & $2.1301 E+11$ & 1.00000 \\
6 & 949.0 & 915.7 & $1.7732 E+11$ & 0.83246 \\
8 & 908.0 & 876.1 & $1.6966 E+11$ & 0.79649 \\
$: 0$ & 871.0 & 840.4 & $1.6275 E+11$ & 0.76404 \\
$: 5$ & 791.0 & 763.2 & $1.4780 E+11$ & 0.69386 \\
20 & 723.0 & 697.6 & $1.3509 E+11$ & 0.63421 \\
30 & 612.0 & 590.5 & $1.1435 E+11$ & 0.53684 \\
40 & 525.0 & 506.6 & $9.8096 E+10$ & 0.46053 \\
50 & 455.0 & 439.0 & $8.5017 E+10$ & 0.39912 \\
60 & 398.0 & 384.0 & $7.4366 E+10$ & 0.34912 \\
70 & 353.0 & 340.6 & $6.5958 E+10$ & 0.30965 \\
80 & 316.0 & 304.9 & $5.9045 E+10$ & 0.27719 \\
90 & 286.0 & 276.0 & $5.3439 E+10$ & 0.25088 \\
190 & 160.0 & 154.4 & $2.9896 E+10$ & 0.14035 \\
290 & 126.0 & 121.6 & $2.3543 E+10$ & 0.11053 \\
390 & 108.0 & 104.2 & $2.0180 E+10$ & 0.09474 \\
490 & 93.8 & 90.5 & $1.7527 \mathrm{E}+10$ & 0.08228 \\
1000 & 54.7 & 52.8 & $1.0221 \mathrm{E}+10$ & 0.04798
\end{tabular}

- Reference 12

- $\quad$ ¡For power/canister distributed in volume defined by canister cross section and container length] 
TABLE 1 (cont'd.)

\section{SPENT FUEL UNIT THERMAL QUTPUT}

PWR 10-yr- old, Normal Burnup Fuel (33000 MWD/MTIHM)

\section{2:1 Reactor Consolidated}

Time since

emplacement

(yr)

0

6

8

10

15

20

30

40

50

60

70

80

90

190

290

390

490

1000
3-D Model heat generation" (J/yr-m $\left.\mathrm{m}^{3}\right)$

$1.6534 E+10$

1. $3763 E+10$

1. $3169 E+10$

$1.2632 E+10$

$1.1472 E+10$

$1.0486 \mathrm{E}+10$

$8.8759 E+09$

$7.6142 \mathrm{E}+09$

$6.5989 E+09$

$5.7723 E+09$

$5.1196 E+09$

$4.5830 \mathrm{E}+09$

4.1479E + 09

$2.3205 E+09$

1.8274E+09

$1.5663 E+09$

1.3604E+09

$7.9332 E+08$

- [For power of one canister spread over volume of one borehole] 
Hybrid Thermal Performance

TABLE 1 (cont'd.)

SPENT FUEL UNIT THERMAL OUTPUT

BWR 5-yr- old, Normal Burnup Fuel (27500 MWD/MTIHM)

2:1 Reactor Consolidated

Time since

emplacement

(yr)

\begin{tabular}{rrrrr}
$(y r)$ & $(W / m e t r i c t o n)$ & (W/canister) & $\left(\mathrm{J} / \mathrm{yr}-\mathrm{m}^{3}\right)$ & \\
\hline 0 & 1380.0 & 545.3 & $2.2749 \mathrm{E}+11$ & 1.00000 \\
1 & 1190.0 & 470.3 & $1.9617 \mathrm{E}+11$ & 0.86232 \\
2 & 1080.0 & 426.8 & $1.7804 \mathrm{E}+11$ & 0.78261 \\
3 & 1000.0 & 395.2 & $1.6485 \mathrm{E}+11$ & 0.72464 \\
4 & 951.0 & 375.8 & $1.5677 \mathrm{E}+11$ & 0.68913 \\
5 & 911.0 & 360.0 & $1.5018 \mathrm{E}+11$ & 0.66014 \\
11 & 773.0 & 305.5 & $1.2743 \mathrm{E}+11$ & 0.56014 \\
13 & 741.0 & 292.8 & $1.2215 \mathrm{E}+11$ & 0.53696 \\
15 & 713.0 & 281.8 & $1.1754 \mathrm{E}+11$ & 0.51667 \\
20 & 652.0 & 257.7 & $1.0748 \mathrm{E}+11$ & 0.47246 \\
25 & 599.0 & 236.7 & $9.8744 \mathrm{E}+10$ & 0.43406 \\
35 & 511.0 & 201.9 & $8.4237 \mathrm{E}+10$ & 0.37029 \\
45 & 440.0 & 173.9 & $7.2533 \mathrm{E}+10$ & 0.31884 \\
55 & 383.0 & 151.4 & $6.3137 \mathrm{E}+10$ & 0.27754 \\
65 & 338.0 & 133.6 & $5.5719 \mathrm{E}+10$ & 0.24493 \\
75 & 300.0 & 118.6 & $4.9454 \mathrm{E}+10$ & 0.21739 \\
85 & 270.0 & 105.7 & $-4.4509 \mathrm{E}+10$ & 0.19565 \\
95 & 245.0 & 96.0 & $4.0388 \mathrm{E}+10$ & 0.17754 \\
195 & 142.0 & 56.1 & $2.3408 \mathrm{E}+10$ & 0.10290 \\
295 & 114.0 & 45.0 & $1.8793 \mathrm{E}+10$ & 0.08261 \\
395 & 97.2 & 38.4 & $1.6023 \mathrm{E}+10$ & 0.07043 \\
495 & 85.0 & 33.6 & $1.4012 \mathrm{E}+10$ & 0.06159 \\
1000 & 49.9 & 19.7 & $8.2259 \mathrm{E}+09$ & 0.03616
\end{tabular}

2-D Model."

Power heat generation

Normalized

power

- Fieference 12

- :For power/canister distributed in volume defined by canister cross section and contanier length! 
TABLE 1 (cont'd.)

SPENT FUEL UNIT THERMAL OUTPUT

BWR 5-yr- old, Normal Burnup Fuel (27500 MWD/MTIHM)

\section{2:1 Reactor Consolidated}

Time since

emplaceme::

(yr)

0

1

2

3

4

5

11

13

15

20

25

35

45

55

65

75

85

95

195

295

395

495

1000
3-D Model

heat generation

$\left(\mathrm{J} / \mathrm{yr}-\mathrm{m}^{3}\right)$

8. $1967 \mathrm{E}+09$

$7.0682 E+09$

$6.4148 E+09$

$5.9396 \mathrm{E}+09$

$5.6486 E+09$

$5.4110 \mathrm{E}+09$

$4.5913 E+09$

$4.4013 E+09$

$4.2350 E+09$

$3.8726 \mathrm{E}+09$

$3.5578 \mathrm{E}+09$

$3.0351 E+09$

$2.6134 E+09$

$2.2749 E+09$

$2.0076 E+09$

1. $7819 E+09$

$1.6037 E+09$

$1.4552 E+09$

$8.4343 E+08$

$6.7712 \mathrm{E}+08$

$5.7733 E+08$

$5.0487 \mathrm{E}+08$

$2.9639 E+08$

- [For power of one canister spread over volume of one borehole] 
TABLE 1 (cont'd.)

SPENT FUEL UNIT THERMAL OUTPUT

PWR 5-yr- old, Normal Burnup Fuel (33000 MWD/MTIHRA)

\section{2:1 Reactor Consolidated}

\begin{tabular}{rrrrr}
$\begin{array}{c}\text { Time since } \\
\text { emplacement } \\
\text { (yr) }\end{array}$ & $\begin{array}{c}\text { Power } \\
\text { (W/metric ton) }\end{array}$ & $\begin{array}{c}\text { Power } \\
\text { (W/canister) }\end{array}$ & $\begin{array}{c}\text { 2-D Model } \\
\text { heat generation } \\
\left(\mathrm{J} / \mathrm{yr}-\mathrm{m}^{3}\right)\end{array}$ & $\begin{array}{c}\text { Normalized } \\
\text { power }\end{array}$ \\
\hline 0 & 1800.0 & 1736.8 & $3.3633 \mathrm{E}+11$ & 1.00000 \\
1 & 1530.0 & 1476.3 & $2.8588 \mathrm{E}+11$ & 0.85000 \\
2 & 1370.0 & 1321.9 & $2.5598 \mathrm{E}+11$ & 0.76111 \\
3 & 1270.0 & 1225.4 & $2.3730 \mathrm{E}+11$ & 0.70556 \\
4 & 1200.0 & 1157.9 & $2.2422 \mathrm{E}+11$ & 0.66667 \\
5 & 1140.0 & 1100.0 & $2.1301 \mathrm{E}+11$ & 0.63333 \\
11 & 949.0 & 915.7 & $1.7732 \mathrm{E}+11$ & 0.52722 \\
13 & 908.0 & 876.1 & $1.6966 \mathrm{E}+11$ & 0.50444 \\
15 & 871.0 & 840.4 & $1.6275 \mathrm{E}+11$ & 0.48389 \\
20 & 791.0 & 763.2 & $1.4780 \mathrm{E}+11$ & 0.43944 \\
25 & 723.0 & 697.6 & $1.3509 \mathrm{E}+11$ & 0.40167 \\
35 & 612.0 & 590.5 & $1.1435 \mathrm{E}+11$ & 0.34000 \\
45 & 525.0 & 506.6 & $9.8096 \mathrm{E}+10$ & 0.29167 \\
55 & 455.0 & 439.0 & $8.5017 \mathrm{E}+10$ & 0.25278 \\
65 & 398.0 & 384.0 & $7.4366 \mathrm{E}+10$ & 0.22111 \\
75 & 353.0 & 340.6 & $6.5958 \mathrm{E}+10$ & 0.19611 \\
85 & 316.0 & 304.9 & $5.9045 \mathrm{E}+10$ & 0.17556 \\
95 & 286.0 & 276.0 & $5.3439 \mathrm{E}+10$ & 0.15889 \\
195 & 160.0 & 154.4 & $2.9896 \mathrm{E}+10$ & 0.08889 \\
295 & 126.0 & 121.6 & $2.3543 \mathrm{E}+10$ & 0.07000 \\
395 & 108.0 & 104.2 & $2.0180 \mathrm{E}+10$ & 0.06000 \\
495 & 93.8 & 90.5 & $1.7527 \mathrm{E} ; 10$ & 0.05211 \\
1000 & 54.7 & 52.8 & $1.0221 \mathrm{E}+10$ & 0.03039
\end{tabular}

- Reference 12

-. iFor power/canister distributed in volume defined by canister cross sectron and container length]] 
TABLE 1 (cont'd.)

SPENT FUEL UNIT THERMAL QUTPUT

PWR 5-yr- old, Normal Burnup Fuel (33000 MWD/MTIHM)

\section{2:1 Reactor Consolidated}

Time since

emplacement
3-D Model heat generation

$\left(\mathrm{J} / \mathrm{yr}-\mathrm{m}^{3}\right)$

$2.6106 \mathrm{E}+10$

2. $2190 \mathrm{E}+10$

$1.9869 \mathrm{E}+10$

$1.8419 E+10$

$1.7404 \mathrm{E}+10$

$1.6534 \mathrm{E}+10$

$1.3763 E+10$

$1.3169 \mathrm{E}+10$

$1.2632 E+10$

$1.1472 E+10$

$1.0486 E+10$

$8.875 \cap E+09$

$7.6142 \mathrm{E}+09$

$6.5989 E+09$

$5.7723 \mathrm{E}+09$

$5.1196 \mathrm{~F}+09$

$4.5830 \mathrm{E}+09$

$4.1479 \mathrm{E}+09$

2. $3205 \mathrm{E}+09$

$1.8274 \mathrm{E}+09$

$1.5663 \mathrm{E}+09$

$1.3604 E+09$

$7.9332 E+08$

- [For power of one canister spread over volume of one borenole] 


\section{TABLE 2}

\section{MATERIAL THERMAL PROPERTIES}

\section{Material: TUFF'}

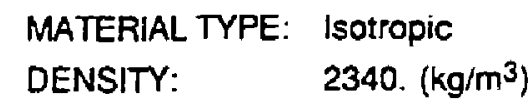

\begin{tabular}{ccc}
$\begin{array}{c}\text { CONDUCTIVi: } \\
(\mathrm{J} / \mathrm{y}-\mathrm{m}-\mathrm{m}-\mathrm{K})\end{array}$ & $\begin{array}{c}\text { HEAT CAPACITY } \\
(\mathrm{J} / \mathrm{Kg}-\mathrm{K})\end{array}$ & $\begin{array}{c}\text { TEMPERATURE } \\
(\mathrm{K})\end{array}$ \\
\hline & & \\
$6.528 \mathrm{E}+07$ & $9.615 \mathrm{E}+02$ & 273 \\
$6.528 \mathrm{E}+07$ & $9.615 \mathrm{E}+02$ & 372 \\
$6.023 \mathrm{E}+07$ & $8.034 \mathrm{E}+02$ & 373 \\
$6.023 \mathrm{E} \div 07$ & $8.034 \mathrm{E}+02$ & 773
\end{tabular}

\section{Material: BENTONITE ANNULUS back fill"*}

MATERIAL TYPE: Isotropic

DENSITY:

2000. $(\mathrm{Kg} / \mathrm{m} 3)$

\begin{tabular}{|c|c|c|}
\hline $\begin{array}{c}\text { CONDUCTIVITY } \\
(\mathrm{J} / \mathrm{yr}-\mathrm{m}-\mathrm{K})\end{array}$ & $\begin{array}{l}\text { HEAT CAPACITY } \\
(\mathrm{J} / \mathrm{Kg}-\mathrm{K})\end{array}$ & $\begin{array}{c}\text { TEMPERATURE } \\
\ldots\end{array}$ \\
\hline $\begin{array}{l}6.528 E+07 \\
2.838 E+07 \\
2.839 E+07 \\
2.113 E+07 \\
2.113 E+07\end{array}$ & $\begin{array}{l}9.615 E+02 \\
8.368 E+02 \\
8.368 E+02 \\
8.368 E+02 \\
8.368 E+02\end{array}$ & $\begin{array}{l}273 \\
273 \\
372 \\
373 \\
773\end{array}$ \\
\hline
\end{tabular}

Reference 13 (Newer data found in Feference 28)

* Reference 14 for conductivity and a density and heat capacity characteristic of cuay 
TABLE 2 (cont'd.)

\section{MATERIAL THERMAL PROPERTIES}

\section{Material: 304 STAINLESS STEEL*}

MATERIAL TYPE: Isotropic

DENSITY: $\quad$ 7940. $\left(\mathrm{Kg} / \mathrm{m}^{3}\right)$

CONDUCTIVITY HEAT CAPACITY TEMPERATURE

\begin{tabular}{ccc}
$(\mathrm{J} / \mathrm{yr}-\mathrm{m}-\mathrm{K})$ & $(\mathrm{J} / \mathrm{Kg}-\mathrm{K})$ & $(\mathrm{K})$ \\
\hline $6.528 \mathrm{E}+07$ & $9.515 \mathrm{E}+02$ & 273 \\
$4.355 \mathrm{E}+08$ & $4.89 \mathrm{E}+02$ & 250 \\
$4.671 \mathrm{E}+08$ & $5.06 \mathrm{E}+02$ & 300 \\
$5.223 \mathrm{E}+08$ & $5.30 \mathrm{E}+02$ & 400 \\
$5.718 \mathrm{E}+08$ & $5.49 \mathrm{E}+02$ & 500 \\
$6.195 \mathrm{E}+08$ & $5.65 \mathrm{E}+02$ & 600 \\
$6.659 \mathrm{E}+08$ & $5.80 \mathrm{E}+02$ & 700
\end{tabular}

\section{Material: 70/30 CUPRONICKEL"*}

MATERIAL TYPE: Isotropic

DENSITY: 8900. $\left(\mathrm{Kg} / \mathrm{m}^{3}\right)$

CONDUCTIVITY

(J/yr-m-K)

$9.240 \mathrm{E}+08$
HEAT CAPACITY $(\mathrm{J} / \mathrm{Kg}-\mathrm{K})$

$3.766 \mathrm{E}+02$
TEMPERATURE

(K)

$273-8,1$

References 15, 16, and 17

-. Reference 16 
TABLE 2 (cont'd-)

\section{ARATERIAL THEEMAL FROFEBTIES}

Material: IASCOLOY $825^{\circ}$

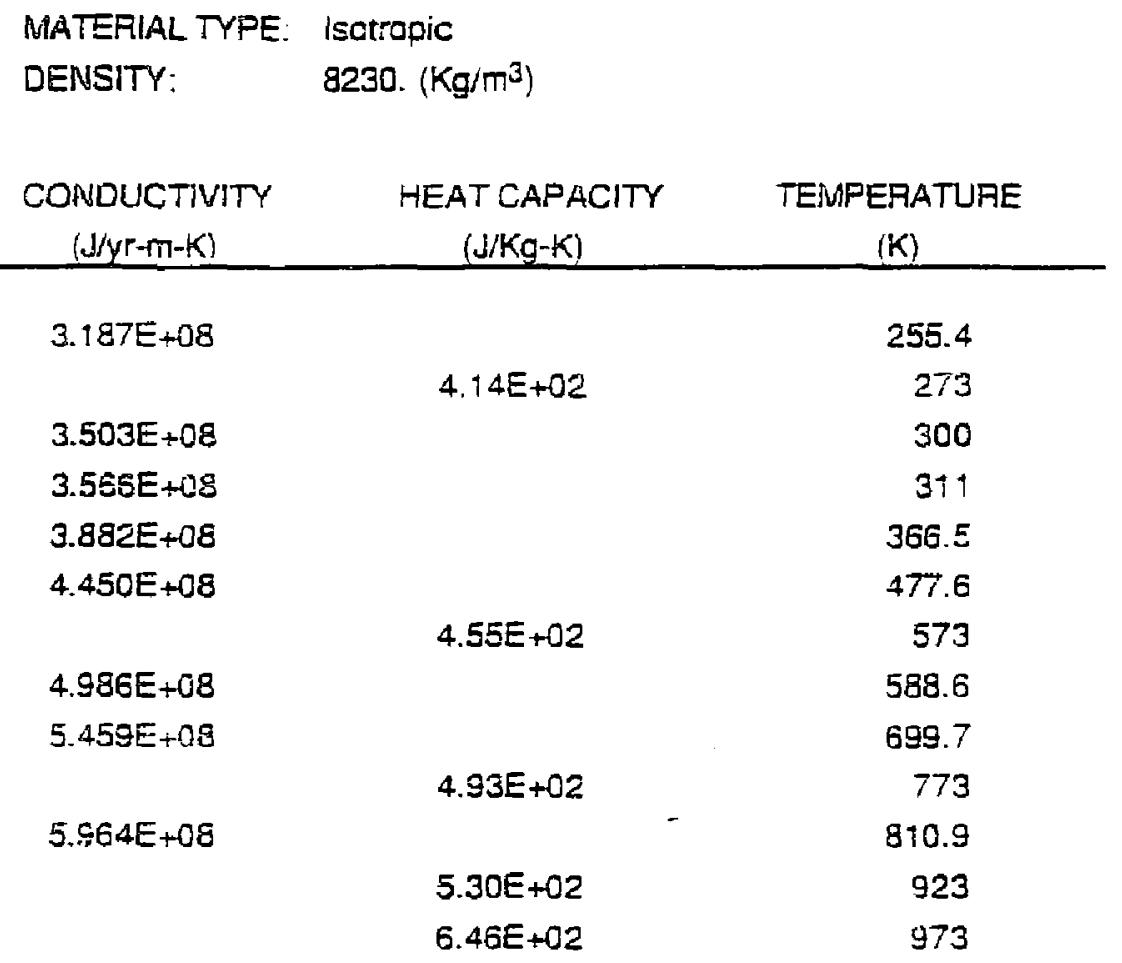

Reference 17 
TABLE 2 (cont'd.)

\section{MATERIAL THERMAL PROPERTIES}

\section{Materias: BWH \& PWF DOUBLE FACKED CANDTERS"}

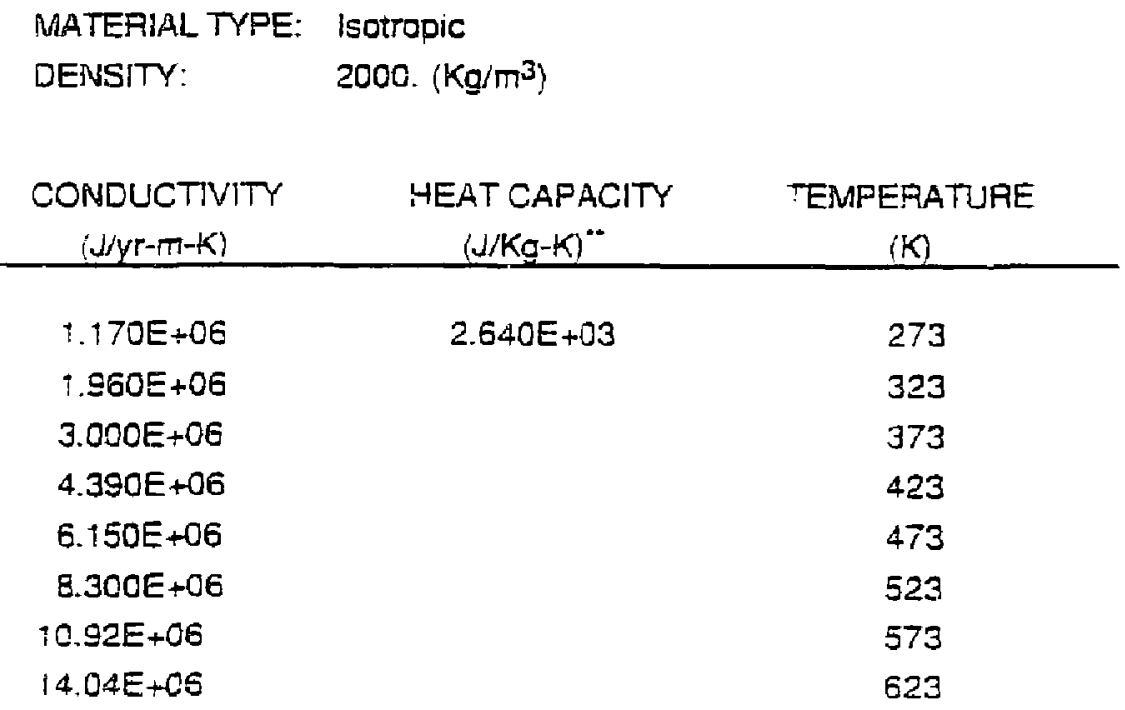

- Reference 5 ("efiective" conductivity prediction inc!. radiation and conduction modes with data curve fit to a $\mathrm{k}=\mathrm{CT}$ form about $423 \mathrm{~K}$ )

- For compansor-density times heat capacity $=5.28 \mathrm{E}+06 \mathrm{~J} / \mathrm{m}^{3}-\mathrm{K}$ for canıster clad tue! vs $1.39 E+0 E \mathrm{~J} / \mathrm{m}^{3}-\mathrm{K}$ for lust for uranium oxide fuel. 
TAERE 2 (cont'd.)

\section{MATERIAR THERMAL PROPERTIES}

Material: EGPf \& PWR DOUBLE PACKED BOXES tCase 8$]^{*}$

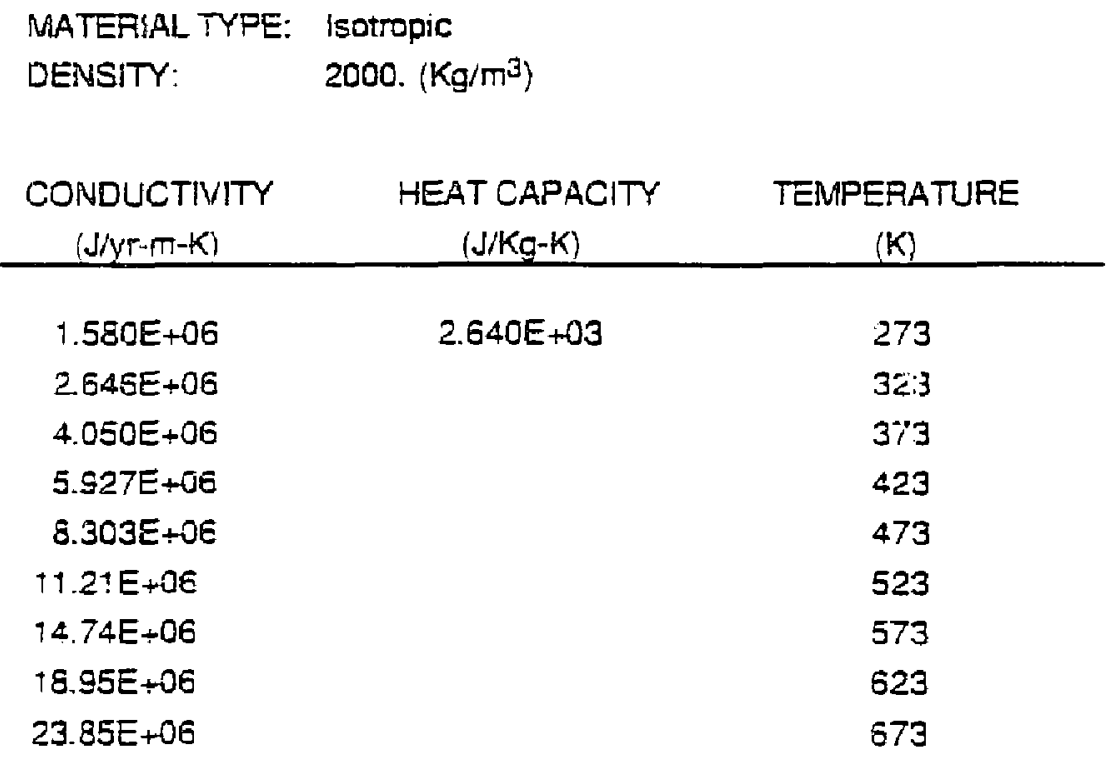

* Predictior derived trom neesured temperature profiles from Ref. 18 (themal conductivity $=i .35$ times the previous Table) 
TABRE 2 (cant'd.)

\section{MATERIAL THEFMAL PROPERTIES}

Material: Alf (a: 1 atm pressure)*

MATERIAL TYFE: Isotropic

DENSITY: $\quad$ (included with heat capacity rable)

\begin{tabular}{ccc}
$\begin{array}{c}\text { CONDUCTVITY } \\
(\mathrm{J} / \mathrm{y}-\mathrm{m}-\mathrm{K})\end{array}$ & $\begin{array}{c}\text { HEAT CAPACITY } \\
(\mathrm{J} / \mathrm{Kg}-\mathrm{K})^{* *}\end{array}$ & $\begin{array}{c}\text { TEMPEFATURE } \\
(K)\end{array}$ \\
\hline $7.023 E+05$ & 1420.3 & 250 \\
$8.275 E+05$ & 1184.1 & 300 \\
$9.470 E+05$ & $: 007.0$ & 350 \\
$10.61 E+05$ & 895.0 & 400 \\
$11.69 E+05$ & 799.5 & 450 \\
$12.73 E+05$ & 725.6 & 500 \\
$13.75 E+05$ & 567.5 & 550 \\
$14.69 E+05$ & 620.3 & 600 \\
$15.62 E+05$ & 577.5 & 650 \\
$16.49 E+05$ & 540.8 & 700 \\
$17.37 E+05$ & $51: .2$ & 750
\end{tabular}

Reierence 19 
TABLE 3A

\section{SRIN TEMPERATURES FOB "CONVECTIVE" BOUNDARY CONIDTIORS IN OPEN ANNULUS"}

(includes efiects of condietion ard convection)

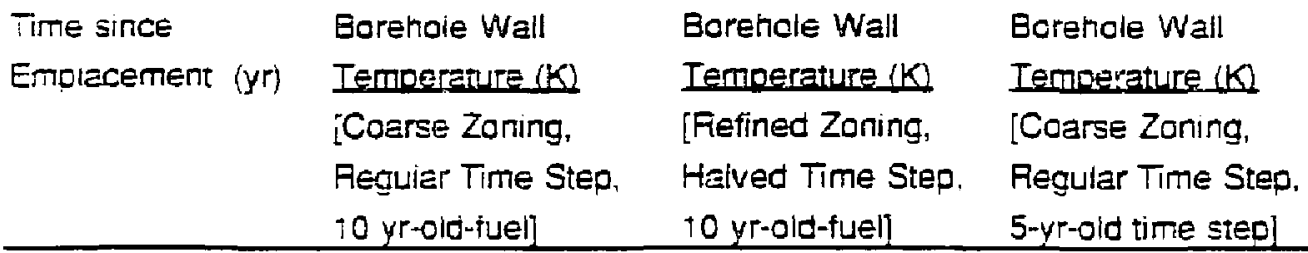

$\begin{array}{rrrr}0 . & 373.0 & 373.0 & 300.0 \\ .05 & 379.2 & 388.3 & 448.7 \\ .20 & 409.5 & 423.2 & 494.5 \\ 1.00 & 443.0 & 462.2 & 522.6 \\ 2.00 & 456.0 & 474.3 & 520.8 \\ 3.00 & 463.0 & 479.8 & 518.7 \\ 5.00 & 468.0 & 484.6 & 515.8 \\ 9.00 & 471.0 & 488.5 & 511.8 \\ 15.00 & 474.0 & 490.0 & 509.1 \\ 19.50 & 478.0 & 489.4 & 507.1 \\ 24.00 & 474.0 & 487.6 & 504.8 \\ 50.00 & 452.0 & 465.1 & 487.4 \\ 75.00 & 448.0 & 450.4 & 467.3 \\ .00 .00 & 439.0 & 440.5 & 453.5 \\ .50 .00 & 426.0 & 427.4 & 438.2 \\ 225.00 & 415.0 & 476.3 & 427.3 \\ 300.00 & 409.0 & 410.4 & 420.9 \\ 400.00 & 405.0 & 405.7 & 414.7 \\ .000 .00 & 390.4 & 389.4 & 396.3\end{array}$

- Temperatures also used for ennulus radiative heat tiansier calcs. 
TAELE 3B

\section{HEAT TRANSFER COEFFICIENT FOR "COMVECTUE" BOURADAFY CONOTIONS W OPEN ANARLLUS}

(Includes effects of conduction and convection)

Annulus Heat Transier

temperatupe Coefficient"

(K)

$\left(J / y r-m r^{2} K\right)$

$\begin{array}{ll}380 . & 8.289 E+07 \\ 400 . & 8.770 E+07 \\ 450 . & 7.966 E+07 \\ 500 . & 7.861 E+07 \\ 550 . & 7.772 E+07 \\ 600 . & 7.710 E+07 \\ 650 . & 6.301 E+07 \\ 700 . & 4.787 E+07 \\ 750 . & 3.803 E+07 \\ 800 . & 3.736 E+07 \\ 850 . & 4.020 E+07\end{array}$

- Developed using equation 7-51, Table 7.3, and Table A-6 iwater vapor) irom Reference 24. 
TABLE 4

IHEFMAL ANALYSIS CASES / 3-D FNRTE ELEMENT MODEL

\begin{tabular}{|c|c|c|c|c|}
\hline $\begin{array}{l}\text { Case } \\
\text { No. ld. }\end{array}$ & $\begin{array}{l}\text { Tuff } \\
\text { deoth }\end{array}$ & $\begin{array}{l}\text { Years-out- } \\
\text { of-reactor }\end{array}$ & $\begin{array}{c}\text { Thermal } \\
\text { load }\end{array}$ & $\begin{array}{c}\text { Other } \\
\text { model parameters }\end{array}$ \\
\hline$i=/ 3-D$ coarse mesh & $350 \mathrm{~m}$ & 10 & 4740 & $\begin{array}{l}25^{\circ} \text { e upper surface } \\
\text {-coarse mesh/step }\end{array}$ \\
\hline ib/3-D fine mesh & $350 \mathrm{~m}$ & 10 & 4740 & $\begin{array}{l}250 \mathrm{C} \text { upper surface } \\
\text {-fine mesh/step }\end{array}$ \\
\hline E/3-D 5-year fuel & $350 \mathrm{~m}$ & 5 & 7392 & $\begin{array}{l}25^{\circ} \mathrm{C} \text { upper surface } \\
\text {-fine mesh/step }\end{array}$ \\
\hline :1/3-D adiab.surface & $350 \mathrm{~m}$ & 10 & 4740 & adiab. upper surface \\
\hline :2/3-D $700 \mathrm{~m}$ depth & $700 m$ & 10 & 4740 & $25^{\circ} \mathrm{C}$ upper surtace \\
\hline 13e/3-D SCF layout & $350 \mathrm{~m}$ & 10 & 4030 & $\begin{array}{l}25^{\circ} \mathrm{C} \text { upper surface } \\
\text { SCP borehole spacing }\end{array}$ \\
\hline
\end{tabular}

THERMAL ANARYSSS CASES /2-D FINTE ELEMENT MODEL

\begin{tabular}{|c|c|c|c|c|c|}
\hline \multicolumn{2}{|c|}{ Case } & $\begin{array}{l}\text { Strucural } \\
\text { material }\end{array}$ & $\begin{array}{l}\text { Backiill } \\
\text { material }\end{array}$ & $\begin{array}{l}\text { Thermal } \\
\text { load (W) }\end{array}$ & $\begin{array}{c}\text { Other } \\
\text { model oarameters }\end{array}$ \\
\hline 1 & $304 S S$ & 304 Staintess & None & 4740 & Histoncal model \\
\hline 2 & 7030 & 7030 Cupronickel & None & 4740 & Historical model \\
\hline $3^{*}$ & IN825 & Incolov 825 & Nane & 4740 & Historical model \\
\hline 4 & $\begin{array}{l}\text { loose } \\
\text { hackfill }\end{array}$ & Incoloy 825 & $\begin{array}{l}\text { loosely - } \\
\text { packed t }\end{array}$ & $\begin{array}{l}4740 \\
\text { ntenite }\end{array}$ & Cond. only to BHW \\
\hline 5 & comect R. & Incoloy 825 & Nome & 4740 & Real Contact Resistence \\
\hline 6 & 5 -yesr fuel & Incoloy 825 & None & 7392 & Historical Model \\
\hline 7 & entissivity & Incoloy 825 & None & 4740 & Real Surf. Emissivity \\
\hline 8 & fuel cond. & Incoidy 825 & None & 4740 & Real Fuel Conductivity \\
\hline 9 & gas corid. & Incoloy 825 & None & 4740 & Conduction through Air \\
\hline 70 & best model & Incaloy 825 & None & 4740 & Best Model Analysis \\
\hline $13 a$ & SCP layout & Incoloy 825 & None & 4080 & SCP Eorehole Spacing \\
\hline$\$ 4$ & $\begin{array}{l}\text { Finm } \\
\text { Backfill }\end{array}$ & Incaloy 825 & $\begin{array}{l}\text { firmly } \\
\text { packed }\end{array}$ & $\begin{array}{c}4740 \\
\text { ntonite }\end{array}$ & Conc. only to BHW \\
\hline
\end{tabular}

The reference cases for the 3-D and 2-D analyses, respectively 
TABLE 5

\section{IEMPERATURE RESULIS SYNOPSIS/3-D AMALYSES}

\section{Case}

id.

\begin{abstract}
No.
\end{abstract}
$1 \mathbf{a}$

3-D coarse mest"

3-0 fine mesh

3-D 5-year fuel

i $\quad$ 3-D aciab.surf.

12

$13 a$

16

6

3-D SCP layout

3-D $700 \mathrm{~m}$ depth
Min. borehole wall

temperature (1000 yr)
Maximum temperaiure

1 in into iuff from BHW" (०) $\left({ }^{\circ} \mathrm{C}\right)$

128

164

127

164

134

199

167

185

64

\section{7}

22

2

164

99

The reference cases for the 3-D analyses

-. Mosi deak near-borenole temperatures occur 15 to 20 yr after emplacertent 
TABLE 5 (cont'd.)

\section{IEMPERATURE RESULTS SYNOPSIS/2-D ANALYSES}

Case

Ne. 1 id.

$: \quad 130455$

2,7030

$3 / \mathrm{iN825^{ \circ }}$

4, loose backfill

5 , contac R.

6 / 5-year fuel

7 / emissivity

8, fuel conductivity

$\xi$, gas conduction

10 , best model

13a / SCP spacing

14 , fiाtm backfill
Peak PWR"

cladding temperature
Peak BWR"

cladding temperature

(o)

(OC)

313

304

323

391

383

336

323

411

399

346

339

322

$3 \uparrow 5$

335

322

336

334

335

334

341

- The reterence case for the 2-D analyses

- Most peak cladding temperatures occur 3 to 5 yr after emplacement. 
TABLE 6

\section{THERMAL LOADS FROM POSSIBLE CONTAINER COVITENTS}

\begin{tabular}{|c|c|c|c|c|c|}
\hline $\begin{array}{l}\text { No.BWP } \\
\text { Canister }\end{array}$ & $\begin{array}{l}\text { No.FWR } \\
\text { canister }\end{array}$ & $\begin{array}{l}\text { Years-out- } \\
\text { of-reactor }\end{array}$ & Burnup & Consolidation & $\begin{array}{l}\text { Thermal } \\
\text { load (W) }\end{array}$ \\
\hline 4 & 3 & 10 & Normal & $2: 1$ & 4740 \\
\hline 4 & 3 & 5 & Normal & $2: 1$ & 7392 \\
\hline 4 & 3 & 5 & Nopmal & $i: i$ & 3696 \\
\hline 0 & 3 & 5 & Normal & $2: 1$ & 5210 \\
\hline 7 & 0 & 5 & Normal & $2: 1$ & 3815 \\
\hline 4 & 3 & 10 & Extended & $1: 1$ & 4579 \\
\hline 0 & 3 & 5 & Extended & $1: 1$ & 5268 \\
\hline 6 & 0 & 5 & Extencted & $2: 1$ & 4837 \\
\hline
\end{tabular}




\section{APPENDIX A}

Bibliography of Additional UNL Imiemal Documents on Thermal Analysis of Container Design and Emplacement

(Copies available from G.L Johnson, UNL)

1. W. Stein, Three-Dimensional Themal Analysis of a Conceptual Waste Package Design for the Disposal of Pressurized Water Reactor Spent Fue!, Unpublished Report, Lawrence Livermore National Laboratory, TF85-61, March 1985.

2. W. Stein, "Thermal Analysis of Common Canister Spent Fuel Waste Package Design," Internal Report-Themo-fluids Group, Nuclear Test Engineering Division. Lawrence Livemore National Laboratory, TF85-61, 20 September 1985.

3. Memo from W. Stein to E. Russell, "Thermal Conductivity of Spent Fuet Arrays, Thermo-fluids Group. Nuclear Test Engyneering Division, Lawrence Livermore National Laboratory, 13 June 1985.

4. Memo from W. Stein to E. Russell, Maximum Spent Fuel Container Wall Temperzture," Thermo-fluids Group, Nudear Test Engineering Division. Lawrence Livermore National Laboratory, 30 April 1986.

5. Memo from W. Stein to E. Russell, "Disposal Comtainer Temperature History For Use in Corrosion Analysis," Thermo-fluids Group. Nuclear Test Engineering Division, Lawrence Livermore National Laboratory, 14 May 1986.

6. Meno from W. Stein to T. Nelson, "Thermal Analysis of Waster !solation Containep (Hybrid Requiremenis)," Thermo-fluids Grolp, Nuclear Test Engineering Division, Lawrence Livermore National Labcratory, 4 September 1987.

7. D. Mortan, Thermal Calculations Pertaining to Experiments in the Yucca Mcuntain Exploratory Shaft, Lawrence Livermore National Laboratory, UCID-20780, 1986.

8. D. Monten. Thermal Calculations Pertaining to a Proposed Yucca Mountain Nuclear Waste Repository, Lawrence Liyermore National Laboratory, UCID in preparation, to be published 1988 . 
The following number is for Office of Civilian Radioactive Waste Management Records Managenent purposes only and should not be used when ordering this document: 


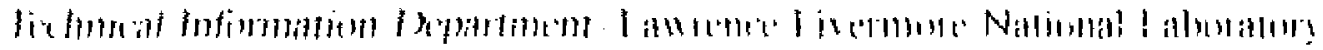

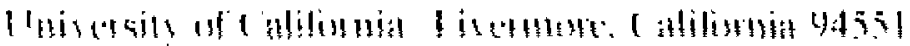

